\title{
Health and the Economy in the United States, from 1750 to the Present
}

\author{
Dora Costa \\ UCLA and NBER
}

\begin{abstract}
I discuss the health transition in the United States, bringing new data to bear on health indicators, and investigating the changing relationship between health, income, and the environment. I argue that scientific advances played an outsize role and that health improvements were largest among the poor. Health improvements were not a precondition for modern economic growth. The gains to health are largest when the economy has moved from "brawn" to "brains" because this is when the wage returns to education are high, leading the healthy to obtain more education. More education may improve use of health knowledge, producing a virtuous cycle.
\end{abstract}

Between the end of the nineteenth and the beginning of the twentieth century today's developed countries began the transition from a world in which childhood deaths and infectious disease were common to one in which childhood deaths are rare and chronic diseases are prevalent. A white American ten-year old boy born in the early 1880 s could expect to live to age 48 and to grow to $169 \mathrm{~cm}$, a short, stunted life compared to that of his counterparts born at the time of the American Revolution or after the 1920s (see Panel A of Figure 1). He began life in a country which had witnessed three major cholera epidemics, widespread malaria in the midwest, the rise of typhoid fever as newly constructed sewers poured their contents into the rivers and lakes from which towns drew their drinking water, and regulations mandating a privy for every 20 people and banning adulterated milk from cows fed on distillery wastes. He witnessed the chlorination of the water supply, the pasteurization of milk, the quarantining of all measles cases, vaccination campaigns, and the discovery of the first antibiotics. His children and grandchildren saw the elimination of smallpox and polio, the rise of smoking and its decline in response to the Surgeon General's Report, pacemakers, open heart surgery, angioplasties, and clot-busting and recombinant DNA drugs. Not all of the world has been as lucky. The Middle East and Africa still suffer from polio outbreaks. In India, where over half of the population defecates in the open, typhoid is endemic, $43 \%$ of children below age 5 are stunted and 56 out 1000 children die before age $5 .^{1}$

\footnotetext{
*I thank Hoyt Bleakley, John Brown, Matthew Kahn, the participants at a joint CCPR and von Gremp miniconference and five anonymous referees for comments. I gratefully acknowledge the support of NIH grants R01 AG19637 and P01 AG10120 and the use of facilities and resources at the California Center for Population Research, UCLA, which is supported in part by NICDH grant R24HD041022

${ }^{1}$ See http://www.unicef.org/india/wes.html and the country profiles at http://www.who.int/gho/countries/en/index.html\#N, updated May 2013.
} 
What are the lessons, if any, from the past about the health transition? This review will discuss theories of the health transition and examine how the health transition occurred in the United States and how different indicators of health, not just mortality and height, changed. It will examine changes in the distribution of health by socioeconomic status and the roles in the health transition played by rising incomes and by scientific advances and their application. In addition to reviewing the existing literature, I will bring new data to bear for some of the health indicators. The review will investigate how scientific advances were implemented. The review also will examine the implications of improvements in health improvements for economic growth. Concurrent with the increase in life expectancy and height since the 1880s, years of education almost doubled and real GDP per capita rose more than six-fold over one hundred years (see Panel B of Figure 1). I will focus on the United States both because of the availability of extensive microdata and because variation in health across both space and time - population health declined prior to the modern health improvement, helps identify the causes of the health transition.

Sanitation, medicine, nutrition, income, and fertility all affect health (see the schematic in Panel B of Figure 1). The relative roles of these factors, particularly the first four, in the health transition have been debated widely (e.g. Preston 1975; McKeown 1976; Easterlin 1996; Floud et al. 2011; Deaton 2013). This review will argue that scientific advances and their practical application, both in the past and more recently, played an outsized role. Of course scientific advances could not have been possible without rising incomes because investment in science requires a certain level of income. A certain level of income is also necessary to buy sufficient food and shelter. A review of evidence from microdata will highlight the importance of both the disease environment and of income early in the twentieth century. In contrast, the impact of exogenous changes in income on health is limited in recent times. Together, the trend and micro data imply that unhealthy conditions can outweigh the positive effects of income (as seen in Figure 1 for the 1830s to the 1880s), healthy conditions can outweigh the negative effects of income declines (e.g. during the Great Depression), and rising incomes may have little effect on health (e.g. the recent slow down in the heights at a time of rising incomes).

Both researchers and policy makers have pointed to health as spurring economic growth both in the past and today (e.g., Fogel 1994; Gallup and Sachs 2001; WHO 2001; Bloom and Canning 2005). Health affects GDP directly through productivity gains and indirectly through educational gains. Unless fertility increases outweigh these productivity and educational gains, per capita GDP will grow (see the schematic in Panel B of Figure 1). This review will argue that while improvements in health have undoubtedly raised productivity, these improvements are not a precondition for modern economic growth. The wage returns to health in the US past were low, suggesting that the nature of the economy in which health improvements occur matters. Healthier workers are both stronger and better educated workers. In the non-mechanized, low education economies of the past where physical strength was of value, the healthiest children may have sorted into unskilled occupations because the opportunity cost of education was high. The economic gains from health thus come from better ditch-digging but not necessarily from changes that push forward the technological frontier. If in today's human capital economies the healthiest children now have an advantage in learning the advanced concepts taught at higher educational levels, the 
marginal benefit of schooling will be rising at higher educational levels and the healthiest children will sort into high human capital occupations. Marginal improvements in childhood health thus can have big effects on educational attainment in a brain based economy.

Health may have a limited impact on economic growth if health improvements are costly. The early applications of scientific advances took the form of large and expensive public health works projects, such as investments in clean water. Fear of infection from the immigrant and migrant hordes crowding into cities provided the political support for financing these projects (Troesken 2004: 135). More recent applications of scientific advances have taken the form of health recommendations and therapies targeted to chronic disease. Because there are no longer any spillover effects to treating the poor, political support for programs benefitting the poor is now likely to be lower. The educated, whether because of education per se or because of characteristics such as self-discipline and patience associated with education, can better utilize the new health knowledge and maintain medical regimes, thus reinforcing at adult ages the effects of early life health on educational attainment.

This review will begin with a discussion of theories of the health transition, the relationship between health and economic growth, and economic models of health. I will then present evidence on long-run health trends, including trends in health by socioeconomic status. A review of the micro evidence will examine the changing relationship between health, the environment and income and between health and productivity. I also will review our limited knowledge of the impact of health on fertility, stressing that the effect depends on education. I will then examine how expenditures on health and political support for these expenditures has changed and how health should be valued. I will conclude with some thoughts for future research.

\section{Theories of the Health Transition}

Theories of the health transition, i.e. the increase in life span accompanied by a decline infectious disease mortality, are macro theories which emphasize aggregate changes. This section will review these theories and their implications for economic growth. It will also review the growing body of biomedical research which emphasizes the longitudinal and intergenerational effects of health and micro theories of health based on individual behavior. Although these theories are not explicitly about the health transition, they have implications for the health transition.

\section{Macro Theories}

Theories of the health transition variously have emphasized the roles of science and technology and of rising incomes and improved nutritional intake. McKeown (1976;1981) pointed out that the decline in tuberculosis mortality occurred before the availability of effective drug therapies, thus suggesting that improved nutrition was a key factor. In contrast, Preston (1975) emphasized the role of public health initiatives, showing that the curve relating life expectancy to income has been shifting upward over time. He interpreted movements along the curve, which is steep at low income levels and flatter at high income levels, as indicative of the contribution of rising living standards to life expectancy, thus 
giving the curve a causal interpretation. He interpreted the upward shift of the curve and changes in its slope as indicative of the contribution of scientific and medical knowledge and their practical implementation. He argued that over three-quarters of the increase in life expectancy between the 1930s and the 1960s came from scientific advances and their application. A large body of literature provides evidence on the historical importance of such public health initiatives as cleaning up the water supply (Cutler and Miller 2005; Troesken 2004) or eradicating hookworm and malaria (Bleakley 2007; 2010b). But there is also evidence for the role of income. In a cross-section of poor, high mortality countries disease and food availability, as proxied by income, both matter for adult health (Bozzoli, Deaton, and Quintana-Dominique 2009), suggesting that prior to the 1880s income may have played an important role.

Cutler, Deaton, and Lleras-Muney (2006) argue that the history of mortality reduction from the mid- $18^{\text {th }}$ century to the present encompasses three phases. They acknowledge that during the first phase, from the middle of the $18^{\text {th }}$ century to the middle of the $19^{\text {th }}$ century, improved nutrition and economic growth may have played a large role in health. They argue that in the second phase in the closing decades of the $19^{\text {th }}$ century and into the early years of the $20^{\text {th }}$ century public health mattered more - first negatively, because of high mortality in cities, then positively in the delivery of clean water and the removal of wastes. They label the third phase, dating from the 1930s on, as the era of big medicine, starting with vaccinations and antibiotics, and moving to the expensive and intensive personal surgical and pharmaceutical targeted at chronic disease.

Preston's emphasis on the role of scientific advances has been echoed in work by Easterlin (1996) and Deaton (2013). Deaton (2013) points out that investing in and applying new scientific knowledge requires both income and state capacity. Public health expenditures require both large financial outlays and local government employees to inspect, enforce, and teach how to avoid germs and how to care properly for babies. Following Szreter (1988), Deaton (2013) argues that broad political support, which is more likely if the poor have a political voice, is needed to implement scientific advances in the form of public health investments.

Easterlin (1996), examining the links between the mortality transition and economic growth, concluded that while modern economic growth and the rapid decline in mortality stem from the same root causes, that is, the explosion of science and technology in the last three centuries, the mortality revolution was not due to economic growth. It was instead due to public health interventions that were dependent on scientific knowledge and techniques and on government action to overcome information failures, externalities, and principal-agent and free rider problems. He discounted the role of free market institutions (Easterlin 1999) even though privately owned water companies were more likely to invest in filtration than publicly owned companies (Troesken 1999). ${ }^{2}$ Easterlin (1996) added that it is easier to achieve a mortality revolution than it is to achieve modern economic growth because controlling infectious disease demands fewer institutional, physical capital, and educational

\footnotetext{
${ }^{2}$ The fraction of US water companies with filters n 1899 was an unimpressive $19 \%$ for private companies and $6 \%$ for public companies (Troesken 1999).
} 
requirements. Controlling one infectious disease even can lead to declines in other diseases because complementarities increase health investments (Dow, Philipson, and Sala-i-Martin 1999).

Fogel's theory of technophysio evolution emphasizes the relationship between improvements in health and economic growth (Costa and Fogel 1997; Floud et al. 2011). Adjustments to adverse conditions including a limited food supply, do not occur through crisis mortality but, rather, through chronic starvation producing a thin, stunted population. The Bastille, according to Fogel's memorable image, was stormed by underweight Lilliputians. The relationship between health and economic growth is an intergenerational one. One cannot give a grown man food and expect him to be as healthy as someone who had been well-fed his entire life. Nutritional status (a function of both nutritional intake and the demands made on that intake by disease, work, climate, and other factors) determines longevity and current work levels. ${ }^{3}$ Work levels and intensity plus technology determine output. Output in turn determines living standards and technological investments. The standard of living in turn determines the nutritional status of the next generation. As a resident of London's East End at the turn of the $20^{\text {th }}$ century put it, "Look at my scrawny arm, will you ... Not enough to eat, that's what's the matter with it. Oh, not now. I have what I want to eat these days. But it's too late. It can't make up for what I didn't have to eat when I was a kiddy" (London 1903).

\section{Health and Economic Growth}

Fogel estimates that improvements in nutritional status account for at least $20 \%$ and up to 30\% of British economic growth between 1800 and 2000 (Fogel 1994; Floud et al. 2011: 125-133). These increases came both from bringing the stunted and wasted beggars and paupers into the labor force and from improving the health of those already in the labor force. ${ }^{4}$ Of course, improvements in nutritional status may not translate into the technological innovations that lead to economic growth. England at the time of the Industial Revolution had many other advantages as well and there are many examples of poor but healthy populations, including the Plains Indians (Steckel and Prince 2001), the Irish in prefamine times (Nicholas and Steckel 1997), and the Scots relative to the English in the second half of the 1700s and the first half of the 1800s (Floud et al.1990: 202-204).

Improvements in nutritional status or health may not even lead to increases in education, which is widely viewed as a key determinant of economic growth in general and of twentieth century US economic growth in particular (Goldin and Katz 2008; Acemoglu and

\footnotetext{
${ }^{3}$ The distinction between nutritional status and nutritional intake is often lost in critiques of Fogel's view (e.g. Deaton 2006; Cutler, Deaton, and Lleras-Muney 2006) which associate Fogel's view with nutritional intake.

${ }^{4}$ This back-of-the-envelope calculation is often cited and often disputed. Various scholars have questioned the estimates of caloric availability in Britain circa 1800. Harris, Floud, and Song (2014) summarize this lively debate and conclude that the optimistic estimates of British caloric availability are based on rosy assumptions about the amount of land in cultivation, the number of animals produced for food, and the amount of food lost in production processes. However, other factors are likely to bias the calculation upward. As acknowledged in Floud et al. (2011: 217), assuming that everyone above the caloric threshold is in the labor force will bias upward the actual labor force participation rate. The estimated gains of improving the health of those already in the labor force is also likely to be upward biased. This estimate is based on a present discounted value of earnings calculation which estimates the increase in earnings from increases in height and weight from a regression relating the value of slaves to height and weight. Because slaves had no work choices, the value of height and weight is likely to be overestimated. Because the need to maintain control over slaves skewed their skill accumulation, the increase in the peak of the age-earnings profile may also be over-estimated.
} 
Autor 2012). In the 19th century economy where, prior to widespread mechanization, brawn relative to brain must have been of greater relative value, improvements in child health could even have raised the opportunity cost of schooling, particularly for adolescents, thus reducing the optimal time spent in school. Bleakley et al. (forthcoming) point out that health could affect income through three distinct channels: 1) unskilled workers are more productive if they are healthier because they are stronger and better able to do physically demanding jobs; 2) healthier students learn more from the time they spend in school; and 3) better health may motivate a student to spend more time in school. Because a healthier child is more productive either because he is stronger or because he learns more during time spent in school, his opportunity cost of schooling is high. In the $19^{\text {th }}$ century, when formal education was often not a job requirement, improvements in health may have increased the marginal cost of schooling. In contrast, in the $20^{\text {th }}$ century, when wage returns to education are high, if healthier students have a large advantage in learning the advanced concepts taught at higher educational levels, the marginal benefit of schooling is rising at higher educational levels. Yamauchi (2008), Bleakley (2010), and Pitt, Rosenzweig, and Hassan (2012) present empirical examples of the ambiguity in the effect of childhood health on schooling.

The Malthusian world view has been revived in several macroeconomic studies which emphasize that mortality reductions, by increasing fertility, lead to modest or even negative output effects. For example, Acemoglu and Johnson (2007), using cross-country data, examine the effects of the sharp reduction in mortality in developing countries in the 1950s caused by the diffusion of medical technologies. They conclude that increases in life expectancy led to population increases and to smaller and statistically insignificant increases in GDP, producing a negative effect on output per capita. This is worse than the worse case produced by Ashraf, Lester, and Weil's (2009) simulation model but even their model yields relatively modest estimates. They conclude that an increase in life expectancy at birth from age 40 to 60 would raise GDP per capita by only 15 percent in the long run. Eliminating either malaria or tuberculosis in sub-Saharan Africa would raise GDP per capita by only 2 percent in the long run. These Malthusian macroeconomic studies have been criticized on several grounds. These include differences in the initial conditions faced by treatment and control group and the validity of the instrumental variables strategy, issues of how health should be measured (e.g. mortality versus morbidity) and of whether, in today's urbanized and globalized world, excess populations have the same impact as in the past (e.g. Bloom et al. 2009; Bleakley 2010a).

The modest, at best, estimates of health on GDP from macroeconomic studies stand in sharp contrast to some of the large effects of health on wages found in microeconomic studies, such as Bleakley (2010b, 2007). The macro and micro literature are not necessarily inconsistent. Even though the cohort experiencing a health improvement may benefit from higher wages, GDP per capita may not rise because of fertility effects, spillover effects leading to lower wages for other cohorts or high costs of improving health. To understand the macroeconomic effects of improvements in health we would need to know how health improvements interact with other aspects of the economy. 


\section{Micro Theories of Health}

The classic Grossman (1972) model of health treats health as both a consumption good (the healthy feel better) and as an investment good (better health leads to greater income and more time for work). The health endowment of adults deteriorates with age, with the rate of deterioration depending on health investments produced from a combination of time and purchased medical care. Individuals then solve an optimal resource allocation problem with the price of health care, their wages and their productivity in the production of health determining how resources are allocated between health capital and other goods and services.

The Grossman model implicitly underpins Mokyr and Stein's (1996) reworking of Ewbank and Preston's (1990) emphasis on the role of changing household behavior in the health transition. In this view, the germ theory of disease offered households new health production technologies; this knowledge was transmitted to households through the popular press, schools, churches, women's associations, and others impressed into the sanitary movement's cause; using this knowledge, households then made decisions given relative prices, limited resources, and environmental risk. Socioeconomic differences in health develop either because the new knowledge first diffuses to the well-to-do or because the well-to-do are more productive in applying the new technologies. However, whether changes in household behavior contributed to the health transition remains unclear, as does the extent to which household behavior changed. Mokyr and Stein's (1996) argument was theoretical, not data driven. Brown (2000), looking at correlations in a panel data set of German towns from 1889-1912, identifies higher incomes, sanitary infrastructure improvements, and lower fertility as the biggest factors behind the decline in infant mortality rates. Declining fertility and sanitary infrastructure improvements accounted for up to one-fifth and one-third of the fall in infant mortality rates, respectively. Another frequently cited behavioral factor and the target of German health campaigns, breastfeeding and other approaches to infant care, was important in explaining differences across cities and important in explaining declines in diarrheal diseases.

A drawback to the Grossman model is that it is a static model. The production function for health is fixed and known and health deteriorates much like a machine. A growing body of research which emphasizes the longitudinal and intergenerational origins of health status poses challenges to the Grossman model.

The Barker hypothesis (e.g., 1992, 1994) argues that the chronic diseases we associate with old age originate in utero or in the first year of life, either because of insults occuring during these critical periods or because of intergenerational effects that operate through the mother. Although much of Barker's evidence (e.g.,1992, 1994) is correlational, evidence on arguably exogeneous insults comes from animal studies finding intergenerational effects of maternal malnutrition during gestation through at least the second generation (Resnick and Morgane 1984; Brelser, Ellison, and Zamenhof 1975; McLeod, Goldrick, and Whyte 1972) and from cases such as the Influenza Pandemic (Almond and Mazumder 2005) and the Dutch Hunger winter (e.g., Stein et al. 2006; Painter, Roseboom, and Bleker 2005). The Dutch Hunger Winter shows that nutrition of the mother during pregnancy not only 
influences her daughter's nutrition during her fetal life but also her grandchild's birth weight (Lumey and Stein 1997).

The Barker hypothesis allows for interactions between early life insults and later life conditions. For example, in the case of non-insulin-dependent diabetes, the interaction between a poor prenatal "diet" and a rich adult diet may be important. Changes in the disease, work, and food environment (such as the move from manual to mechanized and then to sedentary labor and the increased availability of cheap food high in caloric density) occurred within a generation, potentially leading to maladaptation. Alternatively, it may be through the accumulation of insults throughout the life cycle that infectious disease leads to inflammation (e.g. Finch and Crimmins 2004).

Both the Barker hypothesis and theories of inflammation emphasize the scarring effects of insults, while other research argues that poor environmental conditions could leave very resilient survivors through positive selection effects. Models of selection posit that when mortality at younger ages is high, frailer individuals die, leaving a more robust population that survives longer. Empirical analyses, however, predominately show positive associations between debilitating events and the morbidity and mortality of adults more than 20 years after the event (e.g. Horiuchi 1983; Elo and Preston 1992; Finch and Crimmins 2004; Barker 1992, 1994; Almond and Mazumder 2005; cf. Casselli and Capocaccia 1989; Kannisto et al. 1997). Evidence of selection leaving a more robust population comes from extreme cases such as Civil War POW camps where mortality among soldiers over age 30 was greater than $50 \%$ (Costa 2012). Evidence of an exact offset between selection and scarring comes from the Chinese famine (Gørgens, Meng, and Vaithianathan 2012). In the US, scarring was probably typical. Civil War soldiers who enlisted in large cities where life expectancy at birth was roughly age 24 or 26 were shorter and faced higher old age mortality rates (Costa and Lahey 2005a).

Epigenetics, a heritable change in gene function without a change in the structure of DNA, provides a mechanism for the early life origins of disease and for transmission through both the mother and father (Pembrey 2010). Waterland and Jirtle (2003) showed that supplementing the diets of Agouti mice dams with folic acid, vitamin B12, betaine, and choline permanently affected the offspring's DNA methylation at epigenetically susceptible loci. In rats, germline epigenetic marks imposed by exposure to nicotine during pregnancy can become permanently programmed and transferred through the germline to subsequent generations, manifesting itself in asthmatic lungs (Rehan et al. 2012). Experimentally controlled dominance rank in rhesus monkeys leaves an imprint on gene regulation, probably by affecting DNA methylation levels (Tung et al. 2012). A comparison of maternal and non-maternal (including inanimate surrogate) reared monkeys shows that adverse social conditions can become embedded within the basal transcription of primate immune cells within the first four months of life (Cole et al. 2012). The Dutch Hunger Winter provides evidence for humans: those exposed to famine prenatally had less DNA methylation of the imprinted insulin like growth factor II (IGF2) gene compared with their unexposed, samesex siblings (Heijmans et al. 2008). Suggestive evidence from a remote Swedish area associates a surfeit of food in the environment when the paternal grandfather was a 9 to 12 
year-old boy (during his slow growth period) with a shortening of grandchild survival (Bygren et al. 2001).

Epigenetics also provides a mechanism for the mitigation of adverse effects. Mice with the Agouti gene are yellow and obese and face an increased susceptibility to tumors and to premature infertility. Supplementing maternal diets produced normal, brown mice (Warterland and Jirtle 2003). Maternal exposure to bisphenol A (BPA), a chemical used in the manufacture of polycarbonate plastic, alters the epigenome of offspring but the effect can be counteracted by maternal dietary supplements either of methyl donors such as folic acid or of the phytoestrogen genistein (Dolinoy, Huang, and Jirtle 2007). Future generations are not the only beneficiaries of mitigation. Regular exercise changes the genome-wide DNA methylation pattern in human skeletal muscle and adipose tissue. These epigenetic changes could contribute to altered gene expression and improved metabolism and may explain how exercise improves health (Ling and Rönn 2014).

In practice, mitigation will depend not only on self-discipline and the knowledge of how to mitigate, both areas where the well-educated may have a comparative advantage, but also on whether parents mitigate or reinforce health shocks between siblings. Equity concerns will drive parents to mitigate but the high marginal returns to investing in the healthy child will push to reinforcement. Empirical evidence is limited. There is evidence that parental early childhood inputs reinforce health outcomes at birth between siblings in the US (Datar, Kilburn, and Loughran 2010). Chinese evidence suggests that parental educational inputs reinforce the health outcomes of twins (Heckman et al. 2013; Rosenzweig and Zhang 2009), but that parental health inputs compensate for health outcomes (Heckman et al. 2013). Comparisons across socioeconomic groups using British data are also suggestive of both reinforcement and compensation: low birth weight high socioeconomic status boys are more likely to suffer adverse educational outcomes than their low socioeconomic status counterparts but high socioeconomic status mitigates the later life health effects of low birth weight among women (Currie and Hyson 1999). Empirically, in reduced form specifications, reinforcement will produce overestimates of the biological effect of health whereas mitigation will produce underestimates.

Longitudinal studies of the Dutch Hunger Winter show that either there is a long latency period for health conditions or small initial differences in health, not easily measured at young ages, become more important at older ages. Even though exposure to the famine led to low birth weights among children in utero during the third and second trimester (Stein et al. 2004), there was no effect of the famine on 18 year olds, as seen in a variety of health measures when men were examined for military service (Stein et al. 1975: 197-228). By age 59 , however, any gestational famine exposure of at least 10 weeks duration was associated with hypertension (Stein et al. 2006) and exposure to famine in early gestation was associated with more coronary heart disease, even though birth weights had been normal (Painter, Roseboom, and Bleker 2005). Parental reinforcement of initial health differences may produce large health differences at older ages and the interactions of initial health with subsequent educational and health investments may be complex. 
Heckman (2007) and Conti and Heckman (2010) provide such a framework for examining health and educational investments over the life cycle, thus reconciling the Grossman model with the intergenerational aspects of the Barker hypothesis by making self-control and conscientiousness, which determine how productive an individual is in producing health in the Grossman model, the outputs of a developmental model in which "skill begets skill." In this developmental model people possess a vector of capabilities at each age, including pure cognitive abilities such as IQ, noncognitive abilities such as patience, self-control, temperament, risk aversion, a rate of time perference and health stocks, including mortality and morbidity propensities. All capabilities are produced by investments, the environment, and genes. The capability formation process is governed by a multistage technology where each stage corresponds to a different period in the life cycle. The model allows for different inputs and technologies at different stages and for different sensitive and critical periods, that is periods where one stage is more effective and where only that stage can produce, respectively. The capabilities produced at one stage augment the capabilities attained at later stages, leading to "self-productivity." Thus higher levels of self-regulation and conscientiousness reduce health risks and avoid accidents and higher levels of health promote learning. Education in turn can have a causal effect on health. Through dynamic complementarity capabilities produced at one stage of the life cycle raise the productivity of subsequent investments. Early investment therefore needs to be followed up by later investment for the early investment to be productive. It is this dynamic process that accounts for socioeconomic differentials in health. Together, dynamic complementarity and selfproductivity imply an equity-efficiency trade-off for late child investments but not for early investments. The returns to early investments are therefore very high.

The Heckman (2007) and Conti and Heckman (2010) model has implications for the mortality transition. The cohorts that experienced the health transition, roughly those born in the first half of the twentieth century, benefited not only from public health interventions when they were young but also from investments in public education such as the" kindergarten movement" and the "high school movement" and beyond (Goldin and Katz 2008). In their old age their better cognitive and non-cognitive skills enabled them to take advantage of new medical knowledge and therapies targeted toward older adults. These cohorts began to experience a virtuous "self-productivity" cycle which should have led to improving health, but widening socioeconomic differentials, at older ages. Previous cohorts, such as those born in the nineteenth century, would have experienced less "selfproductivity" because of limited medical knowledge and therapies and because of the limited availability of schooling.

\section{Long-Run Health Trends in the US}

This section examines long-run trends in several health proxies - mortality, height, body mass index (BMI), birth weight, and chronic conditions and discusses potential explanations for the trends. The trends reveal that the US can be divided into four periods. The first period, in the 1700s and early 1800s, was one of a relatively good disease environment and high nutritional availability. More and better food, better shelter (particularly less crowding), and better geographic locations, where disease was not endemic, led to better health. The second period, from the 1830 s to the 1880 s, was one of a worsening of the disease 
environment and of nutritional availability with no new technologies to improve health. The worsening of the disease environment was starkest in urban areas. On the eve of the Civil War, New York City was "natural home of every variety of contagious disease, and the favorite resort of foreign pestilences" (Smith 1911: 19). The third period, from the 1880s to the early 1900s, saw the widespread introduction of new technologies to combat disease. The most effective technology, the provision of clean water, was a public good. Everyone was treated. In contrast, during the fourth period, from the 1930s or 1950s to the present, the new health technologies were private goods. First they were drugs to combat infectious disease and then they were therapies and health recommendations targeted at chronic conditions. The health recommendations and the new therapies, requiring both individual purchases and skills to use effectively, were complementary with income and education or correlates of education such as patience and self-discipline.

Changes in the disease environment or in relative food prices can outweigh the positive effects of income on health. During the US health declines of the 1830s to 1880s, real GDP per capita was rising (see Panel B of Figure 1). In Europe, the largest increases in heights and the sharpest decreases in infant mortality in the post-1850 periods occurred between 1913 and 1951, a period encompassing two World Wars and the Great Depression and the period of lowest growth in per capita GDP (Hatton and Bray 2010). The US time series evidence does not reveal effects of the Great Depression on health, though its effects may have been mitigated by relief programs (Fishback, Haines, and Kantor 2007) and by Old Age Assistance (Balan-Cohen 2008). One potential explanation for the absence of a Great Depression effect is that the public health investments that had already been made in the years preceeding the Great Depression such as the provision of clean water, milk, and improvements in housing protected against disease while incomes were adequate enough to secure sufficient nutritional intake and shelter. Recession effects may have been different prior to the sanitary revolution. In nineteenth century Holland, recessions increased the mortality rate later in life for most of the population, with lower social classes suffering disproportionally (van den Berg et al. 2009). Because of limited birth and death registration data, little is known about the effects of nineteenth century US recessions. Microeconomic evidence on the twentieth century finds either no effects, e.g., experiencing the Dust Bowl in utero did not affect older age disability and chronic disease rates (Cutler, Miller, and Norton 2007), or an inverse correlation between recessions and health both in recent data and data from the 1920s and 1930s (Ruhm 2000; Fishback, Haines, and Kantor 2007; Dehejia and Lleras-Muney 2004). ${ }^{5}$

Rising incomes may have played a larger role in health improvements in Europe than in the US both before and after the health transition. The US in its early history, however, was one of those fortunate places of which Malthus (1872: 252) noted, "[i]t has been universally remarked that all new colonies settled in healthy countries, where there was plenty of room and food, have constantly increased with astonishing rapidity in their population." Writing of London's East End in 1903, Jack London declared, “As a vagrant in the "Hobo" of a

${ }^{5}$ Explanations for the inverse correlation have included improvements in health behavior during a recession, selection in who gives birth during a recession, and counter-cyclical fluctuations in the quality of care, particularly in nursing homes (e.g. Stevens et al. 2011). 
California jail, I have been served better food and drink than the London workman receives in his coffee-houses; while as an American labourer I have eaten a breakfast for twelvepence such as the British labourer would not dream of eating." During the 1930s there was concern that $18-50 \%$ of surveyed British manual and even artisanal worker families did not have the resources to maintain a healthy diet (Rowntree and Lavers 1951;Crawford and Broadley 1938; Orr 1937) and an experiment with the diets of school children in Scotland in the 1920s led to those receiving a milk supplement to grow $20 \%$ more than either the control group or those receiving a biscuit supplement (Orr 1928; Leighton and Clark 1929).

\section{Life Expectancy and Mortality}

Figure 2 shows long-run trends in men's life-expectancy in the United States, patched together from different sources. The longest time series, originally put together by Fogel (1986) and continued to the present-day from Vital Statistics sources, is for life expectancy at age 10. Life expectancy at age 10 in the 1790s was high by the standards of the day, reaching almost 57 years in the early 1790s. In contrast, life expectancy at age 10 in Sweden was 46. Hacker's (2010) series (life expectancy at birth is shown in Figure 1) puts the low point during the 1860s, a period of wartime hardship. Mortality data from genealogies shows that life expectancy at age 20 declined from approximately 47 years at the beginning of the century to slightly less than 41 years in the 1850s and recovery to levels of the early 1800 s was not attained until the end of the nineteenth century (Pope 1992). Both a worsening of the disease environment, with diseases spread by increased immigration and internal migration, and rising food prices and lower food consumption resulting from a population that was growing faster than the food supply explain the decline. However, the American cohorts born in 1880-1900 were well fed, suggesting that disease and unhealthy conditions were very important just prior to the health transition (Floud et al. 2011: 331-335).

We observe the sustained twentieth century increase in life expectancy among both whites and blacks and among both men and women. Trends in women's life expectancy at birth since 1850 were similar to those of men until about 1930 when women's life expectancies began to increase more sharply (figure not shown). Since the 1970s, increases in women's life expectancies have lagged those of men. Smoking rates explain much of the deviation in life expectancy levels and trends by sex. The fraction of deaths at age 50 and older attributable to smoking was neglible for women in 1955, reached men's 1955 level in 1980 but was still relatively small at $8 \%$ and grew to $20 \%$ in 2003 , the highest fraction in all OECD countries. For men the fraction of deaths attributable to smoking was 23 and 22\%, respectively, in 1980 and 2003 (Preston, Glei, and Wilmoth 2011).

\section{Height}

The use of stature as a proxy for health in the economics literature was pioneered by economic historians in the early 1980s (e.g. Engerman, Fogel, and Trussell 1982) and is now a commonly used proxy for health, particularly in development economics. Height is a measure of net nutritional status during the growing years, including the fetal period. It depends both on nutritional intake and on nutritional demands, including those from disease, climate, and work. 
Stunting starts in utero or in early childhood (before age 3) and usually persists to give rise to a small adult. What is still unclear is whether the persistence of stunting is inevitable and permanent or whether complete catch-up can occur if conditions are conducive to it. Rat pups and piglets that were malnourished for a period shortly after birth never caught up, suggesting that stunting in humans may be permanent (Widdowson and McCance 1960).

Based on extensive studies in Guatemala, Martorell, Rivera and Kaplowitz (1990) concluded that stunting is "a condition resulting from events in early childhood and which, once present, remains for life." Although there is usually catch-up growth among adoptees, emigrants, or children treated for diseases, it often is not to the NCHS standards. Epigenetic imprinting in very early development may limit an individual's maximum height. Full catchup appears to take place at young ages but is followed by an advanced puberty and early cessation of growth (Proos, Hofvander and Tuvemo 1991).

Fogel (1986) using the abundance of military records, which recorded height as an identifier, was the first to note that the long-term trend in US white, native-born heights mirrored mortality trends. Figure 3 reproduces his data using the heights of native-born soldiers from the eighteenth through the twentieth centuries and extends the time series with the heights of white, native-born men in the last decades of this century. ${ }^{6}$ The data, which are arranged by birth cohort, show that troops who fought in the French and Indian War of the 1750s and the 1760s or who fought in the American Revolution of the 1770s nearly attained 1930s heights of $175 \mathrm{~cm}$. Cohorts born from the early 1700 s to those born in 1830 achieved a gradual increase in average stature of approximately one centimeter. Average heights fell by approximately $4 \mathrm{~cm}$ in the ensuing half century, reaching a trough among births in the $1880 \mathrm{~s}$. ${ }^{7}$ After the 1880s, American men experienced the familiar secular increase in stature of recent times, gaining approximately six centimeters by the mid-twentieth century. The secular increase in heights has been small in recent decades, rising by only half a centimeter since 1960 .

Figure 3 shows that trends in black stature, obtained from a recently collected sample of black Civil War soldiers and from recent health surveys, were similar to those of whites. The decline in black stature is consistent with Steckel's (1979) finding of a decline of two and a half to seven and half centimeters in the heights of slave children born in the two decades after 1830 .

What are health implications of height? Waaler (1984), using a sample of Norwegian males age 40-49 in 1963-79, was the first to show that mortality first declines with height to reach a minimum height close to $187 \mathrm{~cm}$ and then starts to rise. Costa (1993) found a similar functional relation between height and subsequent mortality among a sample of 322 Union Army recruits measured at ages 23-49 who lived to age 55 and were followed for 20 years. Floud et al. (2011, Figure 6.8, p. 341) found this same functional relationship among white American males age 40-59 in the 1986-1992 and among Union Army veterans measured at

\footnotetext{
${ }^{6}$ Since the sample sizes are substantial, particularly for those periods before the large wars, the major movements in the series are unlikely to represent sampling variation. In fact, the difference in average height between rejectees and those who served in the Union Army was 0.25 inches. The averages have been corrected for minimum height standards.

${ }^{7}$ No national height series is available for the end of the nineteenth century. Interpolation was based upon the assumption that the time pattern for the country followed that for Ohio.
} 
ages 40-59, both followed for 10 years. Height appears to be inversely related to heart and respiratory diseases and positively related to the hormonal cancers (Barker 1992). A caveat is that the relationship between height and subsequent mortality only shows up in large samples and is sensitive to the choice of follow-up period. Using a larger sample of Union Army recruits, I obtained suggestive evidence of a J-shaped relationship between height and mortality but the height that minimized mortality was about $10 \mathrm{~cm}$ shorter than in Waaler's Norwegian sample and the odds of death was greater at taller than at shorter heights.

BMI

Americans have grown fatter since the 1950s, but not necessarily less healthy. While obesity is associated with cardiovascular disease and type II diabetes, underweight is associated with wasting illnesses and in the past underweight was a problem. Obesity at older ages no longer kills though it still disables.

Overweight and underweight are measured by the body mass index (BMI), defined as weight in kilograms divided by the square of height in meters, which is an indicator of current nutritional status. Figure 4 shows that in the US mean BMI for white men at ages $18-19,20-24,25-29,30-34,35-39,40-49$, and 50-64 began to increase after the 1950s, with sharper increases at older ages. A similar pattern is observed among US blacks (not shown).

The US data show that in the past, a large fraction of men were underweight (a BMI of less than 18.5\%). Among men 50-64, 6\% of Union Army veterans were underweight in 1900 compared to less than $1 \%$ of men in 1988-94 (see Table 1). Even younger men were underweight: among Union Army soldiers age 25-49, 6.9\% were underweight.

Table 1 also illustrates the rising proportion of obesity from 3 percent among Union Army veterans to $13 \%$ in the 1970 s, $27 \%$ in the late 1980 s, and $38 \%$ in 2005-2010. Recent research has suggested that rising obesity levels may threaten future gains in life expectancy (Olshansky et al. 2005; Stewart, Cutler, and Rosen 2009), but these projections do not account for a changing relationship between obesity and mortality.

The relationship between weight and mortality has been changing since 1960. Mehta and Chang (2011), comparing earlier and later cohorts at ages 50-74 in three data sets, find that over time class I obese individuals (those with a BMI between 30.0 and 34.9) no longer face an elevated mortality risk relative to normal weight individuals (those with a BMI between 18.5 and 24.9) but BMI levels of 35 and over remain dangerous. The obese have experienced improvements in hypertension and cholesterol levels over the last few decades and a declining risk of dying from cardiovascular disease. However, declining relative mortality risks for the obese have not led to declining relative disability risks, as measured by functional limitations and activities of daily living, between 1988-94 and 1999-2004 (Alley and Chang 2007).

Table 2 shows that the relationship between weight and mortality has been changing at least since 1900. The table gives hazard rates from a Cox proportional hazard model of 12 year all-cause mortality for 50-64 year-old white men. Men in 1900 faced an elevated mortality 
risk from being overweight (a BMI between 25.0 and 29.9) as well as from being obese compared to men of normal weight. There was no relative mortality risk of being overweight in either 1971-1976 or 1988-1994. Mehta and Chang (2011) show that overweight individuals in the original Framingham cohort in 1948-1970 did not face an elevated mortality risk relative to individuals of normal weight, suggesting that the relationship between overweight and mortality changed between 1900 and 1960. The changing relationship between weight and mortality is greater than that documented by Floud et al. (2011: 341, Figure 6.8) for white men age 40-59, perhaps because I control for smoking. However, it is consistent with the changing relationship between weight and labor force participation rates at older ages in the United States documented by Costa (1996).

Although obesity levels in the population have risen, Tables 1 and 2, together show that the proportion of men facing an elevated mortality risk because of their weight has fallen from $25 \%$ in 1900 (those who were underweight, overweight, and obese I and II) to $13 \%$ in 19711976 (those who were underweight and obese I and II) and to 6\% in 1988-1994 (those who were underweight and obese II). We have become better at controlling the risk factors for heart disease such as cholesterol levels and high blood pressure (Gregg et al. 2005).

\section{Birth Weight}

Low birth weight is associated with significantly increased relative risk of death in the first days of life. This risk springs in part from the prematurity of many low-birth-weight infants and in part from intrauterine growth retardation. Infants that are small for gestational age because of nutritional or other deficiencies do not catch up in growth with normal infants and tend to be at greater risk of health problems throughout their lives. Barker's (1992, 1994) "fetal origins hypothesis" proposes that cardiovascular disease and non-insulindependent diabetes originate through adaptations made by the fetus when it is undernourished. Some, but not all, of these adaptations are reflected in lower birth weight. In the Dutch Hunger Winter even a normal birth weight was not a sufficient marker for good health at older ages.

The series on US birth weight trends in Figure 5 is inconsistent with the secular height and life expectancy trends, leading Floud et al. (2011, p. 340) to speculate that "the association between infant mortality and adult height was primarily related to the association between post-perinatal mortality and adult height." In developing countries adult height is positively associated with birth weight (e.g. Adair 2006; Victora et al. 2008) and the contributions of the prenatal and post-natal environment to adult height are roughly equal (Li et al. 2003; Victora et al. 2008). US white birth weights in the past were high by today's standards. Birth weights at the Philadelphia Almshouse circa 1850 were above 3500 grams and those at Boston, New York Lying-In, and Johns Hopkins were between 3400 and 3500 from the 1890s to the 1930s. Birth weights were not high because low birth weight babies were not born alive. Including still births, mean birth weights at Johns Hopkins fell to only to 3387 from $3421 \mathrm{gm}$. Birth weights after 1950 never reached such high levels. ${ }^{8}$ In contrast, black birth weights in the US were above 3200 grams only in 1950 and then fell.

High birth weights in the past are observed only at higher parities. In recent vital statistics data, mean birth weights increase by less than 100 grams for 0 parity to parities of $1-2$. In 
contrast, among whites at New York Lying-In and Johns Hopkins, birth weights increased by up 400 grams between 0 parity and parities of 1-2 and by even more for higher order parities (see Figure 6). Why birth weight rose so rapidly with parity in the past is unclear. The health or socioeconomic status of mothers is an unlikely explanation. Fathers of higher parity children were more likely to be laborers. Maternal mortality at JHU was only 0.5 percent, suggesting that any mortality selection effects would be small. Mothers of higher parity children were shorter (less than $152 \mathrm{~cm}$ tall) and as likely to have rickets. Although, controlling for age, they were less likely to have hypertension or preeclampsia, controlling for hypertension or preeclampsia does not change the coefficients on dummies for parity in a regression of birth weight on maternal characteristics. High parity children were more likely to be born alive. Stillbirths represented $12 \%$ of first births but only $7 \%$ of later births and including them in total births reduces first births by $64 \mathrm{gm}$ and later births by less. One hypothesis I cannot discount for large birth weights at higher parities is gestational diabetes which, controlling for maternal age, increases with parity. Although glucose tests were not commonly administered, a study at Boston City Hospital in 1921-24 found that $13.6 \%$ of 500 patients had glucose in their urine (Williams 1925). Variation in other contemporary studies ranged from 5 to $35 \%$ (Eastman 1946). Glycosuria is most commonly due to diabetes. In contrast to the prevalence rates at Boston City Hospital, gestational diabetes among Kaiser Permanente patients in California in 2005 was 5.3\% among non-Hispanic whites and 5.0\% among blacks, with rates increasing with the mother's age (Lawrence et al. 2008).

The birth weights of first-born white children rose between 1915 and 1968, continued to rise until 2000 and then fell (see Figure 7). The high birth weights at the Philadelphia Almshouse circa 1850 remain a puzzle. They could be due to a deliberate misreporting of parity by the mother aided by the charitable foundation (a first birth to an unwed mother may be viewed as an error but later births as a bad habit), an increase in food intake among malnourished women during the last trimester of pregnancy, or a diabetogenic effect. Explanations for improvements in birth weights from the 1910s to the late 1960s include improved nutrition (both calories and vitamin levels) and maternal health, and reduced exposures to infectious disease and environmental toxins (e.g. low-grade lead exposure is associated with preeclampsia and thus smaller babies). Some of the improvements in the prenatal environment may be a result of reductions in fertility and the concomitant move from child quantity to quality.

The pattern for African-Americans from 1968 to the present observed in Figure 7 resembles that for whites, though birth weights were lower. Causes of the recent decline in mean birth weights among both blacks and whites are still unknown but cannot be attributed to trends in maternal and neonatal characteristics, changes in obstetric practices, or concurrent decreases in gestational length (Donahue et al. 2010).

${ }^{8} \mathrm{High}$ birth weights were also observed in Montreal in the $1850 \mathrm{~s}-1870 \mathrm{~s}$ where birth weights fluctuated above 3500 gm before falling to 3100 gm by 1900 (Ward 1993: 149-150) and in three Norwegian cities where, for married women, they were above 3400 in $1860-$ 1920 (and for unmarried women up to $200 \mathrm{gm}$ lower between 1860 and 1900) and increased thereafter, reaching 3600 gm around 1980 (Rosenberg 1988). Among survivors to 1951, babies born in Hertfordshire, England between 1911 and 1939 weighed 3500 gm if they were boys and $3400 \mathrm{gm}$ if they were girls (Syddall et al. 2005). In contrast, in Vienna between 1870 and 1914 birth weights fluctuated between 3100 and 3200 grams (Ward 1993: 147), rising above 3200 grams only after 1923. 


\section{Sickness and Chronic Conditions}

Research emphasizing the longitudinal and intergenerational origins of chronic conditions predicts that infectious disease and poor diets in the past will lead to sickness and older age chronic disease. Inflammation caused by infectious disease has been implicated in arteriosclerosis (Finch and Crimmins 2004). Both low birth weight and maternal gestational diabetes is associated with hypertension in the adult children (Barker 2008; Simeoni and Barker 2009). Some scholars, however, have argued that even controlling for age average health has worsened over time because we now keep the sick alive. ${ }^{9}$ By examining military sickness trends and chronic conditions among the mothers of children born in the 1910s and 1930s, young men examined for WWII service, and older Union Army veterans, I will show that over the $20^{\text {th }}$ century as a whole, health improved and that the patterns hint at longitudinal and intergenerational effects.

The longest-running sickness series shows that the rate of admission to Army sick reports, fell from 1867 to 1970, with temporary increases during periods such as the building of the Panama Cana (see Figure 8, reproduced from Cautero 1998). Although changes in both Army standards and self-selection into the Army may have produced healthier inductees, Army mortality closely matched civilian mortality (Cautero 1998).

Evidence on chronic conditions provides snapshots in time. The mothers of children born in the 1910s and 1930s were shorter, showed signs of malnutrition, had high blood pressure during pregnancy, and were more likely to be syphilitic (see Table 3) than mothers who gave birth in the 1960s and in 1988. Five to six percent of white mothers and 14\% of black mothers in the 1910s and 1920s bore the scars of early life malnutrition. Malnutrition is measured by a flat pelvis, that is, by an external conjugate diameter of less than $18 \mathrm{~cm}$ or a conjugate diagonal less than $11 \mathrm{~cm}$. Under-nutrition during infancy, particularly lack of vitamin $\mathrm{D}$, softens the bones and reduces all pelvic dimensions. When an undernourished infant begins to stand, the pelvis becomes flattened from the pressure. The rates seen at NY Lying-In and JHU in the 1910s to 1930s are similar to rates of $4.6 \%$ for whites and $11.6 \%$ for blacks seen in 1905 at JHU (Riggs 1904). By the early 1960s (at the time of the Collaborative Perinatal Project), the incidence of flat pelvis was negligible. In Sheffield, England, the prevalence of flat pelvis fell from 10\% in 1907-16 to 3\% in 1927-30 (Martyn, Barker, and Osmond 1996) found that the prevalence of flat pelvis fell from 10\% in 190716 to $3 \%$ in 1927-30. Because flat pelvis was associated with increased risk of stroke in children at older ages, nutritional improvements are implicated in stroke declines.

Roughly $30 \%$ of both white and black mothers at JHU developed hypertension, as measured by at least one systolic reading of more than 140 or one diastolic reading of more 90 , during their pregnancies (see Table 3). The rate is similar to that of $37 \%$ found by Barker et al. (2007) in Finland in the 1920s and 1930s. In contrast, only 12-16\% of mothers were hypertensive in the 1960s and in 1988. Because blood pressure readings were taken more

\footnotetext{
${ }^{9}$ Using friendly society sickness reports, Riley (1990) argued that health has worsened over time. However, as pointed out by Harris (1999), his number of reported sick days is biased because it depends on the number of sick days paid for by friendly societies (Harris 1999). These paid sick days were limited to workers who had passed a physical exam (even though Riley compared with the recent non-institutionalized population) and generally excluded short-term illnesses.
} 
frequently in the recent data, the decline in hypertension may be understated. Higher rates of hypertension in the past were due both to higher rates of preeclampsia and to higher rates of hypertension without preeclampsia. Declining blood pressure during pregnancy implies decreasing risk of stroke, heart, and kidney disease later in life (Garovic et al. 2010).

The high rates of hypertension and malnutrition observed in mothers in the 1920s, the low birth weights of their first-born children and their suspected gestational diabetes are consistent with the high rates of hypertension among young men (predominately born in the 1920s) observed in WWII induction records (see Table 4). Among whites the prevalence of hypertension rose from $17 \%$ among men ages 18-19 to 33\% among men ages 35-37. Prevalence rates were similar for blacks. In contrast, among whites, prevalence rates for hypertension in 1988-91 were zero at ages $18-19$ and $11 \%$ at ages 35-37. Rates were higher for blacks but were less than half of the WWII rate at ages 35-37.

Information on chronic disease rates at older ages comes from comparisons of the Civil War cohort with national cohorts age 50-74 in the 1970s and onward. Tables 5 and 6, reproduced from Costa, Helmchen, and Wilson (2007) and Costa (2000), show that prevalence rates for the average combined category of decreased breath and adventitious sounds fell by $0.2 \%$ points per year for both whites and blacks between 1900 and 1910 and 1988 -1994. For men ages $50-64$ prevalence rates for musculoskeletal conditions fell by $0.5 \%$ points per year from 1910 to $1988-1994$ for black men and by $0.4 \%$ points per year for white men. Within the same age group prevalence rates for the combined category of arteriosclerosis, valvular heart disease, and congestive heart failure fell by $0.4 \%$ points from 1910 to $1976-1980$ for black men and by $0.2 \%$ points per year for white men. ${ }^{10}$ Prevalence rates for blacks were higher for almost all conditions, symptoms, and signs between 1971 and 2004. They speculate that manual labor accounted for higher rates of musculoskeletal conditions for blacks than whites whereas infectious disease explained higher rates of arteriosclerosis and heart ailments.

A drawback to the Union Army data is that ischemic heart disease was not recognized. There was no diagnostic equipment for hypertension. What is therefore unknown is whether ischemic heart disease was common, but undiagnosed, or whether ischemic heart disease replaced valvular heart disease as the most common form of heart disease and became an epidemic. By 1950 age-adjusted death rates from cardiovascular disease in the US were already close to 600 per 100,000 , peaked in the late 1960 s at roughly 650 per 100,000 and then fell sharply to reach 200 per 100,000 in the late 1990s (Mirzaei 2009).

Costa (2002), using the same Union Army data, finds that functional limitations (walking, bending, paralysis, blindness, and deafness) among the elderly declined by $0.6 \%$ per year between 1910 and the 1990s. She finds that $24 \%$ of the decline in functional limitations was due to decreases in the debilitating effects of chronic disease, $37 \%$ was due to reduced chronic disease, and the remainder was unknown.

\footnotetext{
${ }^{10}$ Floud et al. (2011: 345), reproduce the prevalence rates in Fogel (1994), which give a prevalence rate of $76 \%$ for heart disease. This high prevalence rate was derived before the detailed medical information was available and simply indicates that the heart was mentioned but does necessarily have diagnostic implications.
} 
Have disability declines accelerated in recent years? Standardizing for age, Manton, Gu, and Lamb (2006) report disability declines of $0.6 \%$ per year between $1982-84,1.1 \%$ per year between 1984-89, 1.3\% per year between 1989-94, 1.8\% per year between 1994-99, and $2.2 \%$ per year between 1999-2004/2005 among those age 65 and over. Other work finds mixed evidence for the 1980s but consistent declines from the mid and late 1990s onward on the order of 1 to $2.5 \%$ per year for difficulty with daily activities and help with daily activities (see the review by Freedman et al. 2004). Martin, Schoeni, and Andreski (2010) find differences between those age 65+ and those age 40-64. Among those age 65+ the proportion with high risk biomarkers (C-reactive protein, total cholesterol, and blood pressure) declined as did the proportion needing help with activities of daily living. The fraction reporting difficulty with at least one of nine physical functions remained unchanged. In contrast, among younger cohorts there was little change in high-risk biomarkers, no change in reporting difficulty with at least one of nine physical functions and an upward trend in the proportion reporting difficulty with activities of daily living, though this was a small number. The data raise the concern that future cohorts of elderly may not be as healthy as recent cohorts, perhaps because of rising obesity.

\section{Some International Comparisons}

Data from the European countries with long time series on life expectancy and heights illustrates that in its early history the US was an unusually healthy place to live but converged to the European pattern between the 1850s and 1880s. However, even when US heights were at their nadir circa the 1883 birth cohort, Americans were taller than the French, the British, and a full $5.2 \mathrm{~cm}$ taller than the Italians but were shorter than the Dutch, the Norwegians, and the Swedes even though those populations only achieved the height of the US cohort of 1780 after 1911 (see the times series in Hatton and Bray 2010). ${ }^{11}$ Jack London could write of London's East End, "One thing particularly conspicuous in this crowd was the shortness of stature. I, who am but of medium height, looked over the heads of nine out of ten. The natives were all short, as were the foreign sailors. There were only five or six in the crowd who could be called fairly tall, and they were Scandinavians and Americans."

In all countries consistent improvement in life expectancy and adult heights comes only after 1850, sometimes later. Prior to 1850 there were fluctuations or even reversals in life expectancy and heights. See Figures 9 and 10, which, respectively, compare male life expectancy at age 10 in the United States, Sweden, and France and men's heights in the United States, Sweden, France, Great Britain, and the Netherlands.

For Sweden, the period between 1720 and 1850, was characterized by fluctuations in life expectancy and heights brought on by wars, epidemics, and crop failures; but, the overall trend in heights and life expectancy was one of improvement. Although incomes remained low, there were periods of peace. The spread of the potato as a field crop provided a cheap source of nutrition. Public health measures included small pox vaccination campaigns and

\footnotetext{
${ }^{11}$ One difficulty in comparing trends in heights in the US and UK with those in continental Europe is that continental European heights are consistently conscript heights whereas those in the US and the UK are not. There is a height decline in the US and the UK that coincides with industrialization but there is no such decline on the continent.
} 
improvements in sanitation, hygiene, and child care spurred by government propaganda spread through churches and compulsory schools. Initial investments were made in water and sewage. After the last disastrous crop failure of 1868-69, heights and life expectancy increased almost steadily, with heights rising by almost $10 \mathrm{~cm}$ and with life expectancy at age 10 increasing by almost 10 years. Since the 1960s, the rate of growth in heights has slowed. These steady improvements in heights and life expectancy coincide with rising incomes, declining food prices between 1870 and 1914, investments in public sanitation infrastructure, and, particularly in the 1915-50 period, the expansion and improvement of publicly provided medical facilities and personnel (Sandberg and Steckel 1997).

In France, heights rose by about $2.5 \mathrm{~cm}$ for the 1800 to 1893 birth cohorts, with slightly faster growth at the beginning and end of the period and none between 1880 and 1900 . Cohorts born in the twentieth century experienced more rapid increases - heights rose by about $7.5 \mathrm{~cm}$ between the 1900 and 1978 birth cohorts. Life expectancy at age 10 declined sharply with the Franco-Prussian War and the two World Wars but the overall trend increased life expectancy at age 10 by 24 years. For nineteenth century cohorts, the relationship between per capita income and height was a linear one (Weir 1997). Weir's (1997) analysis of height differentials across French departments between 1840 and 1911 implies that rising wages explain between 44 and $63 \%$ of the height increase between those years. ${ }^{12}$ The effects of declines in crude death rates on height increases cannot be inferred because the effects of crude death rates are not robust across his specifications. Although public health investments played a large role in mortality declines within cities between 1820 and 1880, most of France was relatively rural (Weir 1997).

Floud et al. (1990: 134-163) discovered that in Great Britain the heights of 20 year-olds declined beginning with the cohort born in the 1840s and reaching a nadir roughly with the cohorts born in the 1860 s, with the exact timing depending on the age that was examined. Floud et al. (2011: 134-139) discuss the challenges to these estimates raised by other scholars on statistical grounds and on the basis of other samples such as those of convicts. On the whole there is agreement that there was a decline in the heights of British cohorts somewhere between 1820 and 1850, thought the exact timing is unclear. Although heights increased by more than $2 \mathrm{~cm}$ from 1870 to the end of the nineteenth century, there were fluctuations and the sustained increase does not come until the twentieth century when heights increased by another $7 \mathrm{~cm}$. The decline in British heights coincides with rising urbanization and all of the attendant ills of unsanitary cities and, although diets improved in second half of the nineteenth century, the sustained increase in heights came after the substantial investments in sewage and water treatment in the 1890s and early 1900s (Floud et al. 2011: 173).

The Netherlands also experienced a reversal in heights in the early 1800s. After an increase in heights for those born between 1798 and 1810, the cohorts born between 1810 and 1837 experienced a decline. The upward climb begins only after 1850. Early cohorts faced fluctuations in food prices and economic stagnation (Drukker and Tassenaar 1997). Between

\footnotetext{
${ }^{12}$ Height in mm rose from 1643.4 to 1661.1. A real wage index rose from roughly 380 to 700 . The coefficients on the logarithm of real wages ranged from 12.84 to 18.21 in a regression of height in mm on wages, crude death rates, and other factors (see Weir 1997).
} 
1870 and 1978 heights increased by almost $16 \mathrm{~cm}$, with the most rapid increases in the twentieth century, and unlike the United States, Sweden, France, or Great Britain, there is no evidence of a slow-down in height increases. For the Dutch, the timing of growth spurts in the second half of the nineteenth century coincides with changes in real wages (Jacobs and Tassenaar 2004). Starting with the cohorts born in the late 1950s, the Dutch became the tallest population. Explanations are purely speculative and include the Dutch medical system and universal health insurance, the low labor force participation rates of mothers, and a public health monitoring system in which mothers from all social classes participated (de Beer 2004).

Past European populations also were underweight, even more so than Americans. Floud et al. (2011) estimate that mean BMI for males age 20-30 was about 21 circa 1800 and was only 19 for French males circa 1785. Mean BMI among younger British men was less than 22 in the 1850s and 1860s and it was between 23 and 24 among older men. Mean BMI for older men began to increase after 1950 and for younger men to increase after 1960 (Floud 1998). Europeans remain thinner than Americans.

Overall the time series data on individual European countries suggests that increases and improvements in nutritional intake played a role in nineteenth century height increases, but the experiences of different countries varied. The twentieth century evidence points more toward public health reforms. The importance of public health reforms is emphasized by Hatton (2013) who finds that in a panel of 15 European countries from 1871 to 1980 declines in infant mortality account for 4 to $5 \mathrm{~cm}$ of the increase in height, with most of the increase coming between 1911 1955, whereas increases in income account for 1 to $2 \mathrm{~cm}$ of the height increase.

\section{Trends in Health by Socioeconomic Status}

US trends in health differentials by socioeconomic status for infant and child mortality, birth weight, height, and BMI are consistent with changes in the disease environment and with the spread of public health followed by the diffusion of personal health therapies and regimes. The low inequality in health by socioeconomic status of period one was replaced by high inequality as the disease environment worsened. The third period saw reductions in health inequality which continued until the 1950s because public health investments differentially benefited lower income individuals who could not afford to pay for clean water. In the fourth period health inequality by socioeconomic status began to rise because the new health producing technologies were private goods requiring income to purchase and education (or its correlates) to use effectively. Although socioeconomic differentials contract as a new medical innovation becomes more widespread (Goldman and Lakdawalla 2005; Chang and Lauderdale 2009), as long as new innovations become available then on average there may be no contractions.

Changes in socioeconomic health differentials coincide with changes in income inequality. The wage returns to clerks relative both to common laborers and to artisans were increasing in the 19th century (Katz and Margo forthcoming). Income inequality was high but falling at the beginning of the twentieth century, compressed sharply during the 1940s, was relatively 
stable in the 1950s and 1960s, and then rose sharply in the late 1950s reaching levels higher than those in 1939 (Goldin and Katz 2008). However, changes in income inequality are not necessarily the drivers of changes in health inequality. There are many potential pathways relating income inequality to health. One of these includes nonlinear income effects, whereby if the health of the rich is not much affected by their income but that of the poor is then transfers to the poor will improve their health (Preston 1975). Another is relative deprivation in which rank determines not just in how healthy of a location people live but also how much control they have over their lives and in their jobs, thus affecting their health through stress levels (Marmot and Wilkinson 1999). Additional arguments include credit restrictions which prevent the poor from making investments in their children's health and human capital, nutritional traps such that poor workers cannot buy the food needed to sustain their work (Ray 1998), and public goods provision, under the reasoning that more equal societies provide more public goods. Surveying the evidence, largely from developing countries but also for the US and the UK, Deaton (2003) concludes that there is little evidence that income inequality per se leads to poor population health (though it may increase homicide levels) and that research should focus on the role of low income in poor health. Thus if rising inequality coincides with income declines for the poorest, average health may worsen during periods of inequality if income effects are large only at low income levels.

Those at the bottom of the income distribution are likely to be in poor health if the causality goes from health to income and much of the evidence for adults in today's developed countries points to this. For example, using data on London civil servants, Case and Paxson (2011) find that health in adulthood is associated with future promotions but that current civil service rank is not associated with future health. Smith $(1999 ; 2004)$ finds that health shocks among the middle-aged have a relatively large negative impact on family income and wealth. However, for children in the US today, a powerful determinant of their health is their family's long-run average income, which protects child health upon the arrival of chronic conditions. The health of children from families with lower incomes erodes faster with age, and these children enter adulthood with both lower socioeconomic status and poorer health (Case, Lubotsky, and Paxson 2002).

\section{Infant and Child Mortality}

Figure 11 summarizes the twentieth century US evidence on child and infant mortality, drawn from Haines (2010). The ratio of infant mortality among the lowest relative to the highest socioeconomic status classes was very high circa 1912, became roughly equal by 1950 and then rose again, though it never reached 1912 levels. Inequality decreased between 1990 and 2000. Trends in child mortality by socioeconomic class suggest increases in inequality between 1900 and 1920. The increase in inequality between 1910 and 1920 is not necessarily inconsistent with the trend in inequality in infant mortality - no data are available on inequality in infant mortality for that period. One of the drawbacks in examining trends in infant mortality by socioeconomic status is that they magnify socioeconomic differences at low infant mortality levels. For example, if infant mortality falls from 40 to 5 per thousand among low status households and from 30 to 2 per thousand among high status households, the infant mortality ratio increases from 130 to 250 whereas 
the infant survivorship ratio increases from 99 to 100. Similar to the trend in inequality in infant mortality, infant survivorship between 1912 and 1950 became more equal, but unlike the trend in infant mortality the trend in infant survivorship since the 1960s has been almost as equal as in 1950 (see Figure 11).

Detailed data from England and Wales reveal that from 1895 to 1921 infant mortality rates fell more sharply among the upper and middle classes than among unskilled workmen, leading to rising inequality in infant survivorship (see Figure 12). ${ }^{13}$ Unusually bad years, such as 1911, produced greater reversals among lower class families (Woods 2000: 265). After 1921, inequality declined as infant mortality rates fell more among the unskilled than among the skilled. ${ }^{14}$ Because of differences in how social class is defined, infant survivorship ratios between the top and bottom social ranks in the United States and England and Wales in Figures 11 and 12 cannot be compared. Preston and Haines (1991: 185) reclassified US occupations into British occupational codes to conclude that inequality in child mortality in the US circa 1895 was less than in England and Wales in 1911. Although 1911 was an unusually bad year for the UK, it was no worse than 1895 . The US social gradient in infant mortality is now higher than in Europe because of worse outcomes among less educated mothers after the first month of life (Chen et al. 2013).

In both the United States and England and Wales, geographical differences in mortality swamped socioeconomic differences (Preston and Haines 1991; Woods 2000). However, within cities place of residence was a good indicator of socioeconomic differences. Figure 13, reproduced from Floud et al. (2011: 328, Figure 6.3), plots the maximum, mean, and minimum infant mortality rate by ward in 6 major cities in the US. Because the poor lived in the areas with the highest infant mortality rates and the rich lived in the areas with the lowest infant mortality, the figure implies that between 1900 and 1950 more than 80 percent of the difference in the infant mortality rate between the poorest and richest wards had disappeared. ${ }^{15}$

\section{Birth Weight and Weight in Infancy}

Consistent with trends in infant mortality by socioeconomic class, socioeconomic differentials in birth weight were larger in the US of the 1910s-1930s than in more recent data. Costa (1998) found that differences in birth weight between the $10^{\text {th }}$ and $90^{\text {th }}$ wage percentile at New York Lying-In in the 1910s to 1930s compared to the 1988 National Maternal and Infant Health Survey were twice at large at NY Lying-In, probably an understatement because NY-Lying In was primarily an upper working class sample and did not cover the full wage distribution. A comparison of full-term, "normal" white births at $5^{\text {th }}$

\footnotetext{
${ }^{13}$ The study of socioeconomic differentials in mortality can be carried back even further in time in England and Wales. Examining ducal and commoner life expectancy at birth (and thus including the high child mortality rates of the era) from 1541/46 to 1866/71, Harris (2004) finds that life expectancy at birth began to diverge after 1750 and by $1866 / 71$ the difference was roughly 20 years. ${ }^{14}$ Comparisons of the top and bottom social ranks have been criticized as ignoring the middle ranks, whose numbers have been rising as fewer men are in the bottom social rank. Using a summary indicator for all social classes, Pamuk (1988) argued that for legitimate births inequality rose between 1921 and 1972 and then fell from 1972 to 1980. Pamuk's summary indicator was a "slope index of inequality," i.e. the slope of the linear regression of mortality across all classes weighted for the proportion of the population in each class. This procedure effectively magnifies the effect of socioeconomic differentials at low levels of infant mortality.

${ }^{15}$ High within city differentials were also found in Paris where life expectancy at age 5 between the worst and the best neighborhoods was over 10 years in the 1890s (Rosenthal and Kesztenbaum 2012).
} 
Avenue (a hospital serving the well-to-do) in the early 1930s with charity cases at Bellevue found birth weight differences of $100 \mathrm{gm}$ among first births, but little difference in higher order births (Stewart 1943). Absolute differences between private and welfare patients in the Collaborative Perinatal Project of the 1960s were only 30 gm (see Table 7).

Inequality in birth weights by education has increased since the late 1960s. Controlling for gestational age, mother's age, sex of the child, parity, and hispanic origin, the difference in white birth weights between those with less than a high school education and those with more was less than $100 \mathrm{gm}$ in 1960, rose to a peak of 127 to $195 \mathrm{gm}$ in 1988 and then fell to a difference of 50 to $100 \mathrm{gm}$ in 2011(see Figure 14). The gradient was particularly large for college education. The educational gradient in birth weight differentials coincides with the educational gradient in maternal cigarette smoking, which peaked between 1980 and 1990 (Aizer and Stroud 2010).

Weight differentials by socioeconomic status diverged in the first year of life (see Figure 15), though the early samples were too small to determine if this was true controlling for first birth. Babies born at Bellevue in the late 1920s were well below the modern WHO $50^{\text {th }}$ weight percentile whereas those born at $5^{\text {th }}$ Avenue Hospital reached the $50^{\text {th }}$ percentile by the $25^{\text {th }}$ week. In contrast, there was little difference in the weights of babies of private and welfare patients in the 1960s. At one year of age the babies of white and black patients at Johns Hopkins University in the first third of the century had similar weights, but there may be bias in who was followed in the samples.

\section{Height and BMI}

For the cohorts born circa 1750 there were no differences in adult height by broad occupational group. Among the cohorts born in the 1820 s to 1840 s, farmers were relatively taller but there were no differences between laborers and professionals and proprietors. ${ }^{16}$ In contrast, the difference between laborers and professionals and proprietors was an inch $(2.54 \mathrm{~cm})$ for the cohorts born in the 1920s and then declined for cohorts born in the 1940s and later (Costa and Steckel 1998).

Educational differentials by height are consistent with occupational differentials by height (and also with infant mortality differentials) and suggest that inequality was low in the first half of the nineteenth century. The top panel of Figure 16 graphs the height coefficients from regressions of height on years of education in Bleakley et al. (forthcoming). There was little relation between height and education among the Civil War cohort (born in the 1820s to mid 1840s), a very strong relation between height and education among the cohort serving in World War II (born in the 1900s to mid-1920s), and then a declining relation thereafter. Because height is largely determined by age 3, Bleakley et al. (forthcoming), treat the causality as going from height to education, while acknowledging the correlational nature of the evidence. They attribute the lack of a strong relation between height and education in the $19^{\text {th }}$ century to a more brawn-based economy which led healthier children either to select

\footnotetext{
${ }^{16}$ Differences by occupational class in Britain and Ireland were larger. Among men born circa 1815, the difference between the tallest occupational group (those in commerce) and the shortest (domestics) was about half of an inch (1.3m) (see Figure 5.3 in Floud, Wachter, and Gregory 1990: 203).
} 
into manual occupations or not to stay in school longer because their time spent in school was more productive and the opportunity cost of additional schooling was high.

The bottom panel of Figure 16 shows that only among cohorts age 20-45 after the 1950s has the relationship between education and BMI become stronger. The figure graphs the coefficients from a regression of education on BMI from the Civil War cohort to present cohorts. For more recent cohorts, I also control for smoking status which magnifies the relationship between education and BMI. These data are consistent with models in which education plays an important role in determining current health.

The relationship between education and mortality at older ages has become stronger since 1900 , in part because of the educational gradient in smoking. Table 8 presents hazard ratios from Gompertz models examining 12-year mortality rates among Union Army veterans age 55-74 in 1900 and men of the same age first observed in the 1970s and the late 1980s and early 1990s. Education was not a statistically significant predictor of 12-year middle and older age mortality rates among native-born Union Army veterans. However, without controls for smoking, education was a statistically significant predictor of mortality rates in all three late $20^{\text {th }}$ century samples, and its effect may be increasing. The hazard ratios suggest that the relative risk of death for a year of education fell from 0.989 in the Union Army to 0.969 in NHANES I to 0.956 in NHANES II and then to 0.948 in NHANES III and the differences between the Union Army sample and NHANES II and III were statistically significant in a pooled sample. However, controlling for smoking reduces the impact of education on mortality to 0.977 in NHANES 1 and to 0.965 and 0.964 in NHANES II and III. With further smoking controls the impact of education falls to 0.979 in NHANES III. The increase in mortality differentials by education for men dates to at least 1960, whereas educational differentials among women remained relatively constant (see the review by Dow and Rehkopf 2010), consistent with women's later take-up of smoking. ${ }^{17}$

The growing importance of education in maintaining medical regimes also may explain the rising education gradient in older age mortality. Glied and Lleras-Muney (2008) report steepening education gradients in mortality among causes of death for which there was greater technological progress. Smith (2007) finds that the education gradient in diabetes prevalence has increased since the 1970s, perhaps because of better self-management at higher educational levels (Goldman and Smith 2002). ${ }^{18}$ Technological change also will disproportionately benefit the advantaged because they are the heaviest health care users and new medical technologies raise the productivity of health care (Goldman and Lakdawalla 2005).

Evidence from experimental animal studies has led to the recognition of the role of stress in health and mortality, particularly for hypertension and atherosclerosis (e.g. Henry and Stevens 1977), and to its effects on the next generation, through gene imprinting (Tung et al.

\footnotetext{
${ }^{17}$ The results in Table 8 differ from those of Cutler et al. (2011) who find that smoking trends explain little if any of the increase in relative mortality risk for the less educated over the last three decades. A potential explanation for the differences is that in the broad 25 to 74 year old age group examined by Cutler et al. (2011) the number of years spent smoking within educational groups may vary widely.

${ }^{18}$ In contrast, Goldman and Smith (2005) find no educational gradient in hypertension.
} 
2012). The effects of stress may be mediated by social networks. Perceptions of social support are associated with better adjustment to stressful events (e.g., House et al. 1988; Lett et al. 2007) even though actual social support often is not correlated with better adjustment (e.g., Bolger and Amarel 2007). Social networks may positively affect cellular immune response (Cohen et al. 1992; Thomas, Goodwin, and Goodwin 1985) and neuroendocrine functioning (Seeman et al. 1994); feelings of social isolation may even be linked to alterations in the activity of genes that drive inflammation, the first response of the immune system (Cole et al. 2007). One of the difficulties of studying people is that those who are in poor health may be socially isolated, making it hard to establish causality. Among Union Army veterans, for whom both wartime stress and the cohesion of the wartime company were arguably exogenous, wartime stress increased older age mortality rates but men from more cohesive companies were statistically significantly less likely to be affected by wartime stress (Costa and Kahn 2010).

While stress and social support may explain some health inequalities, it is hard to implicate stress and social support in the increase in health inequalities. Putnam (2000) emphasized the decline of social capital, but evidence on trends is mixed (Costa and Kahn 2003). Even less is known about changes in stress levels. Stevenson and Wolfers (2008) find that selfreported happiness by educational level has widened since the 1970s but that the differences by race and by sex have narrowed, the latter because women no longer report higher happiness rates than men and now report lower rates.

\section{Health Inequality within Families}

Families are now more likely to transmit good health to all of their children. Among whites, sibling correlation in birth weights, birth length, and gestational weeks has since the 1920s (see Table 9). ${ }^{19}$ These correlations, which control for birth order, show that among children born under the auspices of Johns Hopkins University Hospital, sibling correlations in birth weight and gestational weeks were lower than among children born in 1955-66 and surveyed in the Collaborative Perinatal Project and those in turn were lower than those observed in the data from Norway from 1967-2004 and in the PSID from 1985-1997. Sibling correlations in birth length were greater in 1967-2004 than in the Johns Hopkins University sample in the first third of the $19^{\text {th }}$ century.

The narrowing of brother correlations in adult height shows that inequality within families has decreased since the Civil War cohort (see Table 10). ${ }^{20}$ The most likely cause for the low correlation in the past is families' inability to protect themselves against disease and nutritional shocks. Among brothers in the Union Army heights were lower in more populous counties and the variability in height was greater, suggesting that the environmental contribution to variability in height is of greater relative importance in populations reared in worse environments (Lauderdale and Rathouz 1999). Not only has the disease environment improved but families may now also be better able to protect themselves against shocks that do occur because of improvements in knowledge.

\footnotetext{
${ }^{19}$ Sample sizes for blacks are too small to determine the trend.

${ }^{20}$ The US decline in brother-brother correlations is consistent with the increase in height heritability observed among Finnish twins born in the first half of the 20th century and those born later (Silventoinen et al. 2000).
} 


\section{Causes of the Mortality Transition: Micro-Evidence}

Trends in health and in health inequality suggested that technological innovations, first in the form of public health interventions and then in the form of medical treatments and personal health regimes, were the primary drivers of changes in health and in health inequality, swamping any effects of income trends. This section reviews some of the microevidence. The micro-evidence consists of correlational evidence, particularly for some of the historical studies, studies of specific public health interventions, studies of exogenous income transfers, and studies of exogenous schooling increases. On the whole, this evidence shows that both the disease environment and arguably exogenous increases in income were important determinants of health and mortality in the nineteenth century and the early twentieth century but that the importance of both these factors fell over the course of the $20^{\text {th }}$ century. The evidence on education is less clear.

The decline in health that began in the 1830s has been analyzed using cross-sectional data by various scholars. Haines et al. (2000)'s analysis of 1850 county-level death rates finds no statistically significant effect of various measures of nutritional availability but does find statistically significant effects of transport access and urbanization. In contrast, their analysis of the heights of Union Army soldiers finds a positive and statistically significant effect of nutritional availability, some evidence that growing food specialization had a negative effect, evidence of the negative effects of transport access and urbanization, and a sizable negative effect of crude deaths rates, an indicator of the infectious disease environment. They cannot determine why crude death rates rose, but the increase in both immigration and in internal migration is a likely explanation. Union Army recruits who spent their early years in counties where malaria was endemic were 1.1 inches shorter at enlistment and $13 \%$ more susceptible to infection (Hong 2007). Westward expansion before the drainage of the wet lands brought the population into the malarial Midwest.

The importance of infectious disease to mortality, particularly infant mortality, is illustrated by cities' adoption of clean water technologies. City life in the $19^{\text {th }}$ and early $20^{\text {th }}$ century was dirty and dangerous (Melosi 2000). The water and milk supply of cities was contaminated with bacteria causing typhoid fever, dysentery, and diarrhea. Cities did not remove sewage and their streets were filled with garbage and carrion. The influx of migrants from abroad and from rural areas crowding into dank and dark urban tenements provided new foci of infection and new victims, and the rapid transmission of disease from host to host increased its virulence. Among infants the excess urban mortality was 88 percent in 1890 and 48 percent in 1900 (Haines 2001) and nowhere was the urban mortality penalty as large as in the poor areas of town where crowding was greater and where parents could not afford to buy clean water and milk (Rochester 1923). City life left those who survived to age 60 permanently scarred, shortening their lives at older ages even controlling for later residential moves (Costa 2003; Costa and Lahey 2005a). The adoption of clean water technologies sharply lowered mortality rates. In Chicago $30-50 \%$ of the $60 \%$ decline in crude death rates between 1850 and 1925 is accounted for by water purification and the eradication of diarrheal diseases and typhoid fever and its sequelae (Ferrie and Troesken 2008). In major cities between 1900 and 1936 overall mortality rates fell by $30 \%$ and infant 
mortality rates by $62 \%$. Clean water (both filtration and chlorination) accounted for 43 and $74 \%$ of the reductions, respectively (Cutler and Miller 2005).

Many other interventions, such as cleaning the milk supply and city vaccination campaigns, remain understudied. We do not know the effects of slum clearing, though we do know that shared toilet facilities were correlated with high infant mortality both in the United States and in Germany (Brown 2000a). We cannot assess the impact of cleaner air. Although early air monitoring data do not exist, problems were severe enough that monitoring was moot. Pittsburgh streetlights burned all day because the skies were darkened by pollution and white shirt collars would turn gray by mid-day. The city replaced coal with natural gas as its major fuel between 1884-1892, but then it depleted its gas supplies and its skies were darkened once more. Only in 1941 did the city reduce its use of bituminous coal and it continued to reduce its reliance on coal after WWII (Tarr 2002; Tarr and Lamperes 1981). Jack London (1903) cited scientific studies that "no less than six tons of solid matter, consisting of soot and tarry hydrocarbons, are deposited every week on every quarter of a square mile in and about London." He added that "sulphuric acid in the atmosphere is constantly being breathed by the London workmen through all the days and nights of their lives." Clay and Troesken (2011) found that "foggy" days in London correlated with excess mortality and that the number of these days rose from 1870 to 1891 and then fell until their series ended in 1905 . They attributed the decline to population shifts from the center city, fines for excess smoke emissions instituted in 1891 which led to switches from bituminous coal and to more efficient stoking and firing procedures, and the spread of gas cookers and heating, particularly among the poor.

Conditions in cities have led historians, particularly those of British economic history, to wonder why migrants moved from the country-side to the dark satanic mills of the cities. Williamson (1981), looking at average death rates and wage rates across cities from the 1800 s to the 1860 s, argued that there was a $10-24 \%$ wage premium for city life in England as whole but that even this mortality premium was not enough to erase the wage gain of moving from the village to the city. Given the variance in mortality rates within cities, the wage premium may be underestimated. However, the wage gain to moving to the city may have been particularly high for those born in the country. Jack London described those born in the East End as, "a weak-kneed, narrow-chested, listless breed, that crumples up and goes down in the brute struggle for life with the invading hordes from the country." He added that, "The railway men, carriers, omnibus drivers, corn and timber porters, and all those who require physical stamina, are largely drawn from the country; while in the Metropolitan Police there are, roughly, 12,000 country-born as against 3000 London-born." In addition, cities provided upward job mobility, leading to the migration of the more able (Long 2005). While we know that the infants of city-dwellers suffered, we do not know how the health of the "invading hordes from the country" declined. As city conditions worsened, an adolescence and an adulthood spent in large cities was at least as dangerous as being born in a large city under somewhat better conditions (Cain and Hong 2009).

Evidence on the declining importance of early life environmental conditions comes from studies of the impact of season of birth. Doblhammer and Vaupel (2001) discovered that in recent populations those 50 years old and over born in the northern hemisphere live longer if 
they were born in the fourth quarter instead of the second quarter whereas in the southern hemisphere the pattern is exactly reversed. They argue that those born in the second quarter, after the long winter months, experienced reduced intrauterine growth. The populations they examined were for the most part born in the twentieth century when the mortality transition was already well under way.

Costa and Lahey (2005a,b), comparing the Union Army cohort with US cohorts born 18811920 , learned that the effect of being born in the second quarter of birth relative to the fourth on older age mortality has lessened and that whereas there was a pronounced negative effect of being born in the summer among the Union Army cohort, this effect disappeared almost entirely for the 1881-1920 cohort. Spring and summer were bad seasons to be born in both because of the inadequacy of maternal diets and high infectious disease incidence in early infancy and early pregnancy. At Johns Hopkins in the first third of the twentieth century babies born during the second quarter (April-June) were more likely to be premature and babies born during the spring (March-May) had lower birth weights, even if they were fullterm (Costa 2004b). The mortality of infants and of children below age two peaked in the summer because of diarrhea and its sequelae throughout the nineteenth century, starting to dampen in the late nineteenth and early twentieth century but persisting until 1920 (Condran and Lentzner 2003). A study of a rural North Carolina mill town begun in 1939 found that in the spring vitamin levels were at their lowest point (Beardsley 1989: 204). Poor nutritional intake and maternal infection from respiratory disease during the winter months may have led to low birth weights and high prematurity rates among babies born in the spring. The impact of season of birth effects fell between 1900 and 1960-80, coincident with declining infectious diseases rates, particularly from summer water-borne diseases, and a more varied diet. The declining impact of season of birth accounts for roughly 16 to 17 percent of the 0.087 difference in the 10 year mortality rates of Union Army veterans and of Americans in 1960-1980.

Analyses of the mortality impact of temperatures provide additional evidence on the declining importance of environmental conditions. Using state-level mortality data, Barreca et al. (2013) find that the mortality effect of an extremely hot day declined by about $80 \%$ between 1900-1959 and 1960-2004. The effect of cold days on mortality decreased as well but the effects were more modest than for hot temperatures, probably because of the importance of waterborne diseases such as typhoid and diarrhea circa 1900. Deschênes and Moretti (2009), using individual-level data, find that cold temperature days have a significant and long-lasting impact on mortality rates (much more than hot days) in 19721988 and attribute $3 \%$ to $7 \%$ of the gains in longevity experienced by the U.S. population over the past three decades to migration from cold, northeastern states to warm, western states.

The shift from manual to white collar work accounts for a large fraction of the improvement in health at older ages but not of mortality. Among Union Army veterans, occupational shifts were relatively unimportant predictors of older age mortality (Costa 2013) but explain $29 \%$ of the $66 \%$ decline in the combined category of chronic respiratory conditions, valvular heart disease, arteriosclerosis, and joint and back problems from the 1900s to the 1970s and 1980s. The fraction of the decline explained by occupational shifts was larger than the $18 \%$ 
explained by the disease environment as proxied by early life urban residence and infectious illnesses in the army (Costa 2000). Occupational hazards within manual and factory occupations have fallen. In addition to injuries and physical demands, lung diseases and respiratory symptoms result from occupational exposure to dust, fumes, or gases in manufacturing, mining, and farming. In the United States men's risk of death on wagepaying jobs fell from roughly 0.17 per million hours worked circa 1940 to less than 0.07 by 1970, with most of the decline due to decreased risk of death within jobs (Costa and Kahn 2004). Nonetheless, even controlling for education and income, those in manual occupations today have worse self-reported health and more rapidly declining health with age (Case and Deaton 2003).

Income in the $19^{\text {th }}$ century enabled individuals to buy lower room congestion, housing in an area of a city with better sanitation, private toilet facilities, soap, better food, an icebox to preserve food, and less work away from home for the pregnant mother. Thus Preston and Haines (1991), using the questions on the number of children ever born and the number of children living in the 1900 census, report that place of residence, together with race, was the important correlate of child survival in the late $19^{\text {th }}$ century, much more important than father's occupation. However, within locations, income mattered. Within U.S. cities there was a steep gradient between infant mortality and income. In Providence, Rhode Island, in 1865 the annual crude death rate for taxpayers was 11 per thousand, while the corresponding rate for non-taxpayers was 25 per thousand (Chapin 1924). Reduced occupational stress includes both the shift from manual to white collar work and the reduction in occupational hazards within manual and factory work.. Ferrie (2003) linked households in 1850 and 1860 to one year mortality rates as reported in the 1850 and 1860 censuses of mortality and found a wealth gradient in rural areas of the United States. Those with greater personal wealth were less likely to die from any cause and from pulmonary tuberculosis, a disease associated with crowding and poor housing. They were no less likely to die of cholera, a disease they did not know was spread through contaminated water supplies. Among Union Army veterans, an extra $\$ 1$ in exogenous income lowered mortality hazards by $21 \%$ (Eli 2012). Effects were large for respiratory, digestive, and cardiovascular illnesses, all conditions predicted by previous bouts of infectious disease (Costa 2000). Pensions decreased veterans' exposure to infectious disease and to occupational hazards by allowing them to retire, to live independently of their children, and to live in better areas.

Income transfers in the 1930s and at mid-century also had substantial effects on mortality. Relief spending during the Great Depression reduced infant mortality and deaths from diarrhea and infectious disease, with a dollar increase in relief spending reducing overall infant mortality by more than 30\% (Fishback, Haines, and Kantor 2007). Old Age Assistance decreased elderly mortality by $22 \%$ between 1930 and 1950, but only among men. Their infectious disease mortality fell with the shift away from the crowded housing of the poorhouse and access to antibiotics, particularly penicillin, and sulfa drugs (Balan-Cohen 2008). The (male) children of poor mothers who received pensions because of husband's death, disability, or absence between 1900 and 1930 lived ten years longer than the children whose mothers' applications were rejected (Aizer et al. 2013). 
Income transfers in more recent times may have a negative impact on older age mortality in developed countries. Using exogenous decreases in income arising from adjustments to erroneous overpayments of Social Security benefits, Snyder and Evans (2004) uncovered a small but statistically significant positive impact of income on male mortality, with a $4 \%$ decline in Social Security payments lowering male mortality by $2 \%$ (there was no effect on women's mortality). They argue that the decline in mortality can be explained by the increase in part-time employment among men older than 67, perhaps because of the beneficial effects of increased social interactions. In contrast, in South Africa, the extension of generous pensions to elderly blacks led to improved self-reported health status and decreased depression for all household members because richer households were able to obtain on-site water and flush toilets and were less likely to skip meals (Case 2001).

The impact of income on birth outcomes in more recent times is smaller than in the 1930s, as might be expected given higher income levels and better health. The income maintenance experiments of the 1970s in Gary, Indiana, which guaranteed families a certain income level had positive effects on the birth weights of children of mothers who were smokers and who had short intervals between births but negative effects on the children of mothers who were non-smokers and who had long intervals between births compared to controls who did not (Kehrer and Wolin 1979). The differential county roll-out of the Food Stamp Program, which is equivalent to a cash transfer (Hoynes, Schatzenbach, and Whitmore 2009), also provides evidence on exogenous income effects. Exposure to the program in the last trimester had small and statistically insignificant effects on neo-natal mortality and a less than half a percent increase for blacks and whites in mean birth weight. However, it had a $7 \%$ reduction in the incidence of low birth weight for whites and 5 to $11 \%$ reduction for blacks (Almond, Hoynes, and Schanzenbach 2011). Using the differential county roll-out of the Supplemental Program for Women Infants and Children, which provides food packages to low-income pregnant and postpartum women, Hoynes, Page, and Stevens (2011) find that the program increased birth weights by only 19 to $28 \mathrm{~g}$ among participating women, a less than $1 \%$ increase (cf. Bitler and Currie 2005). Declines in the welfare case load because of the Personal Responsibility and Work Opportunity Reconciliation Act (PRWORA) which eliminated entitlement to cash assistance had either no or small effects on birth weight (Currie and Grogger 2002; Kaestner and Lee 2005).

The large effect of income on health in the past is not inconsistent with the deviation of health trends from income. Income was important but disease was even more so. The rather modest effects of exogenous income changes on health in the US today compared to strong correlations between income and health suggest either that the causality is reversed or that income is picking up other factors. One likely other factor is education, which is strongly positively associated with health, but identifying causal effects of education has been a challenge.

Lleras-Muney (2005) pioneered the use of compulsory schooling and child labor laws as instruments to estimate the causal impact of education on health. Her revised estimates (Lleras-Muney 2006) imply that an extra year of schooling lowers mortality risk at older ages by nearly 70 percent, but the results are not robust to using different codings of the laws, to the expansion of the sample, and to the use of state-specific cohort effects 
(Mazumder 2008). Mazumder (2008), using compulsory schooling and child labor laws as an IV, finds robust effects of education on older age chronic conditions such as diabetes, vision, hearing, speaking ability, back problems, deformities, and senility. With the exception of diabetes, none of these conditions are related to the ability of the better educated to make better use of new information or medical technologies, leading Mazumder (2008) to conclude that compulsory schooling and child labor laws are suspect instruments and are probably picking up the many public health initiatives occurring in schools during the time period, such as smallpox vaccinations.

Other research using compulsory education as instruments finds small effects at best. Changes in British compulsory schooling laws that increased the minimum school leaving age from 14 to 15 in 1947 and from 15 to 16 in 1972 (both years unlikely to be affected by public health initiatives) had no health effects and did not affect smoking habits (Clark and Royer 2013). Using differences in school entry policies between California and Texas, McCrary and Royer (2011) find that an extra year of maternal education has little effect on either the birth weights or prematurity effects of infants born in the 1990s and no effects on fertility. However, they find some suggestive evidence that an extra year of education lowers the incidence of low birth weight among blacks. A compulsory education reform in Sweden which affected the 1946-57 birth cohorts had negligible effects on long-term health (Meghir et al. 2013). Why are these estimates so small? Perhaps an extra year of education has an impact only at very low education levels or only the difference between college and less than college matters. If the health effects of education largely operate through smoking, it may be hard to identify an impact of education if the educational gradient in smoking between those with compulsory schooling and those with less is small.

The causality may also run from health to education (Currie 2009) or both education and health may be determined by a third factor such as time or risk preferences (Fuchs 1982). Using data on British cohorts born in 1970, Conti, Heckman, and Urzua (2011) explicitly model selection into education by those with high cognitive and non-cognitive skills and health status at age 10. Examining health differences at age 30 between those with more than compulsory schooling levels and those with compulsory schooling levels, they estimate that the causal effect of education explains most differences in smoking behavior but that education leads to risky behaviors such as cannabis use (or willingness to report usage). Overall, education explains less than half of self-reported health differences among men but more than half among women.

\section{Health and Productivity}

Jack London claimed that he, "would turn out an amount of work in the course of the day that would put to shame the amount he [the British laborer] turned out. So there are two sides to it. The man with the high standard of living will always do more work and better than the man with the low standard of living." Height has been shown to be strongly associated with wages and productivity in a variety of settings. Surveying the evidence from developing countries, Schultz (2002) concludes that an additional centimeter of adult male height is significantly associated with a higher wage of $1.5 \%$ in Ghana and $1.4 \%$ in Brazil. Historical data also shows that height was associated with lower productivity in now- 
developed countries. Data from the antebellum American South shows that height and weight were positively associated with slave value, suggesting that better fed, healthier slaves were more productive (Margo and Steckel 1982). In the contemporary US, taller individuals also earn higher wages (Case and Paxson 2008), although the "height premium" is higher in developing countries than in the US (where one more centimeter raises wages by $0.45 \%$ ). However, this evidence does not purely reflect the better physical health of taller individuals-improved conditions in childhood will often result both in better health and cognitive abilities, even in developed countries (Case and Paxson 2008, Schick and Steckel 2012, Barham et al 2013). ${ }^{21}$ For example, early life health interventions providing extra medical care in both Chile and Norway, two countries at very different stages of development, led to higher academic achievement in school (Bharadwaj, Løken, and Neilson 2013).

One of the implicit assumptions in the literature has been that in the US past, returns to height were as high as they are in developing countries today, thus suggesting that improvements in health account for a large fraction of productivity gains (e.g. Floud et al. 2011: 20-24; Costa and Steckel 1998). Controlling for education, estimates from developing countries report a coefficient of height in centimeters on log wages of 0.008 in Columbia (Ribero and Nuñez 2000, Table 5, Column 6), of 0.023 in Mexico (Vogl 2014, Table 2, Column 4, and Table 4, Column 1), 0.015 for Ghana and of 0.014 for Brazil (Schultz 2002). In contrast, similar specifications for the US yield an estimate of 0.005 (Schultz 2002).

The historical evidence suggests that returns to height in the United States circa the midnineteenth century were very low and that they have risen over time. Bleakley et al. (forthcoming) estimate that, for climbing the occupational ladder, the returns to height controlling for education were at most 0.002 in the mid-nineteenth century, 0.001 circa WWII, and 0.004 by the 1970s and 1980s. Even if the wage returns to height were twice the occupational ranking returns (as was true circa 1980), the returns to height would be smaller than in most developing countries. A similar temporal increase is observed in the wealth returns to height (see the top panel of Figure 17), though the wealth returns to height were mainly for farmers. At the same time the returns to education to climbing the occupational ladder and to wealth have risen (see the bottom panel of Figure 17). Bleakley et al. (forthcoming) estimated specifications for wealth and for occupational ranking both with and without a control for education. Although in the nineteenth century controlling for education did not affect the returns to height of climbing the occupational ladder, controll3ing for education decreased the returns to height in the twentieth century, suggesting that height effects are now operating more through educational effects. The growing returns to height are consistent with Bleakley et al.'s (forthcoming) hypothesis of a movement from a brawn to a brain based economy. In the nineteenth century, height may have brought returns in the jobs requiring physical stamina such as coal, corn, or timber carrying, but it was not sufficient for climbing the occupational ladder.

\footnotetext{
${ }^{21}$ An alternative explanation for the returns to height is that height is correlated with personal traits conducive to worker productivity, such as emotional skills and extraversion. For example, if the tall receive more investments and praise they become more optimistic and also have better communication skills (e.g. Persico et al. 2004; Mobius and Rosenblatt 2006). In addition, the tall may be placed in leadership roles because they are tall.
} 
The returns to BMI are also different between developing countries and the US in the past. In developing countries BMI is positively related to wages, arguably because in these countries a higher BMI is associated with physical strength which is valued in manual labor (Strauss and Thomas 1998). However, for the US Civil War non-farm cohort, unlike developing countries today, BMI and occupational ranking were unrelated (see Table 11). ${ }^{22}$ BMI and occupational ranking were positively related for the World War II non-farm cohort, but each unit increase in BMI only increased occupational ranking by $0.2 \%$. Among more recent cohorts, once I controlled for education, there was no relation between BMI and occupational ranking and it was negative without controls for education. In contrast in the Côte d'Ivoire the OLS coefficient on BMI in a log wage regression is 0.045 and in Ghana it is 0.053 (Schultz 2003).

In the evidence presented thus far on US returns to height and BMI the health measures depend not just on malleable environmental factors but also on genetics and measurement error. One strand of the literature (see the survey in Shultz 2001) has therefore focused on using instrumental variables for health such as the local price of health inputs and access to health care or community level investments in disease prevention and treatment to identify the effects of the component of health due to environmental factors. Schultz (2002) finds that relative to the OLS estimates the IV estimates of male wage returns to height in Ghana were 5 times greater and in Brazil were 3 times greater. Schultz (2003) was also able to estimate male wage returns to BMI for Ghana and Côte d'Ivoire and found that the IV estimates were greater than the OLS estimates. However, when the primary interest is in determining how the relationship between height and productivity has changed and when no instruments are available for US heights over a century and half, reduced form estimates, estimated using similar specifications and sample restrictions, can establish long-run trends.

An alternative strategy for estimating the returns to health, but limited to a single point in time, has been to examine either early life exogenous shocks or the impact of exogenous health interventions. By comparing the lighter and heavier twin, Black, Devereux and Salvanes (2007) show that low birth weight has a causal effect on adult height, earnings, and education. The sons of mothers infected during the influenza pandemic of 1918 suffered an annual wage income loss of about 5-9\% and up to to half of the total wage effect might be due to decreased educational attainment (Almond 2006). ${ }^{23}$ Bleakley's (2007) study of the hookworm eradication program in the U.S. South concluded that hookworm infections through childhood reduced adult wages by about $40 \%$. Controlling directly for education did not significantly change the estimated effect of hookworm treatment, but changes in literacy suggested that effective deworming increased the productivity of time spent in school. His analysis of malaria eradication in the US South, Mexico, Columbia, and Brazil implies that persistent childhood malaria infection reduces adult income by around $50 \%$ with similar estimates for all four countries studied even though income levels and institutions were very different. Results for education were mixed. We do not know whether evidence from disease

\footnotetext{
${ }^{22}$ Returns to BMI were negative among all men because farmers were the heaviest and also had a low occupational ranking.

23 Brown and Thomas' (2013) re-examination of the influenza pandemic suggests that Almond's strategy of using adjacent cohorts as control groups in invalid because the children born during the WWI draft were born to lower income fathers of large families. Controlling for parental characteristics Almond could not observe in his data, they find no effect of the influenza pandemic. They speculate that parents mitigate the adverse effects of early life insults.
} 
shocks would reveal different or similar magnitudes in the nineteenth century before formal education became more important as a channel of upward mobility.

\section{Health and Fertility}

In the short run, declines in child mortality will mechanically increase fertility. In the longer-run, theoretical predictions of the relationship between health and fertility largely hinge on the child quantity-quality tradeoff and thus on the effects of health changes on the prices of child quantity and quality. Whether the price of child quantity or quality declines depends in turn on when in the life cycle individuals are affected by health changes.

Declines in infant mortality lower the quantity price of children, though declines in scarring effects, by improving child cognition, also lower the quality price of children. Improvements in child health and mortality could lower the price of child quality by relaxing constraints on human capital investments. Increases in fertility could result either from declines in infant mortality or from declines in maternal mortality among women whose educational investments are already completed. Declines in fertility could result either from improvements in child health or from declines in maternal mortality for women whose education is not yet completed. In both cases the channel is education. As life expectancy increases the returns to education rise. Even with no changes in life expectancy, improvements in health will lower the cost of child quality if health is complementary with education.

Empirical evidence on the relationship between health and fertility is limited but consistent with theoretical predictions. Hookworm eradication in the US South circa 1910 led to marked decreases in fertility in treatment relative to control areas because this eradication relaxed the constraint of investing in human capital (Bleakley and Lange 2009). When the risk of dying in childbirth in Sri Lanka fell sharply between 1946 and 1953, the propensity to have children during this time period increased (Lleras-Muney and Jayachandra 2009). Albanesi and Olivetti (2010) attribute the baby boom of the 1950s and the subsequent baby bust as in part a response to decreasing maternal mortality which led to an increase in fertility for the cohorts whose education was complete and then a decline for cohorts whose education was not yet complete.

Exogenous declines in fertility could lead to improvements in child health, again through a child quantity-quality trade-off. In twin data from China, an extra child, net of the lower birth weights stemming from twinning, decreases the parent-assessed health of all children (and also their educational outcomes) but the effects are relatively modest (Rosenzweig and Zhang 2009).

\section{Spending on Health}

Clean water technologies and other public health expenditures that made the dramatic mortality declines in cities possible were expensive. The value of the mean big city water system in 1915 was close to $\$ 300$ million in 2003 US dollars (Cutler and Miller 2005). Chicago's water system was valued at \$1027 million in 2003 US dollars (Ferrie and Troesken 2008). These investments in public health infrastructure were a success that disproportionately benefited the poor, including blacks and immigrants. While water 
filtration benefited both blacks and whites, blacks benefited more than whites in terms of disease reduction (Troesken 2004: 135). Within cities the decline in mortality rates in the worse areas, where the poor lived, to the level of the best areas (see Figure 13) also provides suggestive evidence. Cities with more illiterate residents experienced larger mortality reductions from the provision of clean water (Cutler and Miller 2005). City public health expenditures were positively correlated with the fractions of the immigrant and black populations (Costa and Kahn 2006). Public health programs targeted to rural areas, such as the Rockefeller's foundation's anti-hookworm campaign, also disproportionately benefited the poor (Bleakley 2007).

The primary explanation for why US cities spent so much on mortality reductions that disproportionately benefited the poor is that middle class and rich taxpayers viewed public health investments as a type of insurance policy. When the vast majority of a city's employment was located in its downtown and the suburbs were not developed, the rich and poor lived in closer physical proximity, allowing a public health shock in poor neighborhoods to have a contagion effect on rich neighborhoods. When whites and blacks lived in close proximity, failing to install water and sewer mains in black neighborhoods increased the risk of diseases spreading from black neighborhoods to white ones, Blacks gained less from filtration in segregated cities, suggesting that denial of service was more likely when disease spillovers were lower (Troesken 2004: 10, 135). In San Francisco, where typhoid rates were the highest in Chinatown, "[t]he Chinese were in the very center of the city, strategically located to infect the rest of San Francisco with their diseases" (Craddock 2000: 135). Recognizing that this community interacted with the native community through work in laundries or as cooks and domestics outside of Chinatown, civic leaders took pro-active steps to invest in public health.

In contrast to the literature on clean water reforms in the United States, the public health literature on these reforms in Europe has emphasized the political impediments to reform. Szreter (1988) argued that in English cities, the new entrepreneurial class saw no reason to spend on public health (specifically, on clean water) and that political reform, particularly the limited political emancipation of working men, was necessary for sanitation and public health to become a priority. Evans' (1987) case study of the 1892 Hamburg cholera epidemic held the mercantile classes responsible for delays in installing a sand-filtration system, an expenditure in which they could see no benefit to themselves. He argued that they sanctioned their stinginess with laissez-faire ideology and theories of the "miasmatic" origins of disease (which hypothesized that epidemic disease was related to local soil and climatic conditions) and that their desire to avoid trade disruptions led them to conceal the initial outbreak.

The economic history literature presents a more nuanced view on sanitary reforms and implies that a universal franchise was not necessary for implementing these reforms. By the turn of the twentieth century, German cities had become leaders in sanitary reforms. Typhoid mortality rates in Germany were 1.2 times higher than in England and Wales in 1877 but by 1893 were equal and were lower until rates in England and Wales converged to those in Germany. In 1912, 90\% of German households in cities of 50,000 or more were connected to a sewer compared to $75 \%$ of US households in comparably sized cities. But in 
most German cities only the small minority of adult males who paid enough taxes and had legal residence were eligible to vote (Brown 1989, 2000). Noting that in Germany, the United States, and in England, the elite pushed for sanitary reforms, Brown (1989) argued that they were driven in part by self-interest. Healthier workers were better workers; compensating wage differentials were lower in a healthier work environment; and, faced with a slow-down in rural to urban migration and a decline in urban fertility rates, employers feared a labor shortage. Opposition came from small businesses and owners of rental properties because of the funding model. In the US and Germany funding came from a onetime assessment of properties fronting sewers and from annual charges on owners of buildings as well as general tax revenue. In the UK funding in the first half of the nineteenth century came from assessments on home values with the poorest properties exempt. Health expenditures were widely seen as benefiting both the poor and factory owners (see also Brown 2000b; Smith 1979: 216-17; Wohl 1983, Ch. 4 and 7; and Hassan 1985).

Access to capital markets can explain why government, through municipal waterworks, played a large role in the health transition and why large investments in waterworks did not happen earlier. Demand for water was growing. The costs of building sufficiently large water systems were too large for private firms and only the largest cities or cities with access to sophisticated municipal finance techniques could afford them. State constitutions limited borrowing for capital improvements. By facilitating debt finance, the development of a municipal bond market enabled both American and British cities to make the necessary sanitary investments (Brown 1989; Cutler and Miller 2006).

The ability to fund public health investments is not necessarily the only explanation for the timing of the health transition. Cleaning water (sewage largely remained untreated), purifying the milk supply, establishing disease reporting and quarantining systems, disseminating health information to citizens, and ensuring that all babies and children have medical exams and vaccinations required setting up new organizations and co-operation between citizens, doctors, private philanthropists, and city public health departments. Improvements in air quality in Pittsburgh were dependent on knowledge of smoke reduction, on the availability of alternate fuel sources and on infrastructure spending, such as natural gas pipes to homes (Tarr 2002; Tarr and Lamperes 1981). Time to build (including time to finance) meant that the public health expenditures undertaken by US cities at the beginning of the twentieth century were low relative to the value of lives saved under a range of estimates of the value of a life (Costa and Kahn 2006; Cutler and Miller 2005).

By 1940 US cities had solved their sanitation problems and, beginning in the 1970s, the biggest increases in life expectancy began to come at older ages, with technological advances playing a more important role. Seventy percent of the improvement in heart attack survival rates between 1984 and 1998 came from technological improvements in care (Cutler and McClellan 2001). Technological change also played large roles in the survival and quality of life of low birth weight babies, treatments for depression, cataracts, and cancer (Cutler and McClellan 2001). The benefits of medical technology are nicely illustrated by the collapse of Eastern Germany into the arms of Western Germany. Eastern Germany experienced rapid improvements in older age survival rates as technology that was trailing Western standards by 15-20 years was quickly updated (Gjonça, Brockmann, and 
Maier 2000). Another illustration comes from the collapse of segregation in the US South. Once blacks in the rural south obtained legal access to the only nearby hospitals, previously restricted to whites, infant mortality rates fell sharply between 1966 and 1975 because of hospital treatments for pneumonia and gastroenteritis (Almond, Chay, and Greenstone 2006).

In 1913, the United States was spending twice as much on hospitals and health as it was on public poor relief and welfare (Lindert 2004). In contrast, in 1980 the United States was spending three times as much on public poor relief and welfare as hospitals and health for the poor. The well-to-do were not more generous about health spending in the past, they were more self-interested because of fear of infectious disease. As chronic disease replaced infectious disease, health care has become more of a private good and is not necessarily viewed any differently from other types of welfare spending. The issues raised in the social capital literature come to the fore: support for redistribution will be low when the group receiving the transfers differs in race or ethnicity from the group paying for the transfers (e.g. Luttmer 2001;Alesina and Glaeser 2004; Poterba 1997). The public health literature has recognized some of the political economy implications of health care becoming a private good, lamenting that their own profession's emphasis on the importance of individuals' responsibility for their lifestyles and behavior was co-opted by the New Right's agenda to reduce public services (Szreter 2002).

Although the efficacy of medical care is not in doubt, evidence on the efficacy of programs providing free or low cost medical care is mixed. Using age variation in Medicare coverage to identify its effect, several researchers find, at best, very modest health benefits from Medicare, both at the time of its introduction (Finkelstein and McKnight 2008) and in more recent times (Card, Dobkin, and Maestas 2009). Using both geographic variation and variation in the timing of Medicare implementation in Southern counties, Finkelstein and McKnight (2008) find modest effects of Medicare on elderly mortality, with a statistically significant, but still substantively small, decline in nonwhite elderly pneumonia mortality rates. The caveat is that at the time of Medicare's introduction, hospitals were primarily effective at treating short term acute illness, rather than chronic disease.

The expansion of public health insurance to a random group of low-income, uninsured adults in Oregon provides additional evidence. The Oregon health expansion led to a $25 \%$ increase in the probability that people report themselves in good to excellent health and reduced depression rates by $30 \%$ (perhaps because of positive effects, discussed below, on household finances) but had no statistically significant effects on measured blood pressure, cholesterol or glycated hemoglobin (a measure of diabetic blood sugar control) two years after the implementation of the program. The program increased the use of preventive care and thus may have longer term effects (Baiker et al. 2013). However, long-run effects may be limited without adherence to medical therapies and such adherence is absent even with equal access to care within the Veterans Health Administration (Simeonova 2013).

The one exception to this literature finding modest effects of coverage increases is Sommers et al.'s (2014) study of mortality after the Massachusetts Health Care Reform. Annual allcause mortality rates in Massachusetts' 14 counties, stratified by age, sex, and race, fell by 
almost $3 \%$ and mortality rates from amenable causes by almost $5 \%$ relative to control countries in other New England states. The difficulty with the empirical design is uncertainty whether the control counties are a good match and whether there were no other interventions, such as those leading to greater adherence, at the same time.

Evidence both from Medicare and from the Oregon health insurance experiment implies that there is a causal effect of poor health on income. The largest impact of the Medicare program was to reduce elderly out of pocket expenditures. The largest effect of the Oregon health insurance program was to eliminate out-of-pocket catastrophic medical expenditures and reduce by more than $50 \%$ the probability of having to borrow money or skip paying other bills because of medical expenses (Finkelstein et al. 2012).

\section{Valuing Health}

Health expenditures show up in national accounts as a cost but the benefits of health are not counted. The discipline of economics "has fallen seriously behind the economy" (Fogel 1998). To catch up to the economy, researchers have sought both to construct better output measures and better prices for health goods and to quantify the value of improvements in health. Better output measures and prices have been constructed for heart attack treatments (Cutler et al. 1998), glaucoma treatments (Shapiro and Wilcox 1997), and cataracts surgery (Shapiro, Shapiro, and Wilcox 2001) and these reveal that, after accounting for quality, the price of treatments has remained constant or fallen. Measurements of the value of improvements in health are based on value of life calculations (e.g. Nordhaus 2003; Murphy and Topel 2006, 2003). Using a constant value of life, these estimates show that while increases in longevity have been valuable throughout the twentieth century, the early increases in longevity, when the decline in infant mortality led to dramatic increases in life expectancy, are more valuable. Becker, Philipson and Soares (2005) argue that because of declines in infant mortality in developing countries there has been more convergence across nations than the income numbers would suggest.

How soon will we reach diminishing returns to increases in longevity? After 1960, mortality declines have been concentrated at older ages. However, the economic value of these recent mortality declines is arguably larger than the value of the dramatic pre-1960 mortality gains from reductions in infant mortality. Because the value of life rises with increases in wealth and in wages and because we have become wealthier, the smaller, post-1960 increases in life expectancy are more valuable (Costa and Kahn 2004). Will mortality rates at older ages continue to fall? The cohort which will reach age 65 in 2020 was born in 1955 after the steep plunge in infant and child mortality and the literature on scarring and early life factors suggests that this cohort may be particularly long-lived compared to past cohorts. Mortality rates may not fall as steeply for the cohorts born after 1955 as for earlier cohorts. The difference in early life conditions for cohorts born in 1955 instead of 1995 was not as stark as that for cohorts born in 1915 instead of 1955. For cohorts born after 1955 improvements in older age mortality rates will need to come from medical care or better health habits that reduce premature mortality or innovations that decrease the rate of senescence. Without innovation the rate of reduction in future mortality improvements cannot be as sharp as it has been in the recent past. If mortality rates in OECD nations reach a plateau at older ages, 
as the literature indicates is possible (e.g. Vaupel et al. 1998; Carey et al. 1992), then as long as we can change the level of the plateau, investments in health at very old ages will not hit diminishing returns.

Hall and Jones (2007) conclude from their model that health care will consume $30 \%$ of GDP by the middle of the twentieth century and argue that this is a good thing because it reflects consumer preferences for better health over additional consumer goods such as cars. The big issue is how to pay for health care and for medical innovation. Paying for innovation frequently conflicts with a desire for wider health care coverage. Innovation is a public good which benefits both rich and poor, even though the benefits accrue first to the rich, but incentives for innovation depend on the structure of health care. Generous health insurance encourages the diffusion of innovations once they are available, and in turn the development of new innovations (see the review by Cutler 2002). But this innovation is expensive, leading to efforts to reduce health insurance generosity by encouraging managed care or by reducing the tax benefits for generous health insurance policies or to low pharmaceutical prices negotiated by national health care systems. Creating the institutions necessary to maintaining increases in longevity may thus be a challenge.

\section{The Unfinished Agenda}

This review has documented trends in various measures of health, including by socioeconomic status, and findings from micro data on the changing health effects of the environment and of income. The large health effects of exogenous changes in disease and income in the past imply that in the time series income effects have been swamped by disease trends. Modest income effects in recent data suggest that the strong relationship between health and income is now largely driven by reverse causality. The time trends hinted at both longitudinal and intergenerational effects, but we need new data to fill in many missing data points in our historical series on health trends, particularly for women, for chronic conditions, and for birth weights. We need a better understanding of why birth weights were so low for first births but so high for later births. Is birth weight a poor measure of health at birth? If so, what other measures could be used instead? Another empirical challenge will be understanding cognition and mental health in the past. A voluminous literature has established that past populations were underweight and stunted. Recent work on numeracy, grain prices, and poor relief in England before 1850 (Baten et al., forthcoming) suggests they also were cognitively impaired. Elevated schizophrenia levels among those in utero during in famines (Lumey and van Pappel 2013) hints that they were mentally unstable as well.

The literature has established the importance of water filtration and chlorination as perhaps the biggest contributor to the decline in infant mortality during the health transition, but we still have a poor understanding of the efficacy of many of the other public health interventions occurring at the same time such as the establishment of local boards of health, the elimination of malaria through wetland drainage, the cleaning of the milk supply, vaccination and well-baby campaigns, and slum clearing. Our knowledge of recent interventions, including the limitations on their implementation imposed by political economy considerations, is limited as well. If expansions of health insurance are ineffective, 
is it because we need programs to increase adherence to medical regimes? Alternatively, are programs aimed at younger children more cost effective? The Carolina Abcedarian program, which targeted disadvantaged children before age 5, led to decreases in risk factors for cardiovascular and metabolic diseases among children in their thirties who had been randomized into the program (Campbell et al. 2013). However, it is unclear which aspects of the program - the cognitive and social stimulation, the pediatric care, or the free meals, led to the outcomes. Nor is it clear how parents reinforced the program's inputs.

More work is needed to understand health in the context of family choices, not just fertility, but also when and how families mitigate or reinforce health shocks and thus how health is transmitted across generations. Epigenetics is elucidating the biology of this transmission, showing how fathers' and mothers' misfortunes such as famines and sins such as smoking can be transmitted to future generations. The early life experiences and health habits of families thus are dynastically linked through the epigenome, affecting not just the health but also the brain development of future generations and thus potentially influencing behavior, cognition, and personality (Badcock and Crespi 2008). Inheritance is not destiny though: epigenetics shows how the effects of negative shocks can be reversed, and can thus inform choices. However, parents must know how to use this knowledge and must decide how to allocate scarce inputs given the returns to those choices. Health, cognition, and personality all will affect education which in turn may affect choices over own and children's health outcomes. Small initial health differences at birth are magnified into large differences later in life. Models of health therefore need to account for intergenerational links, critical periods of development, and the dynamic interplay between health, personality, cognition, and education. The data requirements for estimating such models are considerable, and new datasets will need to be developed that follow individuals from the womb, or even better their parents' wombs, to the grave. By constructing such datasets for different cohorts we can investigate changes in the transmission of health across generations as economies move from brains to brawn.

This review has noted the importance of understanding how health interacts with other aspects of the economy, particularly with education. The productivity returns to health are now bigger than they were in the US past, suggesting that the importance of health in the economy has grown and that health increases are most effective in increasing economic growth in a brain based economy with the institutions that enable individuals use their health capital to increase their human capital. These institutions are lacking in many developing countries and were adopted at different times in today's developed countries. Historical European micro-data would elucidate the relationship between health and education, health and fertility, and productivity and health. Did good health push early Europeans out of school? In what time periods and under what institutions did improvements in health induce investments in child quality rather than quantity and thus reductions in fertility? Were the occupational returns to health in the past as low in Europe as they were in the US? Does the European experience shed any light on why occupational returns to health were low in the US? Answering these questions will require a big data push. Large-scale micro historical data collections in the US began prior to 1982 (Fogel et al. 1982) and have produced large, longitudinal databases by linking individuals across census records, or even more ambitiously, by also linking across military and pension records. ${ }^{24}$ European historical data 
collections, while extremely valuable in establishing patterns of the demographic transition, have either focused more narrowly on demography or have been smaller-scale.

An underlying theme of this review has been that the US economy would have grown even without improvements in health. However, because the economy is increasingly brain based and health and cognition are linked, even marginal improvements in health now may have large effects on future economic growth.

\section{References}

Acemoglu, Daron; Autor, David. What Does Human Capital Do? A Review of Goldin and Katz's. The Race between Education and Technology. Journal of Economic Literature. 2012; 50(2):426-463.

Acemoglu, Daron; Johnson, Simon. Disease and Development: The Effect of Life Expectancy on Economic Growth. Journal of Political Economy. 2007; 115(6):925-985.

Adair, Linda S. Size at birth and growth trajectories to young adulthood. American Journal of Human Biology. 2006; 19:327-337. [PubMed: 17421008]

Aizer, Anna; Eli, Shari; Ferrie, Joseph; Lleras-Muney, Adriana. The Effects of Means Tested Cash Transfers on Mortality. Los Angeles: Unpublished MS. University of California; 2013.

Aizer, Anna; Stroud, Laura. Education, Knowledge and the Evolution of Disparities in Health. NBER Working Paper Series No. 15840. 2010

Albanesi, Stefania; Olivetti, Claudia. Maternal Health and the Baby Boom. NBER Working Paper No. 16146. 2010

Alesina, Alberto; Glaeser, Edward L. Why the U.S Doesn't Have a European-Style Welfare State?. Oxford University Press; 2004.

Alley, Dawn E.; Chang, Virginia W. The Changing Relationship of Obesity and Disability, 19882004. Journal of the American Medical Association. 2007; 298(17)

Almond, Douglas. Is the 1918 influenza pandemic over? Long-term effects of in utero influenza exposure in the post-1940 US population. Journal of Political Economy. 2006; 114(4):672-712.

Almond, Douglas; Chay, Kenneth Y.; Greenstone, Michael. Civil Rights, the War on Poverty, and Black-White Convergence in Infant Mortality in the Rural South and Mississippi. MIT Department of Economics Working Paper No. 07-04. 2006

Almond, Douglas; Hoynes, Hilary W.; Schanzenbach, Diane Whitmore. Inside the War on Poverty: The Impact of Food Stamps on Birth Outcomes. The Review of Economics and Statistics. 2011; 93(2):387-403.

Almond D, Mazumder B. The 1918 influenza pandemic and subsequent health outcomes: An analysis of SIPP data. American Economic Review: Papers and Proceedings. 2005; 95:258-262.

Ashraf, Quamrul; Lester, Ashley; Weil, David N. NBER Macroeconomics Annual 2008. Vol. 23. Chicago: University of Chicago Press; 2009. When Does Improving Health Raise GDP?.

Katherine, Baicker; Taubman, Sarah; Allen, Heidi; Bernstein, Mira; Gruber, Jonathan; Newhouse, Joseph P.; Schneider, Eric; Wright, Bill; Zaslavsky, Alan; Finkelstein, Amy. the Oregon Health Study Group. The Oregon Experiment - Medicaid's Effects on Clinical Outcomes. New England Journal of Medicine. 2013; 368

Badcock, Christopher; Crespi, Bernard. Battle of the sexes may set the brain. Nature. 2008 Aug 28.454:1054-1055. [PubMed: 18756240]

Bakwin, Harry; Bakwin, Ruth Morris. Body Build in Infants. II. The Proportions of the External Dimensions of the Healthy Infant During the First Year of Life. Journal of Clinical Investigation. 1931:377-394. [PubMed: 16693986]

Balan-Cohen, Andreea. The Effect of Income on Elderly Mortality: Evidence from the Old Age Assistance Program in the United States. Unpublished MS. Tufts University Department of Economics; 2008.

\footnotetext{
${ }^{24}$ See the data available at www.uadata.org.
} 
Barham, Tania; Macours, Karen; Maluccio, John A. Boys' Cognitive Skill Formation and Physical Growth: Long-Term Experimental Evidence on Critical Ages for Early Childhood Interventions. American Economic Review. 2013; 103(3):467-471.

Barker, DJP. Fetal and Infant Origins of Adult Disease. London: British Medical Publishing Group; 1992.

Barker, DJP. Mothers, Babies, and Disease in Later Life. London: British Medical Publishing Group; 1994.

Barker DJP. Adult consequences of fetal growth restriction. Clinical Obstetrics and Gynecology. 2006; 49(2):270-283. [PubMed: 16721106]

Barker, David JP. Human Growth and Cardiovascular Disease. In: Barker, DJP.; Bergman, RL.; Ogra, PL., editors. The Window of Opportunity: Pre-Pregnancy to 24 Months of Age; 61st Nestlé Nutrition Workshop, Pediatric Program; April 2007; Bali. 2008.

Barker, David JP.; Osmond, Clive; Forsen, Tom J.; Kajantie, Eero; Eriksson, Johan G. Maternal and Social Origins of Hypertension. Hypertension. 2007; 50:565-571. [PubMed: 17620523]

Barreca, Alan; Clay, Karen; Deschênes, Olivier; Greenstone, Michael; Shapiro, Joseph S. Adapting to Climate Change: The Remarkable Decline in the U.S. Temperature-Mortality Relationship over the $20^{\text {th }}$ Century. NBER Working paper No. 18692. 2013

Baten, Jörg; Crayen, Dorothee; Voth, Joachim. Numeracy and the Impact of High Food Prices in Industrializing Britain, 1780-1850. Review of Economics and Statistics. Forthcoming.

Beardsley, EH. A History of Neglect: Health Care for Blacks and Mill Workers in the Twentieth Century South. Knoxville, TN: University of Tennessee Press; 1987.

Becker, Gary S.; Philipson, Tomas J.; Soares, Rodrigo R. The Quantity and Quality of Life and the Evolution of World Inequality. American Economic Review. 2005; 95(1):277-291.

Bharadwaj, Prashant; Løken, Katrine Velleson; Neilson, Christopher. Early Life Health Interventions and Academic Achievement. American Economic Review. 2013; 103(5):1862-1891.

Bitler, Marianne P.; Currie, Janet. Does WIC Work? The Effects of WIC on Pregnancy and Birth Outcomes. Journal of Policy Analysis and Management. 2005; 24(1):73-91. [PubMed: 15584177]

Black, Sandra E.; Devereux, Paul J.; Salvanes, KG. From the cradle to the labor market? The effect of birth weight on adult outcomes. Quarterly Journal of Economics. 2007; 122(1):409-439.

Bleakley, C. Hoyt Disease and development: Evidence from hookworm eradication in the American South. Quarterly Journal of Economics. 2007; 122(1):73-117. [PubMed: 24146438]

Bleakley, C. Hoyt Health, Human Capital, and Development. Annual Review of Economics. 2010a; 2:283-310.

Bleakley, C. Hoyt Malaria in the Americas: A Retrospective Analysis of Childhood Exposure. American Economic Journal: Applied. 2010b Apr; 2(2):1-45.

Bleakley, C. Hoyt; Costa, Dora L.; Lleras-Muney, Adriana. Health, Education, and Income in the United States, 1820-2000. In: Boustan, L.; Frydman, C.; Margo, RA., editors. Human Capital and History: The American Record. University of Chicago Press; Forthcoming.

Bleakley, C. Hoyt; Lange, Fabian. Chronic Disease Burden and the Interaction of Education, Fertility, and Growth. Review of Economics and Statistics. 2009; 91(1):52-65. [PubMed: 24163482]

Bloom, David E.; Canning, David; Fink, Günther. Disease and Development Revisited. NBER Working Paper No. 15137. 2009

Bloom, David E.; Canning, David; Sevilla, Jaypee. The Effect of Health on Economic Growth: A Production Function Approach. World Development. 2004; 32(1):1-13.

Bozzoli, Carlos; Angus, Deaton; Climent, Quintana-Domeque. Adult Height and Childhood Disease. Demography. 2009; 46(4):647-669. [PubMed: 20084823]

Bresler DE, Ellison G, Zamenhof S. Learning Deficits in Rats with Malnourished Grandmothers. Developmental Psychobiology. 1975; 8(4):315-323. [PubMed: 1225698]

Brown, John C. Public Reform for Private Gain? The Case of Investments in Sanitary Infrastructure: Germany, 1880-1887. Urban Studies. 1989; 26:2-12.

Brown, John C. Economics and infant mortality decline in German towns, 1889-1912: household behavior and public intervention. In: Sheard, Sally; Powell, Helen, editors. The Body and the City. Vol. 2000. University of Liverpool Press; 2000a. p. 166-193. 
Brown, John C. Wer bezahlte die hygienische Stadt? Finanzielle Aspekte der sanitären Reformen in England, USA, und Deutschland um 1910 [Who Paid for the Sanitary City? Issues and Evidence Ca. 1910]. In: Vögele, Jörg; Woelk, Wolfgang, editors. Stadt, Krankheit, und Tod. Berlin: Duncker and Humblot; 2000b. p. 237-257.

Brown, Ryan; Thomas, Duncan. On the Long Term Effects of the 1918 U.S. Influenza Pandemic. Unpublished MS. Duke University; 2013.

Bygren LO, Kaati G, Edvinsson S. Longevity determined by paternal ancestors' nutrition during their slow growth period. Acta Biotheoretica. 2001; 49:53-59. [PubMed: 11368478]

Cain, Louis; Hong, Sok Chul. Survival in $19^{\text {th }}$ Century Cities: The Larger the City, the Smaller Your Chances. Explorations in Economic History. 2009; 46(4):450-463. [PubMed: 20161075]

Campbell, Frances; Conti, Gabriella; Heckman, James J.; Moon, Seong Hyeok; Pinto, Rodrigo; Pungello, Elizabeth; Pan, Yi. Early Childhood Investments Substantially Boost Adult Health. Science. 2014; 343(6178):1478-1485. [PubMed: 24675955]

Card, David; Dobkin, Carlos; Maestas, Nicole. Quarterly Journal of Economics. 2009; 124(2):597636. [PubMed: 19920880]

Carey JR, Liedo P, Orozco D, Vaupel JW. Slowing of mortality rates at older ages in large medfly cohorts. Science. 1992; 258(5081):457-461. [PubMed: 1411540]

Case, Anne. Does Money Protect Health Status? Evidence from South African Pensions. NBER Working Paper No. 8495. 2001

Case, Anne; Deaton, Angus. Broken Down by Work and Sex: How Our Health Declines. NBER Working Paper No. 9821. 2003

Case, Anne; Lubotsky, Darren; Paxson, Christina. Economic Status and Health in Childhood: The Origins of the Gradient. American Economic Review. 2002; 92(5):1308-1334.

Case, Anne; Paxson, Christina. Stature and status: Height, ability, and labor market outcomes. Journal of Political Economy. 2008; 116:491-532.

Case, Anne; Paxson, Christina. The Long Reach of Childhood Health and Circumstance: Evidence from the Whitehall II Study. The Economic Journal. 2011; 121:F183-F204. [PubMed: 22228912]

Caselli G, Capocaccia R. Age, period, cohort and early mortality: An analysis of adult mortality in Italy. Population Studies. 1989; 43:133-153. [PubMed: 11622024]

Cautero, Kimiko S. Working Time Reconsidered: Evidence on Workers' Health Across the Past Century. Unpublished MS. Harvard University; 1998. Copy available at http://www.econ.ucla.edu/ costa/papers.html

Chang, Virginia W.; Lauderdale, Diane S. Fundamental Cause Theory, Technological Innovation, and Health Disparities: The Case of Cholesterol in the Era of Statins. Journal of Health and Social Behavior. 2009; 50:245-260. [PubMed: 19711804]

Chapin, Charles V. Deaths among taxpayers and non-taxpayers, income tax, Providence, 1865. American Journal of Public Health. 1924; 14:647-651. [PubMed: 18011285]

Chen, Alice; Oster, Emily; Williams, Heidi. Why is Infant Mortality Higher in the US than in Europe?. Unpublished MS. University of Chicago and MIT; 2013.

Clark, Damon; Royer, Heather. The Effect of Education on Adult Mortality and Health: Evidence from Britain. American Economic Review. 2013; 103(6):2087-2120.

Clay, Karen; Troesken, Werner. Did Frederick Brodie Discover the World's First Environmental Kuznets Curve? Coal Smoke and the Rise and Fall of the London Fog. In: Libecap, G.; Steckel, RH., editors. The Economics of Climate Change: Adaptations Past and Present. Chicago: University of Chicago Press; 2011.

Cole, Steven W.; Conti, Gabriella; Arevalo, Jesusa MG.; Ruggiero, Angela M.; Heckman, James J.; Suomi, Stephen J. Transcriptional modulation of the developing immune system by early life social adversity. 2012; 109(50):20578-20583.

Condran, Gretchen A.; Lentzner, Harold R. Early Death: Mortality among Young Children in New York, Chicago, and New Orleans. Journal of Interdisciplinary History. 2004; 34(3):315-354.

Conti, Gabriela; Heckman, James J. Understanding the Early Origins of the Education-Health Gradient: A Framework That Can Also Be Applied to Analyze Gene-Environment Interactions. Perspectives on Psychological Science. 2010; 5(5):585-605. [PubMed: 21738556] 
Conti, Gabriela; Heckman, James J.; Urzua, Sergio. Early Endowments, Education, and Health. Human Capital and Economic Opportunity Working Group, University of Chicago; 2011. Working Paper No. 20111-001.

Costa, Dora L. Height, weight, wartime stress, and older age mortality: Evidence from Union Army records. Explorations in Economic History. 1993; 30:424-449.

Costa, Dora L. Health and Labor Force Participation of Older Men, 1900-1991. Journal of Economic History. 1996; 56(1):62-89.

Costa, Dora L. Unequal at Birth: A Long-term Comparison of Income and Birth Weight. Journal of Economic History. 1998; 58(4):987-1009.

Costa, Dora L. Understanding the Twentieth Century Decline in Chronic Conditions Among Older Men. Demography. 2000; 37(1):53-72. [PubMed: 10748989]

Costa, Dora L. Changing Chronic Disease Rates and Long-term Declines in Functional Limitation among Older Men. Demography. 2002; 39(1):119-138. [PubMed: 11852833]

Costa, Dora L. Understanding Mid-Life and Older Age Mortality Declines: Evidence from Union Army Veterans. Journal of Econometrics. 2003 Jan; 112(1):175-192. 2003.

Costa, Dora L. The Measure of Man and Older Age Mortality: Evidence from the Gould Sample. Journal of Economic History. 2004a; 64(1):1-23.

Costa, Dora L. Race and Pregnancy Outcomes in the Twentieth Century: A Long-Term Comparison. Journal of Economic History. 2004b; 64(4):1056-1086.

Costa, Dora L. Scarring and Mortality Selection among Civil War POWs: A Long-Term Mortality, Morbidity, and Socioeconomic Follow-Up. Demography. 2012; 49(4):1185-1206. [PubMed: 22968939]

Costa, Dora L.; Kahn, Matthew E. Health, Wartime Stress, and Unit Cohesion: Evidence from Union Army Veterans. Demography. 2010; 47(1):45-66. [PubMed: 20355683]

Costa, Dora L.; Kahn, Matthew E. Understanding the American Decline in Social Capital, 1952-1998. Kyklos. Fasc. 1. 2003; 56(1):17-46.

Costa, Dora L.; Kahn, Matthew E. Changes in the Value of Life, 1940-1980. Journal of Risk and Uncertainty. 2004; 29(2):159-180.

Costa, Dora L.; Kahn, Matthew E. Public Health and Mortality: What Can We Learn from the Past?. In: Auerbach, Alan J.; Card, David; Quigley, John M., editors. Poverty, the Distribution of Income, and Public Policy. Russell Sage Foundation; 2006.

Costa, Dora L.; Lahey, Joanna N. Becoming Oldest-Old: Evidence from Historical US Data. Genus. 2005a; 61(1):125-126. 2005.

Costa, Dora L.; Lahey, Joanna N. Predicting Older Age Mortality Trends. Journal of the European Economic Association. 2005b Apr-May;3(2-3) 2005.

Costa, Dora L.; Helmchen, Lorens; Wilson, Sven. Race, Infectious Disease, and Arteriosclerosis. Proceedings of the National Academy of Sciences. 2007; 104:13219-13224.

Costa, Dora L.; Steckel, Richard H. Long-Term Trends in Health, Education, and Economic Growth in the United States. In: Steckel, RH.; Floud, R., editors. Health and Welfare during Industrialization. Chicago: University of Chicago Press for NBER; 1997. p. 47-89.

Craddock, Susan. City of Plagues, Disease, Poverty and Deviance in San Francisco. Minneapolis: University of Minnesota Press; 2000.

Crawford, William; Broadley, Herbert. The People's Food. W. Heineman Ltd.; 1938.

Currie, Janet. Healthy, wealthy, and wise: Socioeconomic status, poor health in childhood, and human capital development. Journal of Economic Literature. 2009; 47(1):87-122.

Currie, Janet; Grogger, Jeffrey. Medicaid Expansions and Welfare Contractions: Offsetting Effects on Prenatal Care and Infant Health? Journal of Health Economics. 2002; 21(2):313-335. [PubMed: 11939244]

Currie, Janet; Hyson, Rosemary. Is the Impact of Health Shocks Cushioned by Socioeconomic Status? The Case of Low Birthweight. American Economic Review. Papers and Proceedings. 1999; 89(2): $245-250$. 
Cutler, David M. Health Care and the Public Sector. In: Auerbach, Alan J.; Feldstein, Martin, editors. Handbook of Public Economics. Vol. 4. Amsterdam: Elselvier Science, North-Holland; 2002. p. 2143-2243.

Cutler, David M.; Deaton, Angus; Lleras-Muney, Adriana. The Determinants of Mortality. Journal of Economic Perspectives. 2006; 20(3):97-120.

Cutler, David M.; Lange, Fabian; Meara, Ellen; Richards-Shubik, Seth; Ruhm, Christopher J. Rising Educational Gradients in Mortality: The Role of Behavioral Risk Factors. Journal of Health Economics. 2011; 30(6):1174-1187. [PubMed: 21925754]

Cutler, David M.; McClellan, Mark. Is Technological Change in Medicine Worth It? Health Affairs. 2001

Cutler, David M.; McClellan, Mark. Productivity Change in Health Care. American Economic Review. 2001; 91(2):281-286.

Cutler, David M.; McClellan, Mark; Newhouse, Joseph P.; Remler, Dahlia. Are Medical Prices Declining? Evidence for Heart Attack Treatments. Quarterly Journal of Economics. 1998; 113(4): 991-1024.

Cutler, David M.; Miller, Grant. The Role of Public Health Improvements in Health Advances: The Twentieth-Century United States. Demography. 2005; 42(1):1-22. [PubMed: 15782893]

Cutler, David M.; Miller, Grant. Corruption and Reform: Lessons from America's Economic History. University of Chicago Press; 2006. Water, Water Everywhere. Municipal Finance and Water Supply in American Cities.

Cutler, David M.; Miller, Grant; Norton, Douglas M. Evidence on Early-Life Income and Late-Life Health from America's Dust Bowl Era. Proceedings of the National Academy of Sciences. 2007; 104(33):13244-13249.

Datar, Ashlesha; Kilburn, M. Rebecca; Loughran, David S. Endowments and Parental Investments in Infancy and Early Childhood. Demography. 2010; 47(1):145-162. [PubMed: 20355688]

Deaton, Angus. Health, Inequality, and Economic Development. Journal of Economic Literature. 2003; 41(1):113-158.

Deaton, Angus. The Great Escape: A Review of Robert Fogel's The Escape from Hunger and Premature Death, 1700-2100. Journal of Economic Literature. 2006; 44(1):106-114.

Deaton, Angus. The Great Escape: Health, Wealth, and the Origins of Inequality. Princeton: Princeton University Press; 2013.

De Beer H. Observations on the History of Dutch Physical Stature from the Late-Middle Ages to the Present. Economics and Human Biology. 2004; 2:45-55. [PubMed: 15463992]

Dehejia, Rajeev; Lleras-Muney, Adriana. Booms, Busts and Babies' Health. Quarterly Journal of Economics. 2004 Aug; 119(3):1091-1130. 2004.

Deschênes, Olivier; Moretti, Enrico. Extreme weather events, mortality, and migration. Review of Economics and Statistics. 2009; 91(4):659-681.

Doblhammer, Gabriele; Vaupel, James W., et al. Lifespan depends on month of birth. Proceedings of the National Academy of Sciences, USA. 2001; 98(5):2934-2939.

Dolinoy, Dana C.; Huang, Dale; Jirtle, Randy L. Maternal nutrient supplementation counteracts bisphenol A-induced DNA hypomethylation in early development. Proceedings of the National Academy of Sciences. 2007; 104(32):13056-13061.

Donahue, Sara MA.; Kleinman, Ken P.; Gillman, Matthew W.; Oken, Emily. Trends in birth weight and gestational length among singleton term births in the United States: 1990-2005. Obstetrics and Gynecology. 2010; 115(2, Pt. 1):357-364. [PubMed: 20093911]

Dow, William H.; Philipson, Tomas J.; Sala-i-Martin, Xavier. Longevity Complementarities under Competing Risks. American Economic Review. 1999; 89(5):1358-1371.

Dow, William H.; Rehkopf, David H. Socioeconomic gradients in health in international and historical context. ANNALS of the New York Academy of Sciences. 2010; 1186:24-36. [PubMed: 20201866]

Drukker, JW.; Tassenaar, Vincent. Paradoxes of Modernization and Material Well-Being in the Netherlands during the Nineteenth Century. In: Steckel, RH.; Floud, R., editors. Health and Welfare during Industrialization. Chicago: University of Chicago Press for NBER; 1997. p. 331-377. 
Easterlin, Richard A. Growth Triumphant: The Twenty-First Century in Historical Perspective. Ann Arbor: University of Michigan Press; 1996.

Easterlin, Richard A. How Beneficient is the Market? A Look at the Modern History of Mortality. European Review of Economic History. 1999; 3(3):257-294. [PubMed: 20509222]

Eastman, Nicholas J. Diabetes Mellitus and Pregnancy: A Review. Obstetrical and Gynecological Survey. 1946; 1(1):3-31. [PubMed: 21022356]

Eli, Shari. Income Effects on Health: Evidence from Union Army Pensions. Unpublished MS. University of Toronto, Department of Economics; 2012.

Elo IT, Preston SH. Effects of early-life conditions on adult mortality: A review. Population Index. 1992; 58:186-212. [PubMed: 12285320]

Evans, Richard J. Death in Hamburg. Society and politics in the cholera years 1830-1910. Oxford: Clarendon Press; 1987.

Ewbank, Douglas C.; Preston, Samuel H. Personal health behavior and the decline of infant and child mortality: The United States, 1900-1930. In: Caldwell, John; Findley, Sally; Caldwell, Patt; Santow, Gigi; Cosford, Wendy; Braid, Jennifer; Broers-Freeman, Daphne, editors. What we know about health transition. Canberra: Australian National University; 1990. p. 116-148.Health Transition Series

Ferrie, Joseph P. The Rich and the Dead: Socioeconomic Status and Mortality in the United States, 1850-1860. In: Costa, Dora, editor. Health and Labor Force Participation over the Life Cycle: Evidence from the Past. Chicago: University of Chicago Press; 2003.

Ferrie, Joseph P.; Troesken, Werner. Water and Chicago's Mortality Transition, 1850-1925. Explorations in Economic History. 2008; 45:1-16.

Finch CE, Crimmins EM. Inflammatory exposure and historical changes in human life-spans. Science. 2004; 305:1736-1739. [PubMed: 15375259]

Finkelstein, Amy; McKnight, Robin. What Did Medicare Do? The Initial Impact of Medicare on Mortality and Out of Pocket Medical Spending. Journal of Public Economics. 2008; 92(7):16441668.

Finkelstein, Amy; Taubman, Sarah; Wright, Bill; Bernstein, Mira; Gruber, Jonathan; Newhouse, Joseph P.; Allen, Heidi; Baicker, Katherine. the Oregon Health Study Group. The Oregon Health Insurance Experiment: Evidence from the First Year. Quarterly Journal of Economics. 2012; 127(3):1057-1106. [PubMed: 23293397]

Fishback, Price V.; Haines, Michael R.; Kantor, Shawn. Births, Deaths, and New Deal Relief during the Great Depression. Review of Economics and Statistics. 2007; 89(1):1-14.

Floud, Roderick. Height, Weight, and Body Mass of the British Population Since 1820. NBER Historical Working Paper No. 108. 1998

Floud, Roderick; Fogel, Robert W.; Harris, Bernhard; Hong, Sok Chul. The Changing Body: Health, Nutrition, and Human Development in the Western World since 1700. Cambridge: Cambridge University Press; 2011.

Floud, Roderick; Wachter, Kenneth; Gregory, Annabel. Height, Health, and History: Nutritional Status in the United Kingdom, 1750-1980. Cambridge: Cambridge University Press; 1990.

Fogel, Robert W. Nutrition and the decline in mortality since 1700: Some preliminary findings. In: Engerman, SL.; Gallman, RE., editors. Long-Term Factors in American Economic Growth. Chicago: University of Chicago Press; 1986. p. 439-556.

Fogel, Robert W. Economic growth, population theory, and physiology: The bearing of long-term processes on the making of economic policy. American Economic Review. 1994; 84(3):369-395.

Fogel, Robert W. Catching Up with the Economy. American Economic Review. 1999; 89(1):1-21.

Fogel, Robert A.; Costa, Dora L. A Theory of Technophysio Evolution, With Some Implications for Forecasting Population, Health Care Costs, and Pension Costs. Demography. 1997; 34(1):49-66. [PubMed: 9074831]

Fogel, Robert A.; Engerman, Stanley L.; Trussell, James. Exploring the uses of data on height: The analysis of long-term trends in nutrition, labor welfare, and labor productivity. Social Science History. 1982; 6:401-421. [PubMed: 11633197] 
Fredericks A, Van Buren S, Burgmeijer R, Meulmeester J, Beuker R, Brugman E, Roede MJ, Verloove-Vanhorick SP, Wilt JM. Continuing positive secular growth change in the Netherlands, 1955-97. Pediatric Research. 2000; 47:316-323. [PubMed: 10709729]

Freedman VA, Crimmins EM, Schoeni RF, Spillman B, Aykan H, Kramarow E, Land K, Lubitz J, Manton K, Martin LG, Shinberg D, Waidmann T. Resolving Inconsistencies in Old-Age Disability Trends: Report From a Technical Working Group. Demography. 2004; 41:417-441. [PubMed: 15461008]

Fuchs, Victor R. Time preference and health: An exploratory study. In: Fuchs, VR., editor. Economic Aspects of Health. Chicago: University of Chicago Press; 1982. p. 93-120.

Gallup, John Luke; Sachs, Jeffrey D. The Economic Burden of Malaria. American Journal of Tropical Medicine and Hygiene. 2001 Jan; 64(suppl. 1):85-96. [PubMed: 11425181]

Garovic, Vesna D.; Bailey, Kent R.; Boerwinkle, Eric; Hunt, Steven C.; Weder, Alan B.; Curb, David; Mosley, Thomas H., Jr; Wiste, Heather J.; Turner, Stephen T. Hypertension in pregnancy as a risk factor for cardiovascular disease later in life. 2010; 284(4):826-833.

Gjonça, Arjan; Hilke, Brockmann; Heiner, Maier. Old-age mortality in Germany prior to and after reunification. Demographic research. 2000; 3(1) http://www.demographic-research.org/volumes/ vol3/1/3-1.pdf.

Glied, Sherry; Lleras-Muney, Adriana. Health Inequality, Education and Medical Innovation. Demography. 2008; 45(3):741-761. [PubMed: 18939670]

Goldin, Claudia; Katz, Lawrence F. The Race between Education and Technology. Cambridge, MA: Harvard University Press; 2008.

Goldin, Claudia; Margo, Robert. The Poor at Birth: Birth Weights and Infant Mortality at Philadelphia's Almshouse Hospital, 1848-1873. Explorations in Economic History. 1989; 26(3): 360-379.

Goldman, Dana P.; Lakdawalla, Darius N. A Theory of Health Disparities and Medical Technology. B.E. Journal of Economic Analysis and Policy: Contributions to Economic Analysis and Policy. 2005; 4(1):1-30.

Goldman, Dana P.; Smith, James P. Can Patient Self-Management Help Explain the SES Health Gradient? Proceedings of the National Academy of Sciences. 2002; 96(16):10929-10934.

Goldman, Dana; Smith, James P. Socioeconomic Differences in the Adoption of New Medical Technologies. American Economic Review. 2005; 95(2):234-237.

Gørgens, Tue; Meng, Xin; Vaithianathan, Rhema. Stunting and selection effects of famine: A case study of the Great Chinese Famine. Journal of Development Economics. 2012; 97(1):99-111.

Gregg EW, Cheng YJ, Cadwell BL, et al. Secular trends in cardiovascular disease risk factors according to body mass index in US adults. JAMA. 2005; 293(15):1868-1874. [PubMed: 15840861]

Grossman, Michael. On the Concept of Health Capital and the Demand for Health. Journal of Political Economy. 1972; 80(2):223-255.

David, Hacker J. Decennial Life Tables for the White Population of the United States, 1790-1900. Historical Methods. 2010; 43(2):45-79. [PubMed: 20563225]

Haines, Michael R. The Urban Mortality Transition in the United States, 1800 to 1940. Annales De Démographie Historique. 2001; 1:33-64.

Haines, Michael R. Inequality and Infant and Child Mortality in the United States in the Twentieth Century. NBER Working Paper No. 16133. 2010

Haines, Michael R.; Craig, Lee A.; Weiss, Thomas. Development, Health, Nutrition, and Mortality: The Case of the Antebellum Puzzle in the United States. NBER Historical Working Paper No. 130. 2000

Hall, Robert E.; Jones, Charles I. The Value of Life and the Rise in Health Spending. Quarterly Journal of Economics. 2007; 122(1):39-72.

Harris, Bernard. Morbidity and mortality during the health transition: a comment on James C Riley 'Why sickness and death rates do not move parallel to one another over time". Social History of Medicine. 1999; 12(1):125-131. [PubMed: 11623803]

Harris, Bernard. Public health, nutrition, and the decline of mortality: The McKeown thesis revisited. Social History of Medicine. 2004; 17(3):379-407. 
Harris, Bernard; Floud, Roderick; Hong, Sok Chul. Food for Thought: Comparing Estimates of Food Availability in England Wales, 1700-1914. Unpublished MS. University of Strathclyde; 2014.

Hassan JA. The Growth and Impact of the British Water Industry in the Nineteenth Century. The Economic History Review. 1985; 38(4):531-547.

Hatton, Timothy J. How have Europeans grown so tall? Oxford Economic Papers. 2013 Advance Access published September 1, 2013.

Hatton, Timothy J.; Bray, Bernice E. Long Run Trends in the Heights of European Men, $19^{\text {th }}-20^{\text {th }}$ Centuries. Economics and Human Biology. 2010; 8(3):405-413. [PubMed: 20399715]

Heckman, James J. The economics, technology, and neuroscience of human capability formation. Proceedings of the National Academy of Sciences, USA. 2007; 104(33):13250-13255. Epub 2007 Aug 8.

Heckman, James J.; Yi, Junjian; Zhang, Junsen. Early Health Shocks, Intrahousehold Resource Allocation, and Child Human Capital. Unpublished MS. University of Chicago, Department of Economics; 2013.

Heijmans BT, Tobi EW, Stein AD, Putter H, Blauw GJ, Susser ES, Slagboom PE, Lumey LH. Persistent epigenetic differences associated with prenatal exposure to famine in humans. Proceedings of the National Academy of Sciences, USA. 2008; 104(44):17046-17049.

Hong, Sok Chul. The burden of early exposure to malaria in the United States, 1850-60: Malnutrition and immune disorders. Journal of Economic History. 2007; 67(4):1001-1035. [PubMed: 19081796]

Horiuchi S. The long-term impact of war on mortality: Old-age mortality of First World War survivors in the Federal Republic of Germany. Population Bulletin of the United Nations. 1983; 15:80-92. [PubMed: 12265835]

Hoynes, Hilary; Page, Marianne; Stevens, Ann Huff. Can Targeted Transfers Improve Birth Outcomes? Evidence from the Introduction of the WIC Program. Journal of Public Economics. 2011; 95:813-827.

Hoynes, Hilary; Schatzenbach, Diane; Whitmore, Diane. Consumption Responses to In-Kind Transfers: Evidence from the Introduction of the Food Stamp Program. American Economic Journal: Applied Economics. 2009; 1(4):109-139.

Jacobs J, Tassenaar Vincent. Height, income and nutrition in the Netherlands in the second half of the nineteenth century. Economics and Human Biology. 2004; 2:181-195. [PubMed: 15464001]

Jayachandran, Seema; Lleras-Muney, Adriana. Life expectancy and human capital investments: Evidence from declines in maternal mortality. Quarterly Journal of Economics. 2009; 124(1): 349-397.

Kaestner, Robert; Lee, Won Chan. The Effect of Welfare Reform on Prenatal Care and Birth Weight. Health Economics. 2005; 14:497-511. [PubMed: 15386659]

Kannisto V, Christensen K, Vaupel JW. No increased mortality in later life for cohorts born during famine. American Journal of Epidemiology. 1997; 145:987-994. [PubMed: 9169907]

Karpinos, Bernard D. Blood Pressure and its Relation to Height, Weight, Race, and Age - World War II. American Journal of Epidemiology. 1958; 68(3):288-311.

Katz, Lawrence F.; Margo, Robert A. Technical Change and the Relative Demand for Skilled Labor: The United States in Historical Perspective. In: Boustan, L.; Frydman, C.; Margo, RA., editors. Human Capital and History: The American Record. University of Chicago Press. Forthcoming.

Kehrer, Barbara H.; Wolin, Charles M. The Impact of Income Maintenance on Low Birth Weight: Evidence from the Gary Experiment. The Journal of Human Resources. 14(4):434-462. [PubMed: 575154]

Komlos, John. The Height and Weight of West Point Cadets: Dietary Change in Antebellum America. Journal of Economic History. 1987; 47(4):897-927.

Komlos, John. Anomalies in Economic History: Toward a Resolution of the "Antebellum Puzzle.". Journal of Economic History. 1996; 56(1):202-214.

Lauderdale DS, Rathouz PJ. Evidence of environmental suppression of familial resemblance: height among US Civil War brothers. Annals of Human Biology. 1999; 26(5):413-426. [PubMed: 10541404] 
Lawrence, Jean M.; Contreras, Richard; Chen, Wansu; Sacks, David A. Trends in the prevalence of preexisting diabetes and gestational diabetes mellitus among a racially/ethnically diverse population of pregnant women, 1999-2005. Diabetes Care. 2008; 31(5):899-904. [PubMed: 18223030]

Leighton G, Clark ML. Milk consumption and the growth of schoolchildren. Lancet. 1929; 1:40-43.

Li, Haojie; Stein, Aryeh D.; Barnhart, Huiman X.; Ramakrishnan, Usha; Martorell, Reynaldo. Associations between prenatal and postnatal growth and adult body size and composition. American Journal of Clinical Nutrition. 2003; 77:1498-1505. [PubMed: 12791630]

Lindert, Peter H. Growing Public: Social Spending and Economic Growth Since the Eighteenth Century. Cambridge University Press; 2004.

Ling, Charlotte; Rönn, Tina. Epigenetic adaptation to regular exercise in humans. Drug Discovery Today. 2014 http://dx.doi.org/10.1016/j.drudis.2014.03.006.

Lleras-Muney, Adriana. The Relationship between Education and Adult Mortality in the United States. Review of Economic Studies,. 2005; 72(1):189-221.

Lleras-Muney, Adriana. The Relationship between Education and Adult Mortality in the United States: Erratum. Review of Economic Studies. 2006; 73(3):847.

London, Jack. The People of the Abyss. New York: The MacMillan Company; 1903. https:// openlibrary.org/books/OL24186399M/The_people_of_the_abyss

Lumey LH, Stein AD. Offspring birth weights after maternal intrauterine undernutrition: a comparison within sibships. American Journal of Epidemiology. 1997; 146(10):810-819. [PubMed: 9384201]

Lumey, LH.; van Poppel, FWA. The Dutch Famine of 1944-45 as a Human Laboratory: Changes in the Early Life Environment and Adult Health. In: Lumey, LH.; Vaiserman, Alexander, editors. Early Life Nutrition and Adult Health and Development. Nova Science Publishers; 2013. p. 59-76.Available on-line at https://www.novapublishers.com/catalog/product_info.php? products_id=37892

Lunde, Astrid; Melve, Kari Klungsøyr; Gjessing, Håkon K.; Skjærven, Rolv; Irgen, Lorentz M. Genetic and Environmental Influences on Birth Weight, Birth Length, Head Circumference, and Gestational Age by Use of Population-based Parent-Offspring Data. American Journal of Epidemiology. 2007; 165(7):734-741. [PubMed: 17311798]

Luttmer, Erzo FP. Group Loyalty and the Taste for Redistribution. Journal of Political Economy. 2001; 109:500-528.

Malthus, TR. An Essay on the Principle of Population. 7th Edition. London: Reeves and Turner; 1872. https://archive.org/stream/anessayonprinci13maltgoog\#page/n6/mode/2up

Manton, Kenneth; Gu, XiLiang; Lamb, Vicki L. Change in chronic disability from 1982 to 2004_2005 as measured by long-term changes in function and health in the U.S. elderly population. Proceedings of the National Academy of Sciences. 2006; 103(48)

Margo, Robert A.; Richard, Steckel. The heights of American slaves: New evidence on slave nutrition and health. Social Science History. 1982; 6(4):516-538. [PubMed: 11633200]

Marmot, Michael; Wilkinson, Richard G. Social Determinants of Health. Oxford: Oxford University Press; 1999.

Martin, Linda G.; Schoeni, Robert F.; Andreski, Patricia M. Trends in Health of Older Adults in the United States: Past, Present, Future. Demography. 2010; 47:S17-S40. [PubMed: 21302428]

Martorell R, Rivera J, Kaplowitz H. Consequences of stunting in early childhood for adult body size in rural Guatemala. Ann. Nestlé. 1990; 48:85-92.

Martyn CN, Barker DJ, Osmond C. Mothers' pelvic size, fetal growth, and death from stroke and coronary heart disease in men in the UK. Lancet. 1996; 348(9037):1264-1268. [PubMed: 8909378]

Mazumder, Bhaskar. Sibling Similarities, Differences and Economic Inequality. Federal Reserve Bank of Chicago WP 2004-13. 2004

Mazumder, Bhashkar. Does Education Improve Health? A Reexamination of the Evidence from Compulsory Schooling Laws. Federal Reserve Bank of Chicago Economic Perspectives. 2008; 32(2):2-16. 
McCrary, Justin; Royer, Heather. The Effect of Female Education on Fertility and Infant Health: Evidence from School Entry Policies Using Exact Date of Birth. American Economic Review. 2011; 101(1):158-195. [PubMed: 21490880]

McKeown, Thomas. The Modern Rise of Population. London: Arnold; 1976.

McKeown, Thomas. The Origins of Human Disease. Wiley-Blackwell; 1981.

McLeod JI, Goldrick RB, Whyte HM. The Effect of Maternal Malnutrition on the Progeny in the Rat. Studies on Growth, Body Composition and Organ Cellularity in First and Second Generation Progeny. The Australian Journal of Experimental Biology and Medical Science. 1972; 50(4): 435-446. [PubMed: 4629706]

Melosi, Martin V. The Sanitary City: Urban Infrastructure in America from Colonial Times to the Present. Baltimore: Johns Hopkins University Press; 2000.

Mehta, Neil K.; Chang, Virginia W. Secular Declines in the Association Between Obesity and Mortality in the United States. Population Development Review. 2011; 37(3):435-451. [PubMed: 22110257]

Meghir, Costas; Pålme, Marten; Simeonova, Emilia. Education, Cognition, and Health: Evidence from a Social Experiment. NBER Working Paper No. 19002. 2013

Mirzaei M, Truswell AS, Taylor R. Coronary heart disease epidemics: not all the same. Heart. 2009; 95:740-746. [PubMed: 19095711]

Mobius, Markus M.; Rosenblatt, Tanya S. Why Beauty Matters. The American Economic Review. 2006; 96(1):222-235.

Mokyr, Joel; Stein, Rebecca. Science, Health, and Household Technology: The Effect of the Pasteur Revolution on Consumer Demand. In: Bresnahan, Timothy F.; Gordon, Robert J., editors. The Economics of New Goods. Chicago: University of Chicago Press; 1996. p. 143-206.

Murphy, Kevin M.; Topel, Robert H. The Economic Value of Medical Research. In: Murphy, Kevin; Topel, Robert, editors. Measuring the Gains from Economic Research: An Economic Approach. Chicago: University of Chicago Press; 2003. p. 41-73.

Murphy, Kevin M.; Topel, Robert H. The Value of Health and Longevity. Journal of Political Economy. 2006; 114(5):871-904.

Nicholas, Stephen; Steckel, Richard H. Tall but Poor: Living Standards of Men and Women in PreFamine Ireland. Journal of European Economic History. 1997; 26(1):105-134.

Nordhaus, William D. The Health of Nations: The Contribution of Improved Health to Living Standards. In: Murphy, Kevin; Topel, Robert, editors. Measuring the Gains from Economic Research: An Economic Approach. Chicago: University of Chicago Press; 2003. p. 9-40.

Olshansky, Jay. A potential decline in life expectancy in the United States in the $21^{\text {st }}$ century. New England Journal of Medicine. 2005; 352(11):1138-1145. [PubMed: 15784668]

Orr, John Boyd. Milk Consumption and the Growth of Schoolchildren. Lancet. 1928; 1:202-203.

Orr, John Boyd. Food, Health and Income: Report on a Survey of Adequacy of Diet in Relation to Income. MacMillan; 1937.

Painter, Rebecca C.; Roseboom, Tessa J.; Bleker, Otto P. Prenatal exposure to the Dutch famine and disease in later life: An overview. Reproductive Toxicology. 2005; 20:345-352. [PubMed: 15893910]

Pembrey M. Male-line transgenerational responses in humans. Human Fertility. 2010; 13(4):268-271. [PubMed: 21117937]

Persico, Nicola; Postlewaite, Andrew; Silverman, Dan. The Effect of Adolescent Experience on Labor Market Outcomes: The Case of Height. Journal of Political Economy. 2004; 112:1019-1053.

Pitt, Mark M.; Rosenzweig, Mark R.; Hassan, Nazmul. Human Capital Investment and the Gender Division of Labor in a Brawn-Based Economy. American Economic Review. 2012; 102(7): 3531-3560. [PubMed: 25152536]

Pope, Clayne L. Adult mortality in America before 1900: A view from family histories. In. In: Goldin, C.; Rockoff, H., editors. Strategic Factors in Nineteenth-Century American Economic History. Chicago: University of Chicago Press; 1992. p. 267-296.

Poterba, James. Demographic Structure and the Political Economy of Public Education. Journal of Policy Analysis and Management. 1997; 16:48-66. 
Preston, Samuel. The changing relation between mortality and level of economic development. Population Studies. 1975; 29(2):231-248. [PubMed: 11630494]

Preston, Samuel H.; Glei, Dana A.; Wilmoth, John R. International Differences in Mortality at Older Ages: Dimensions and Sources. The National Academies Press; 2011. Contribution of Smoking to International Differences in Life Expectancy.

Preston, Samuel H.; Haines, Michael R. Fatal Years: Child Mortality in Late Nineteenth Century America. 1991

Proos LA, Hofvander Y, Tuvemo T. Menarcheal age and growth pattern of Indian girls adopted in Sweden. Catch-up growth and final height. Indian Journal of Pediatrics. 1991; (58):105-114. [PubMed: 1937614]

Putnam, Robert D. Bowling Alone: The Collapse and Revival of American Community. New York: Simon \& Schuster; 2000.

Ray, Debraj. Development Economics. Princeton: Princeton University Press; 1998.

Rehan VK, Liu J, Naeem E, Tian J, Sakurai R, Kwong K, Akbari O, Torday JS. Perinatal nicotine exposure induces asthma in second generation offspring. BMC Medicine. 2012; 10:129. [PubMed: 23106849]

Resnick O, Morgane PJ. Generational Effects of Protein Malnutrition in the Rat. Brain Research. 1984; 317(2):219-227. [PubMed: 6206924]

Ribero, Rocío; Nuñez, Jairo. Adult Morbidity, Height, and Earnings in Colombia. In: Savedoff, WD.; Schultz, TP., editors. Wealth from Health: Linking Social Investments to Earnings in Latin America. Washington, D.C.: Inter-American Development Bank; 2000.

Riggs, Theodore F. A Comparative Study of White and Negro Pelves, with a Consideration of the Size of the Child and Its Relation to Presentation and Character of Labor in the Two Races. Johns Hopkins Hospital Reports. 1904; 12:421-454.

Riley, James C. The Risk of Being Sick: Morbidity Trends in Four Countries. Population and Development Review. 1990; 16:403-432.

Rochester, Anna. U.S Department of Labor, Children's Bureau. Bureau Publication 119. Washington D.C.: Government Printing Office; 1923. Infant Mortality: Results of a Field Study in Baltimore, Maryland, Based on Births in One Year.

Rosenberg M. Birth Weights in Three Norwegian Cities, 1860-1984: Secular Trends and Influencing Factors. Annals of Human Biology. 1988; 15(4):275-288. [PubMed: 3044272]

Rosenthal, Jean-Laurent; Kesztenbaum, Lionel. The democratization of longevity: How the poor became old in Paris, 1870-1940. Unpublished MS. Caltech Division of the Humanities and Social Sciences; 2012.

Rosenzweig, Mark R.; Zhang, Junsen. Do Population Control Policies Induce More Human Capital Investments and China's “One-Child” Policy. The Review of Economic Studies. 2009; 76(3): 1149-1174.

Rowntree, BS.; Lavers, GR. Poverty and the Welfare State. London: Longmans Green; 1951.

Ruhm, Christopher J. Are Recessions Good for Your Health? Quarterly Journal of Economics. 2000; 115(2):617-650.

Sandberg, Lars G.; Steckel, Richard H. Heights and economic history: the Swedish case. Annals of Human Biology. 1987; 14(2):101-110. [PubMed: 3300516]

Sandberg, Lars G.; Steckel, Richard H. Was Industrialization Hazardous to Your Health? Not in Sweden!. In: Steckel, RH.; Floud, R., editors. Health and Welfare during Industrialization. Chicago: University of Chicago Press for NBER; 1997. p. 127-158.

Schick, Andreas; Steckel, Richard H. Height as a Proxy for Cognitive and Non-Cognitive Ability. NBER Working Paper Series. w16570. 2010

Paul, Schultz T. Wage gains associated with height a form of health human capital. American Economic Review. 2002; 92(2):349-353.

Paul, Schultz T. Wage rentals for reproducible capital: Evidence from Ghana and the Ivory Coast. Economics and Human Biology. 2003; 1(2):207-221. [PubMed: 15463974]

Shapiro, Matthew; Wilcox, David. Mismeasurement in Consumer Price Index: An Evaluation. Macroeconomics Annual. 1997; 11:93-142. 
Shapiro, Irving; Shapiro, Matthew D.; Wilcox, David W. NBER Studies in Income and Wealth. Chicago: University of Chicago Press; 2001. Measuring the Value of Cataract Surgery; p. 62

Silventoinen K, Kaprio J, Lahelma E, Koskenvuo M. Relative effect of genetic and environmental factors on body height: differences across birth cohorts among Finnish men and women. American Journal of Public Health. 2000; 90(4):627-630. [PubMed: 10754982]

Simeoni, Umberto; Barker, David J. Offspring of diabetic pregnancy: Long-term outcomes. Seminars in Fetal and Neonatal Medicine. 2009; 14(2):119-124. Diabetes and Pregnancy. [PubMed: 19208505]

Simeonova, Emilia. Doctors, Patients and the Racial Mortality Gap. Journal of Health Economics. 2013; 32(5):895-908. [PubMed: 23933996]

Smith, Francis Barrymore. The People's Health, 1830-1910. New York: Holmes and Meier; 1979.

Smith, James P. Healthy Bodies and Thick Wallets: The Dual Relation Between Health and Economic Status. Journal of Economic Perspectives. 1999; 13(2):145-167.

Smith, James P. The Impact of Socioeconomic Status on Health over the Life-Course. Journal of Human Resources. 2007; 42(4):739-764.

Smith, Stephen. The City That Was. New York: Frank Allaben; 1911.

Snyder, Stephen E.; Evans, William N. The Effect of Income on Mortality: Evidence from the Social Security Notch. The Review of Economics and Statistics. 2006; 88(3):482-495.

Sommers, Benjamin D.; Long, Sharon K.; Baiker, Katherine. Changes in Mortality After Massachusetts Health Care Reform: A Quasi-Experimental Study. Annals of Internal Medicine. 2014; 160(9):586-594.

Steckel, Richard H. Slave Height Profiles from Coastwise Manifests. Explorations in Economic History. 1979; 16:363-380. [PubMed: 11614463]

Steckel, Richard H.; Prince, Joseph M. Tallest in the World: Native Americans of the Great Plains in the Nineteenth Century. American Economic Review. 2001; 91(1):287-294.

Stein, Zena A.; Mervyn, Susser; Saenger, Gerhart; Moraolla, Francis. Famine and Human Development: The Dutch Hunger Winter of 1944-1945. Oxford University Press; 1975.

Stein, Aryeh D.; Zybert, Patricia A.; van de Bor, Margot; Lumey, LH. Intrauterine famine exposure and body proportions at birth: the Dutch Hunger Winter. International Journal of Epidemiology. 2004; 33:831-836. [PubMed: 15166208]

Stein, Aryeh D.; Zybert, Patricia A.; van der Pal-de Bruin, Karin; Lumey, LH. Exposure to famine during gestation, size at birth, and blood pressure at age $59 \mathrm{y}$ : evidence from the dutch famine. European Journal of Epidemiology. 2006; 21:759-765. [PubMed: 17082900]

Stevens, Ann Huff; Miller, Douglas L.; Page, Marianne E.; Filipski, Mateusz. The Best of Times, the Worst of Times: Understanding Pro-cyclical Mortality. NBER Working Paper Series No. 17657. 2011

Stewart TD. Food and Physique. The ANNALS of the American Academy of Political and Social Science. 1943; 225:22-28. 1943.

Stewart, Susan T.; Cutler, David M.; Rosen, Allison B. Forecasting the effects of obesity and smoking on U.S. life expectancy. New England Journal of Medicine. 2009; 361(23):2252-2260. [PubMed: 19955525]

Stevenson, Betsey; Wolfers, Justin. Happiness Inequality in the United States. Journal of Legal Studies. 2008; 37(S2):S33-S79. 06.

Strauss, John; Thomas, Duncan. Health, Nutrition, and Economic Development. Journal of Economic Literature. 1998; 36(2):766-817.

Syddall HE, Sayer AA, Simmond SJ, Osmond C, Cox V, Dennison EM, Barker DJ, Cooper C. Birth weight, infant weight gain, and cause-specific mortality: the Hertfordshire Cohort Study. American Journal of Epidemiology. 2005; 161(11):1074-1080. [PubMed: 15901628]

Szreter, Simon. The importance of social intervention in Britain's mortality decline c. 1850-1914: A reinterpretation of the role of public health. Social History of Medicine. 1988; 1(1):1-36.

Szreter, Simon. Rethinking McKeown: the relationship between public health and social change. American Journal of Public Health. 2002; 92(5):722-725. [PubMed: 11988434] 
Tarr JA. The metabolism of the industrial city— the case of Pittsburgh. Journal of Urban History. 2002; 28(5):511-545.

Tarr JA, Lamperes BC. Changing fuel use behavior and energy transitions-the Pittsburgh Smoke Control Movement, 1940-1950 - a case-study in historical analogy. Journal of Social History. 1981; 14(4):561-588. [PubMed: 11632387]

Troesken, Werner. Typhoid Rates and the Public Acquisition of Private Waterworks, 1880-1920. Journal of Economic History. 1999; 59(4):927-948.

Troesken, Werner. Water, Race and Disease. Cambridge, MA: MIT Press; 2004.

Tung J, Barreiro LB, Johnson ZP, Hansen KD, Michopoulos V, Toufexis D, Michelini K, Wilson ME, Gilead Y. Social environment is associated with gene regulatory variation in the rhesus macaque immune system. Proceedings of the National Academy of Sciences. 2012; 109(17):6490-6495.

Vaupel JW, Carey JR, Christensen K, Johnson TE, Yashin AI, Holm NV, Iachine IA, Kannisto V, Khazaeli AA, Liedo P, Longo VD, Zeng Y, Manton KG, Curtsinger JW. Biodemographic trajectories of longevity. Science. 1998; 280(5365):855-860. [PubMed: 9599158]

Victora, Cesar G.; Adair, Linda; Fall, Caroline; Hallal, Pedro C.; Martorell, Reynaldo; Richter, Linda; Singh Sachdev, Harshpal. Maternal and child undernutrition: consequences for adult health and human capital. Lancet. 2008; 371:340-357. [PubMed: 18206223]

Vogl, Tom. Height, Skills, and Labor Market Outcomes in Mexico. Journal of Development Economics. 2014; 107:84-96.

Waaler, Hans T. Height, weight, and mortality: The Norwegian experience. Acta Medica Scandinavia Supplement. 1984; 679:1-51.

Peter, Ward W. Birth Weight and Economic Growth: Women's Living Standards in the Industrializing West. Chicago: University of Chicago Press; 1993.

Waterland, Robert A.; Jirtle, Randy L. Transposable Elements: Targets for Early Nutritional Effects on Epigenetic Gene Regulation. Molecular and Cellular Biology. 2003; 23(15):5293-5300. [PubMed: 12861015]

Weir, David R. Economic Welfare and Physical Well-Being in France, 1750-1990. In: Steckel, RH.; Floud, R., editors. Health and Welfare during Industrialization. Chicago: University of Chicago Press for NBER; 1997. p. 161-200.

WHO (World Health Organization). WHO Press; 2001. Macroeconomics and Health: Investing in Health for Economic Development. Report of the Commission on Macroeconomics and Health.

Widdowson EM, McCance RA. Some effects of accelerating growth. I. General somatic development. Proceedings of the Royal Society, Ser. B. 1960; 152:188-206.

Williams, John T. Some Observations Upon the Glycosuria of Pregnancy. The Boston Medical and Surgical Journal. 1925; 192(4):163-165.

Williamson, Jeffrey G. Urban Disamenities, Dark Satanic Mills, and the British Standard of Living Debate. Journal of Economic History. 1981 Mar; 41(1):75-83. 1981.

Williamson, Samuel H. What Was the U.S. GDP Then? Measuring Worth. 2014 http:// www.measuringworth.org/usgdp/.

Wohl, Anthony S. Endangered Lives: Public Health in Victorian Britain. Cambridge, MA: Harvard University Press; 1983.

Woods, Robert. The Demography of Victorian England and Wales. Cambridge: Cambridge University Press; 2000.

Yamauchi F. Early Childhood Nutrition, Schooling and Sibling Inequality in a Dynamic Context: Evidence from South Africa. Economic Development and Cultural Change. 2008; 56:657-658. 
Panel A: Life Expectancy at Age 10, Adult Height and Public Health and Medical Milestones

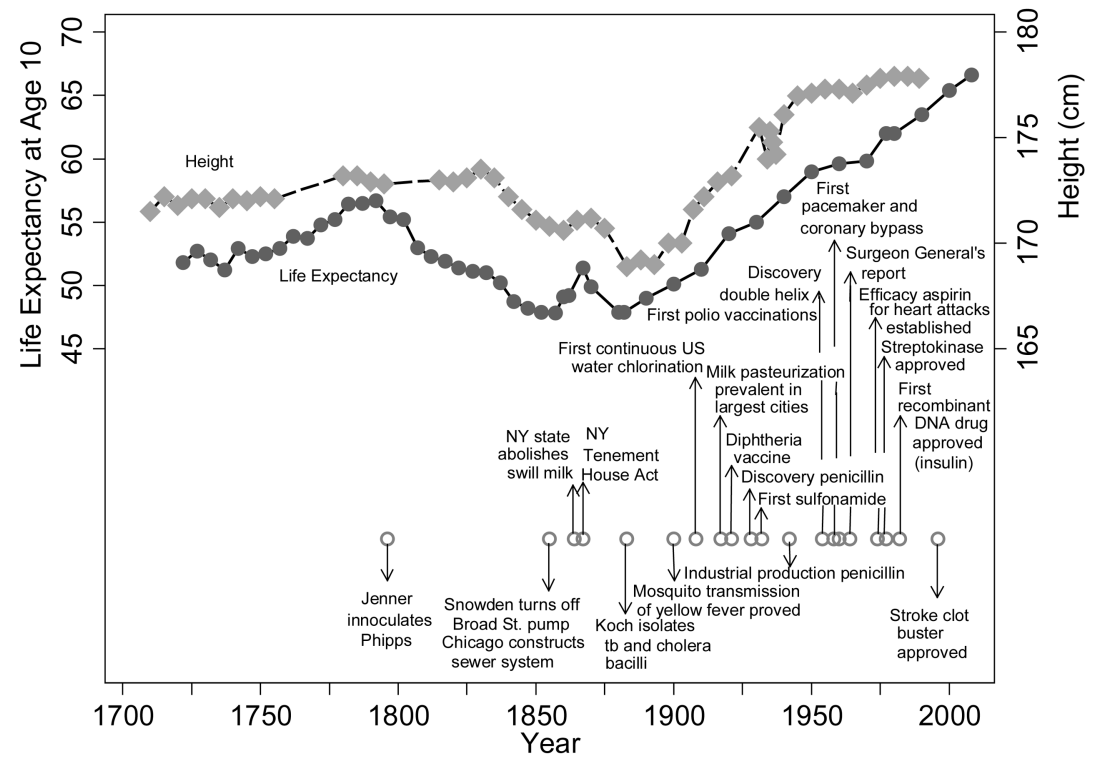

Panel B: Education and Real Per Capita GDP

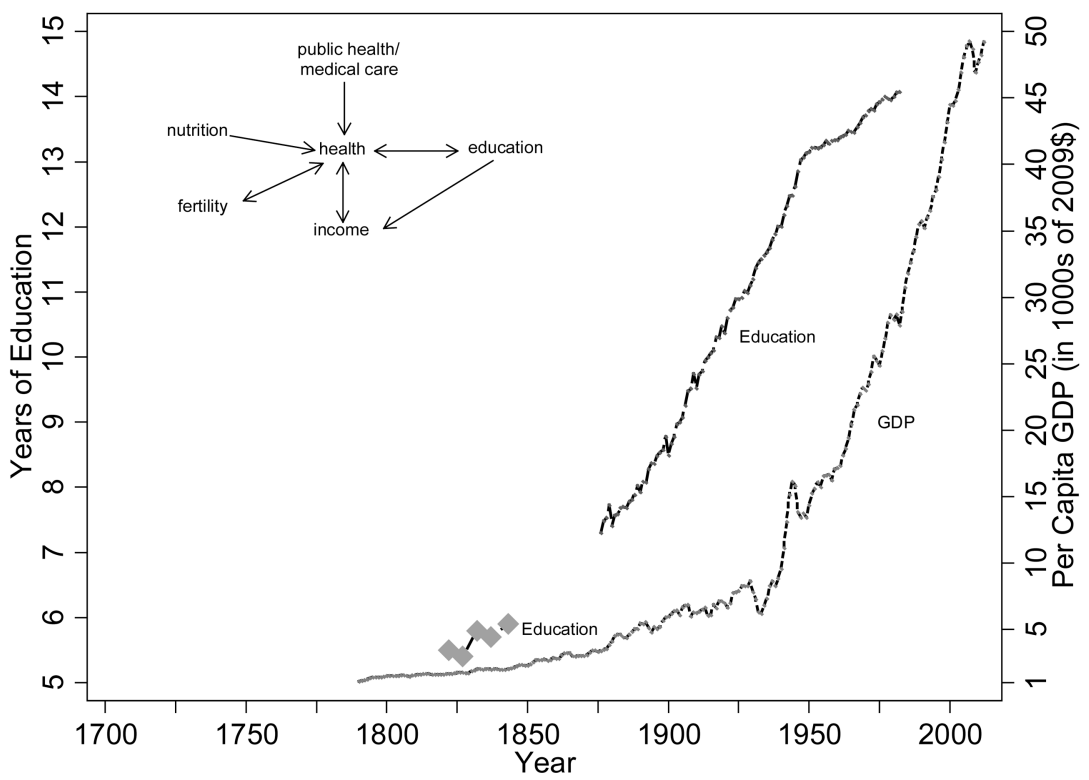

Figure 1.

The Health Transition

Sources: For Panel A see figures 2 and 3. Per Capita GDP in Panel B is from Williamson (2014). Years of education from 1876 onwards is by year of birth for the native-born and reproduces and extends Figure 1.4 from Goldin and Katz (2008: 20). I thank Goldin for providing the data. Earlier years of education are for white males who served in the Union Army and are from Bleakley et al. (forthcoming). 


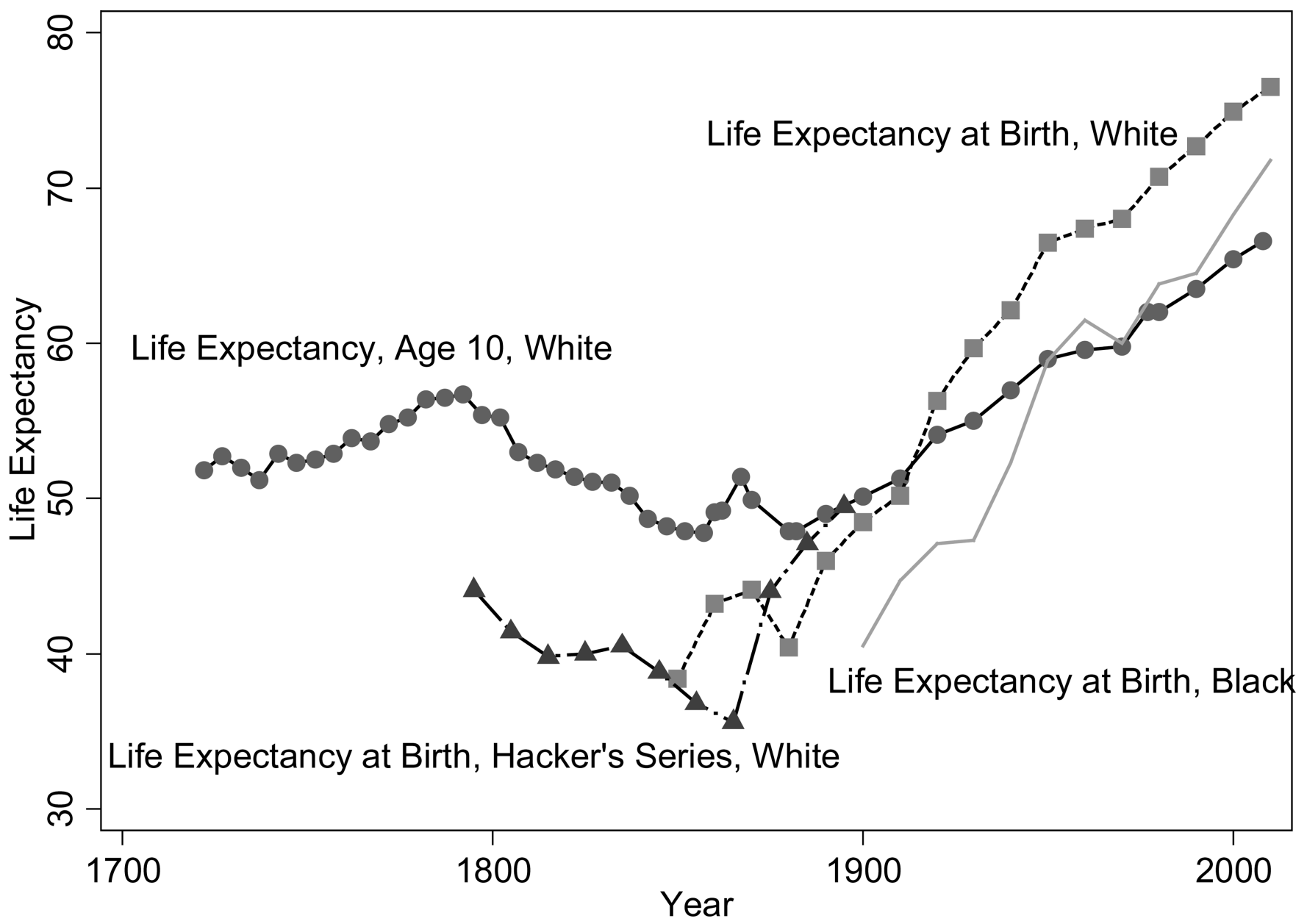

Figure 2.

Male Life Expectancy in the US, $1722-2010$

Source: Fogel (1986), Hacker (2010), and Vital Statistics data. 


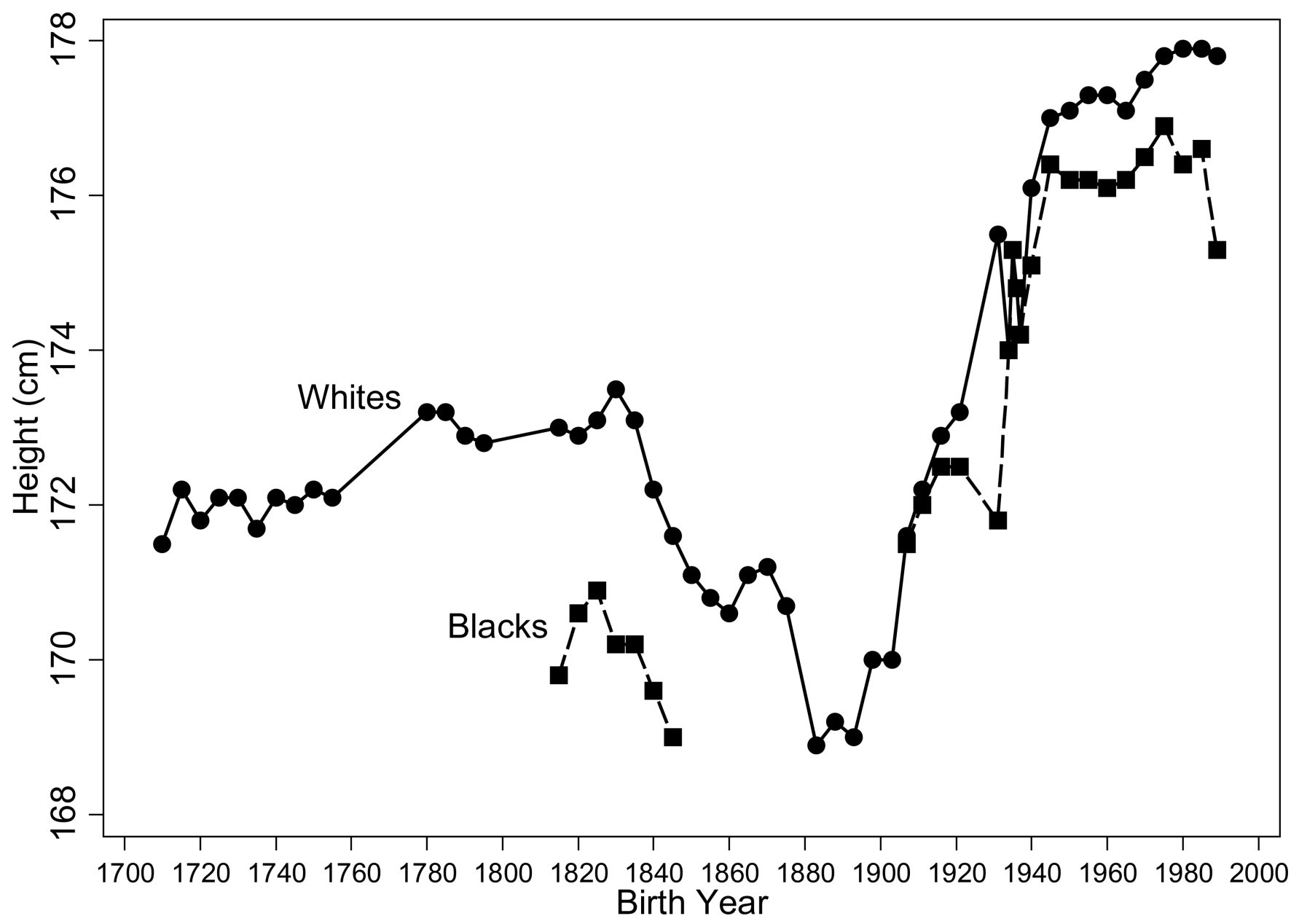

Figure 3.

Heights for US Men Born 1710-1989

Source: Bleakley et al. (forthcoming). This figure updates the white height series in Figure 2.1 in Costa and Steckel (1997), which in turn updated Fogel (1986), using the 1963-2010 NHIS and adds a height series for blacks using the Union Army records at www.uadata.org, published WWII heights, and the NHIS. Year of birth is centered at the marks. Estimates using the NHIS were adjusted to account for biases resulting from self-reporting in the NHIS. 


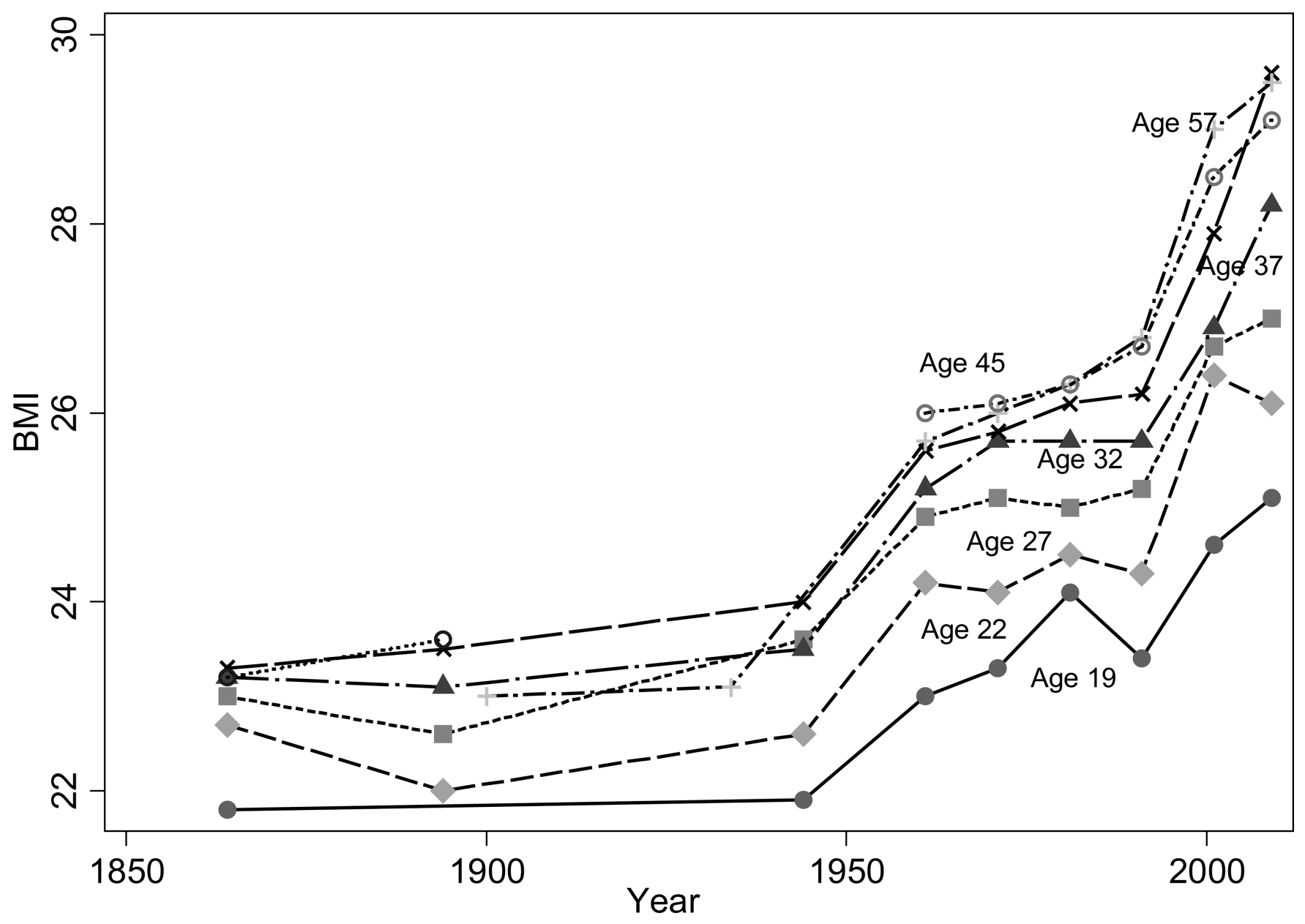

Figure 4.

Men's BMI by Age Group in the US, 1864-2009

Source: Author's calculations from the Gould sample (Costa 2004a), the Union Army sample, WWII enlistment records, and NHANES. 


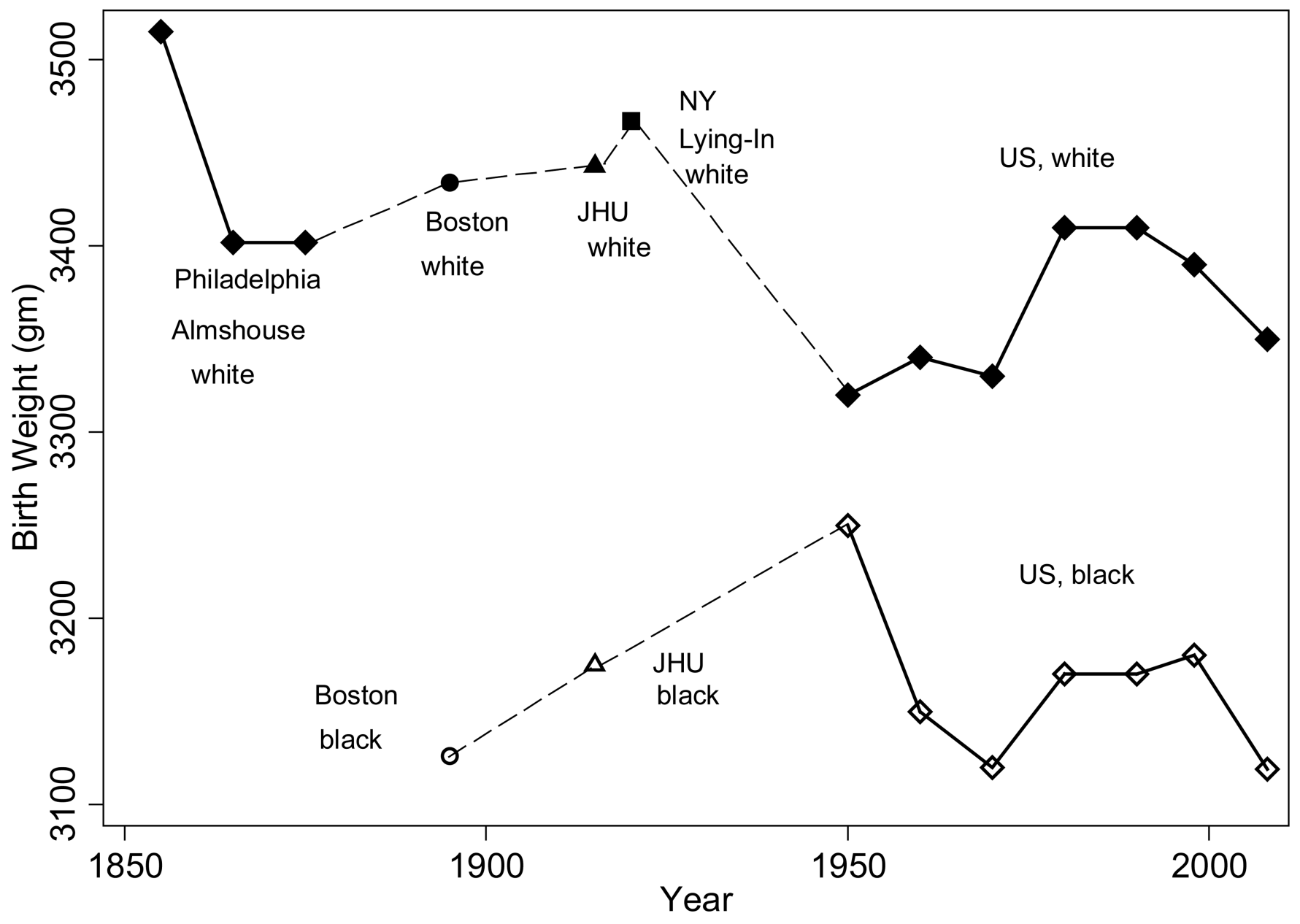

Figure 5.

US Birth Weight Trends, 1850s-2008

Source: Author's calculations from Goldin and Margo's (1989) Philadelphia Almshouse data, Ward (1993: 148-149), the records of JHU (Costa 2004b), the records of NY Lying-In (Costa 1998), published National Vital Statistics Records (for 1950), and the NCHS's 1968, 1978, 1998, and 2008 Vital Statistics Natality Data. 


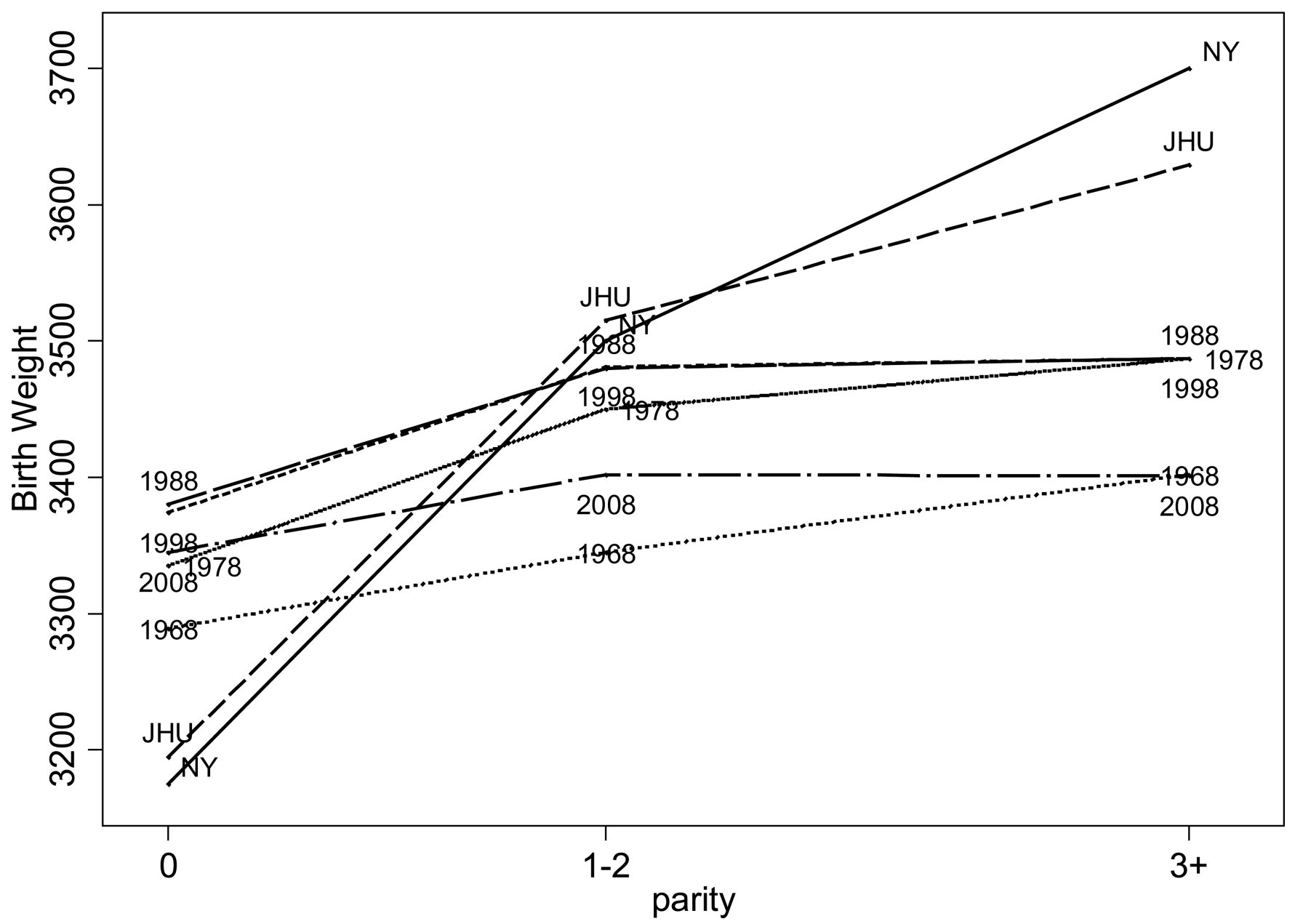

Figure 6.

Birth Weights by Parity

Source: Author's calculations from the records of New York Lying-In (Costa 1998), Johns Hopkins (Costa 2004), and NCHS's 1968, 1978, 1998, and 2008 Vital Statistics Natality Data. 


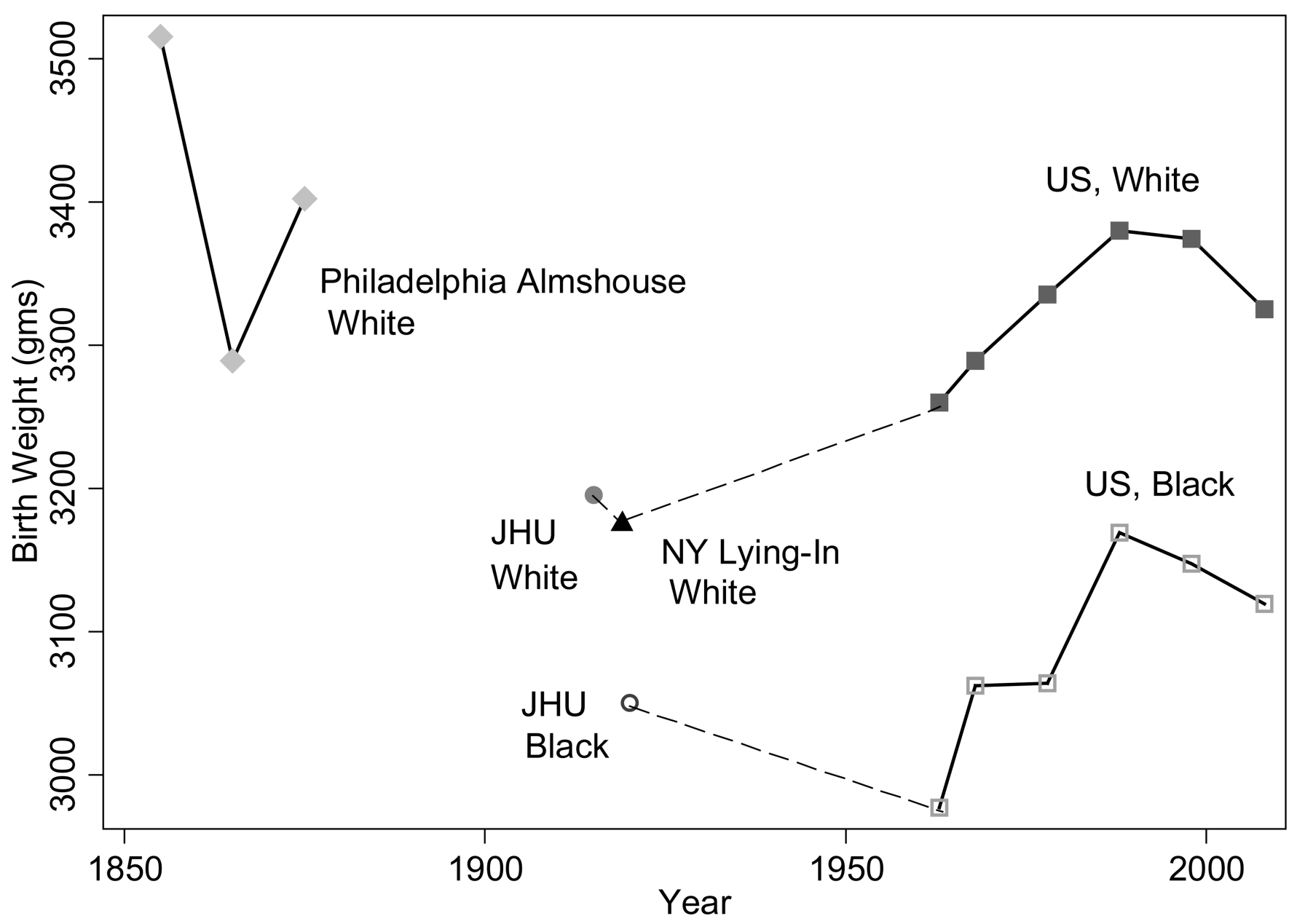

Figure 7.

US Birth Weight Trends for First Births, 1850s-2008

Source: Author's calculations from the records of the Philadelphia Almshouse (Goldin and Margo 1989), of New York Lying-In (Costa 1998), Johns Hopkins (Costa 2004), and NCHS's 1968, 1978, 1998, and 2008 Vital Statistics Natality Data. 


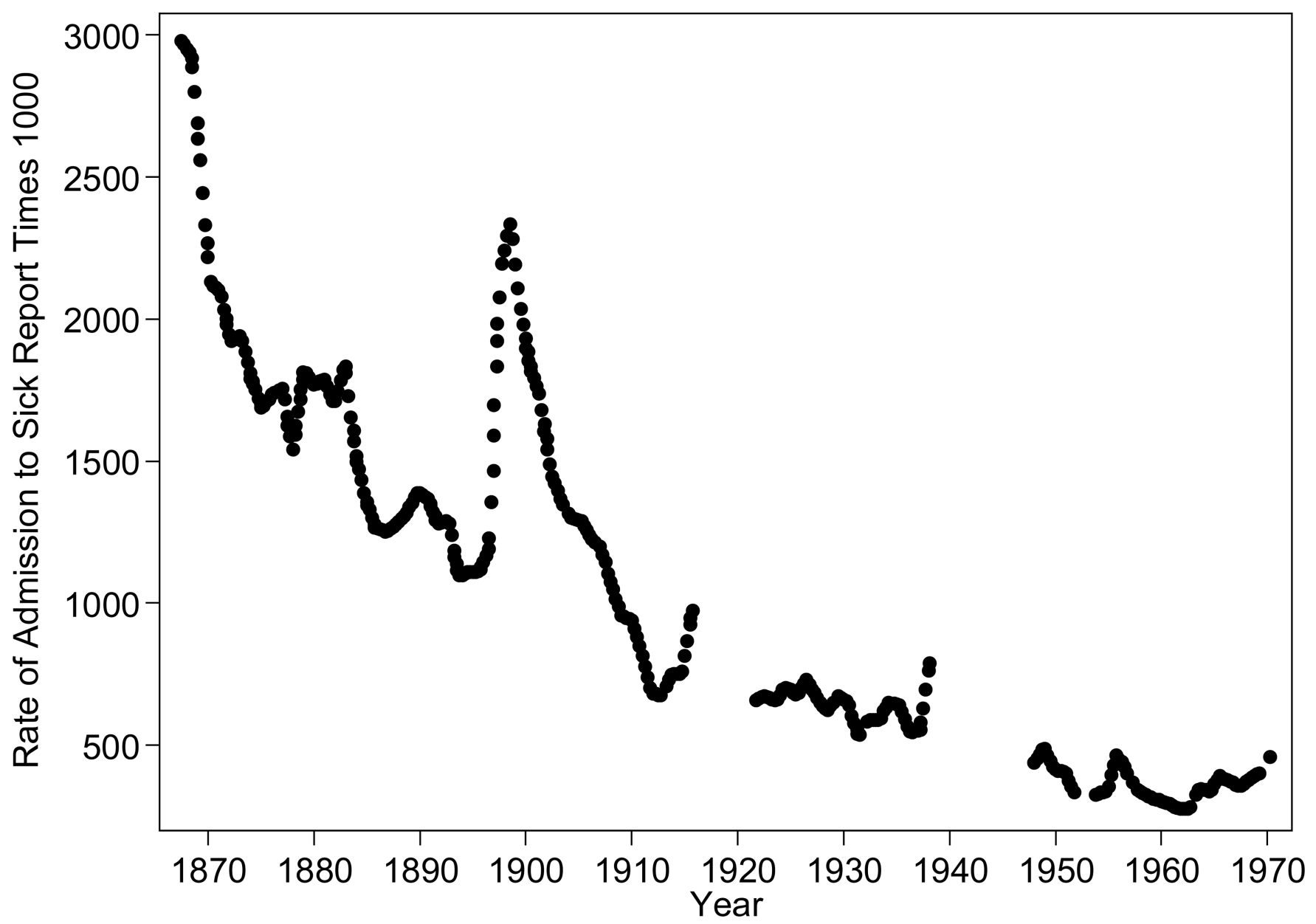

Figure 8.

Sickness Rates in the US Army, 1867-1970

Source: Reproduced from Cautero (1998) using Get Data Graph Digitizer. Cautero compiled the rate of admission from the Annual Reports of the Surgeon General for the Army. The rate of admission to sick report is the total number admitted divided by the total number of personnel. 


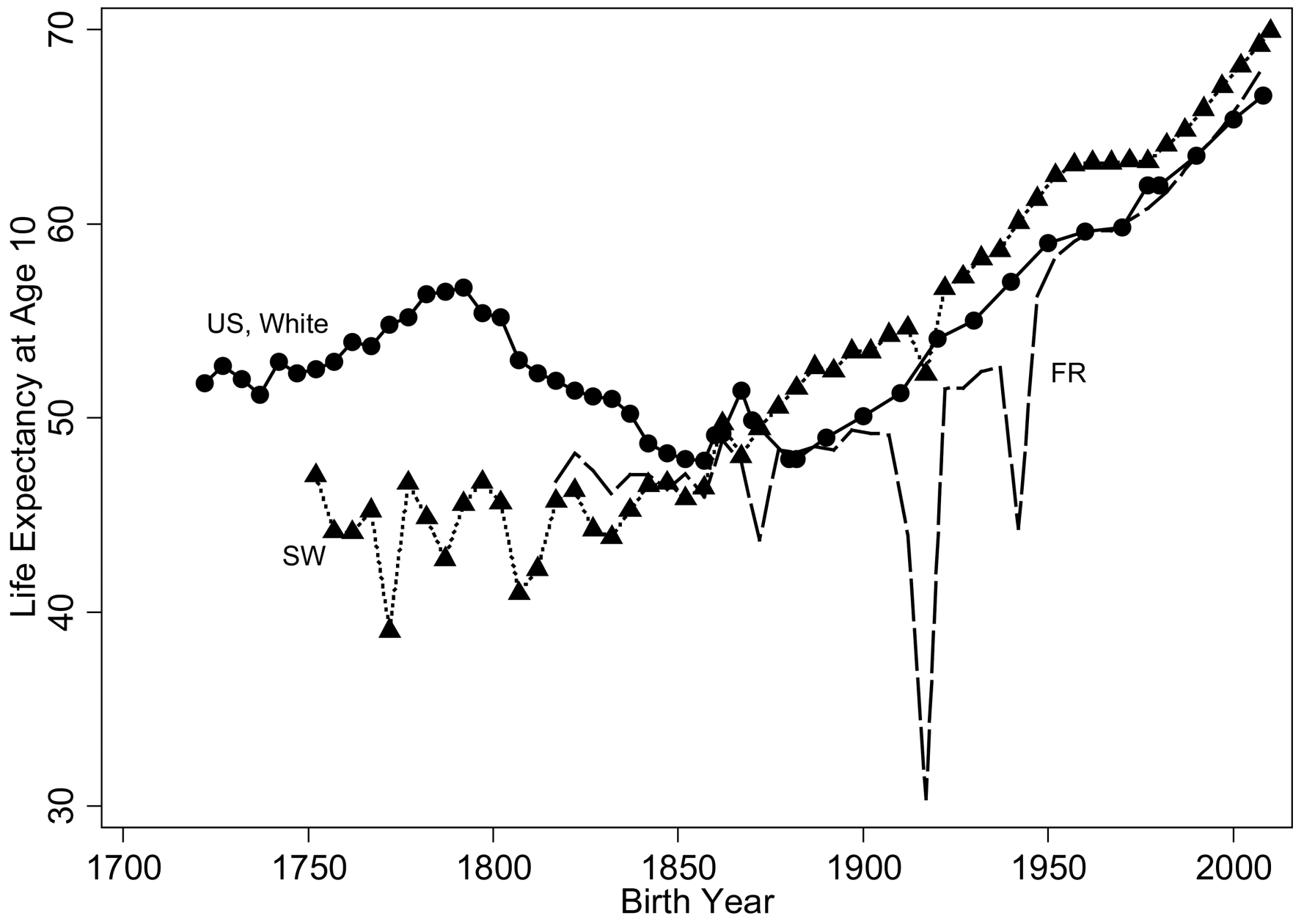

Figure 9.

Male Life Expectancy at Age 10, United States, Sweden, and France

Source: For the US, see the notes to Figure 1. Data for Sweden and France are from the

Human Mortality Database, http://www.mortality.org/ and are for period life expectancy. 


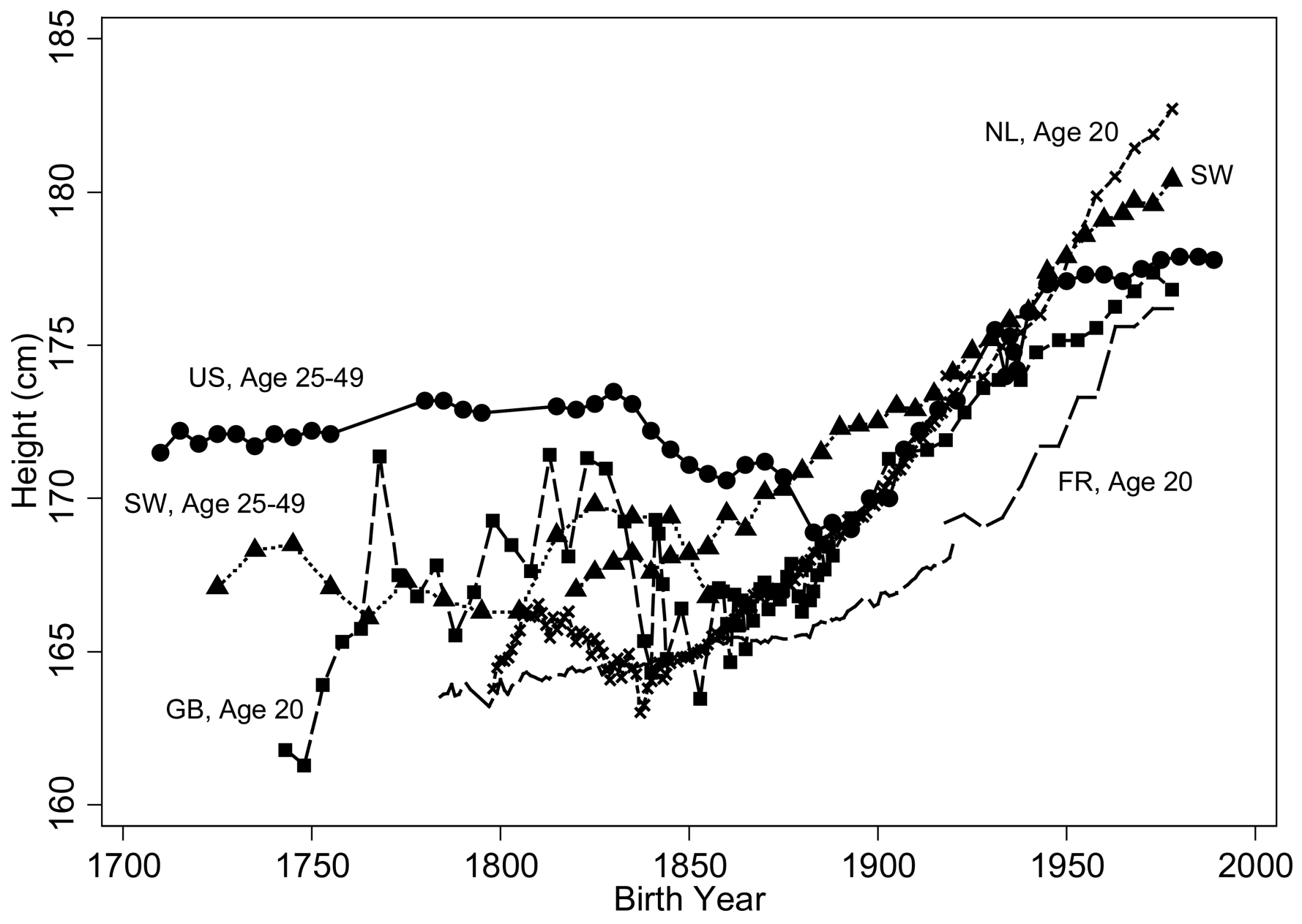

Figure 10.

Men's Heights, US, Sweden, Great Britain, the Netherlands, and France

Source: For the US, see the notes to Figure 2. The data for Sweden, age 25-49 are from Sandberg and Steckel (1987) and begin with the 1720-29 birth decade and end with the 1850-59 birth decade. The second Swedish series (SW) is from two sources. The longest running series, covering the 1820-1965 birth cohorts, is from Sandberg and Steckel (1997) and measures men at age 21 (born 1820-97), age 20 (born 1898-1929), age 19 (born 193035), and age 18 (born 1936-present). These age reductions coincide with declines in the age of maturation. This series was augmented with Hatton and Bray's (2010) series for 19681978. The series for France is based on Weir (1997) for the cohorts born 1784-1902, on Drukker and Tassenaar (1997) for the cohorts born 1902-1920, and on Hatton and Bray (2010) for the cohorts born 1923-1978. The series for Great Britain was based on Floud et al. (1990: 142-144) for the cohorts born 1743-1888 and Hatton and Bray (2010) for cohorts born 1893-1978. The series for the Netherlands was based on Drukker and Tassenaar (1997) for cohorts born 1798-1920 and on Hatton and Bray (2010) for the cohorts born 1918-1978. 


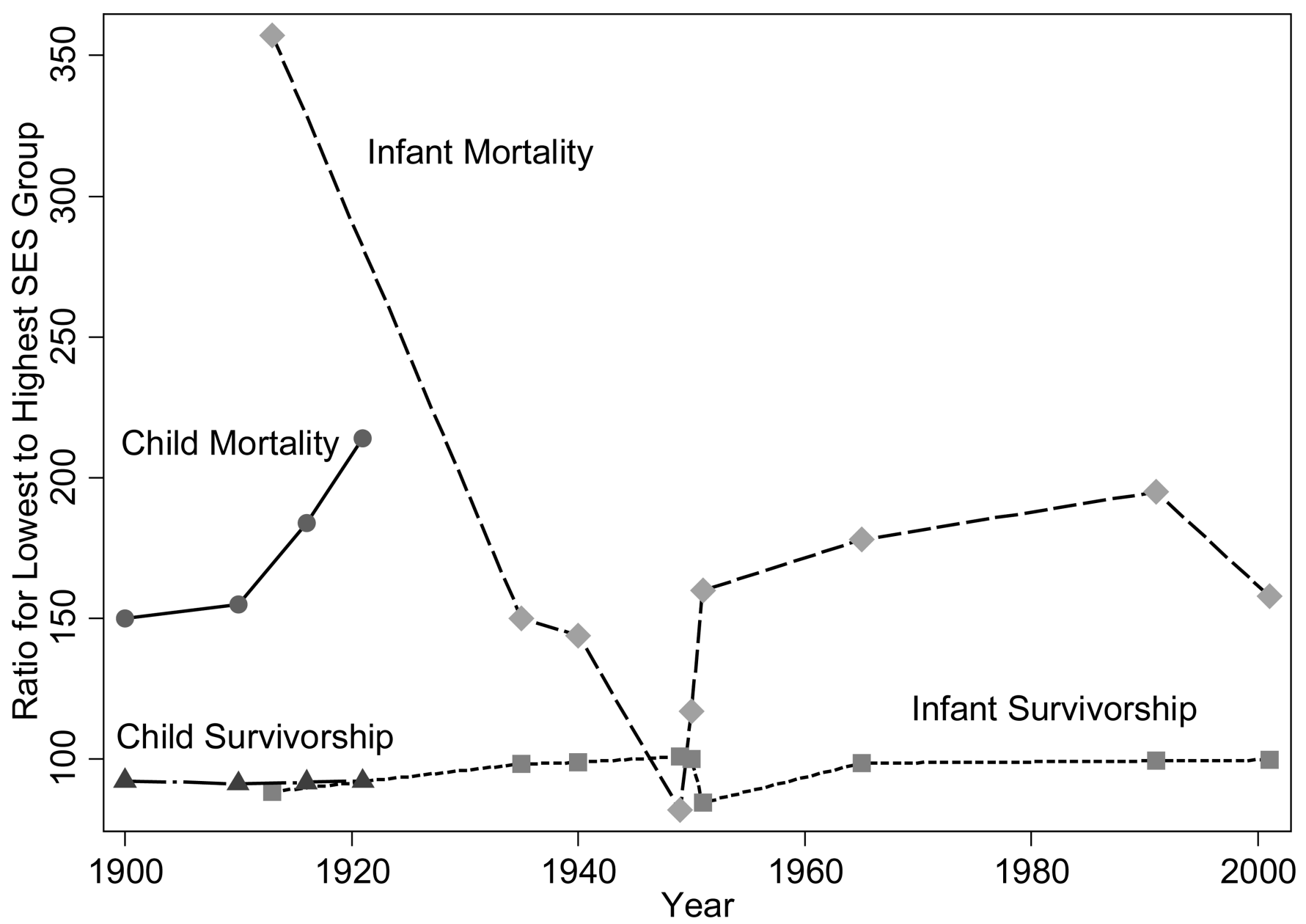

Figure 11.

Infant and Child Mortality Trends by Socioeconomic Status

Source: Haines (2010). Socioeconomic status is not consistently defined. 

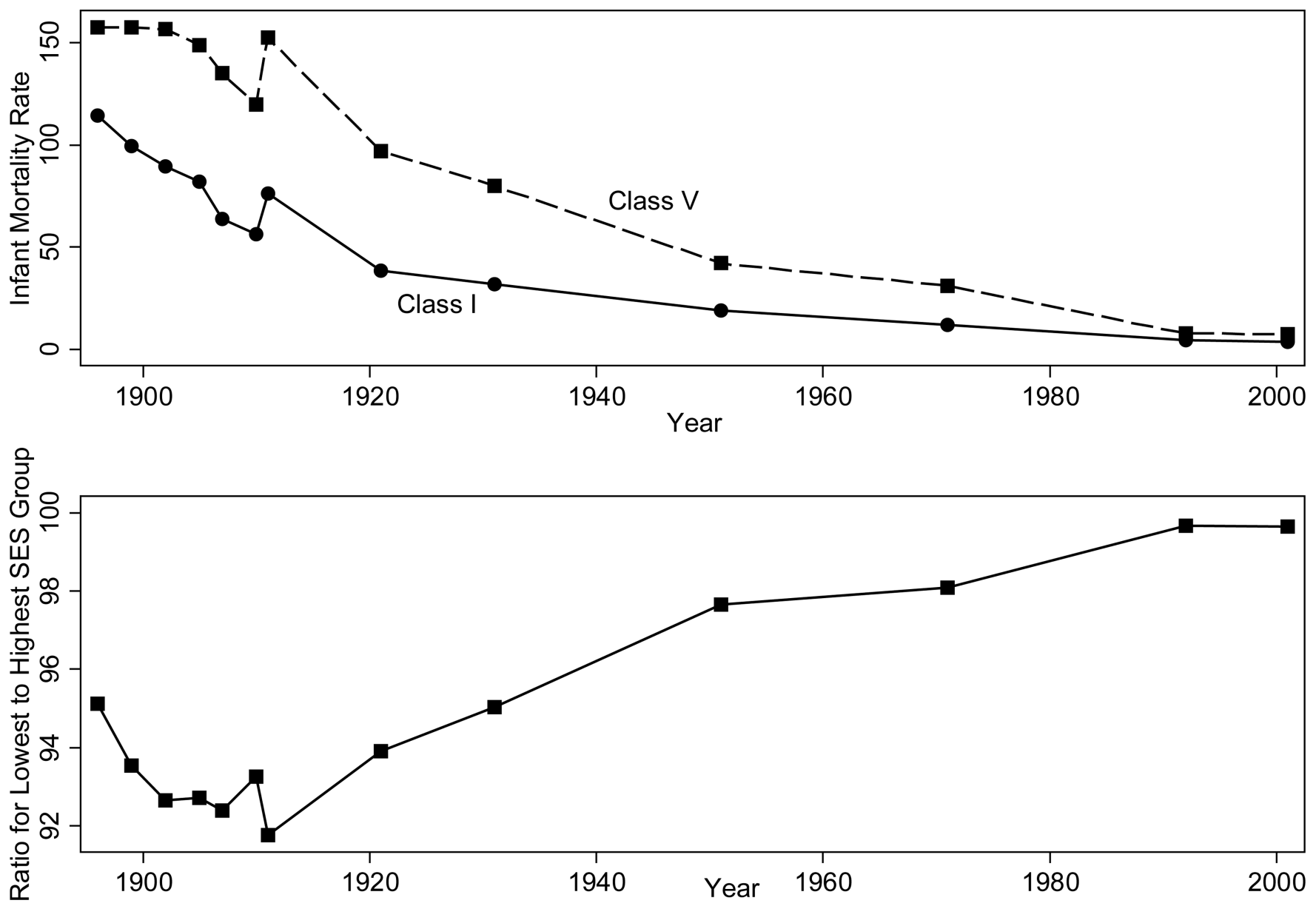

Figure 12.

Infant Mortality by Social Class, England and Wales, 1895-2001

The top panel shows infant mortality rates by father's occupation for Class I (upper and middle class) and Class V (unskilled workmen). Class V in 1921 includes unskileld textile workers, miners, and agricultural laborers. These were separate classes prior to 1921. The bottom panel shows the ratio of infant survivorship for Class V to Class I. Sources: 18951911 from Table 7.3 in Woods (2000: 264). 1921 from the Registrar General's Decennial Supplement, 1938. 1931-2001 from Table 4.3 in Floud et al. (2011: 150). 


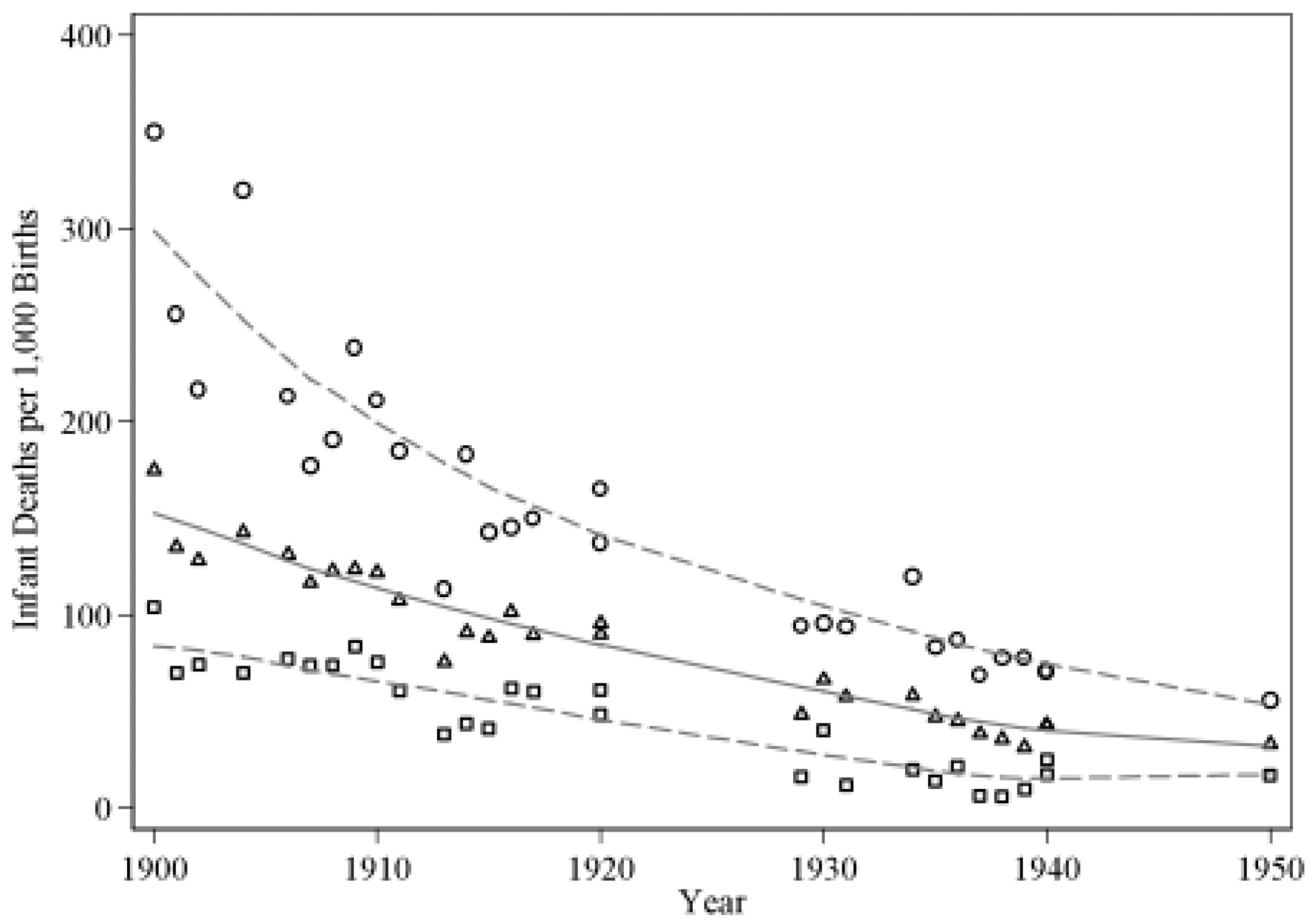

Figure 13.

Trends in Disparities by Ward in the 6 Largest US Cities, 1900-1950

Source: Floud et al. (2011: 328, Figure 6.3). The circles, triangles, and squares denote, respectively, the maximum, mean, and minimum value of infant mortality rates among wards in each city in a given year. The dashed and solid curves are lowess fit curves. This diagram shows that between 1900 and 1950 more than 80 percent of the difference in the infant mortality rate between the worst and best wards of the six large cities had disappeared. 


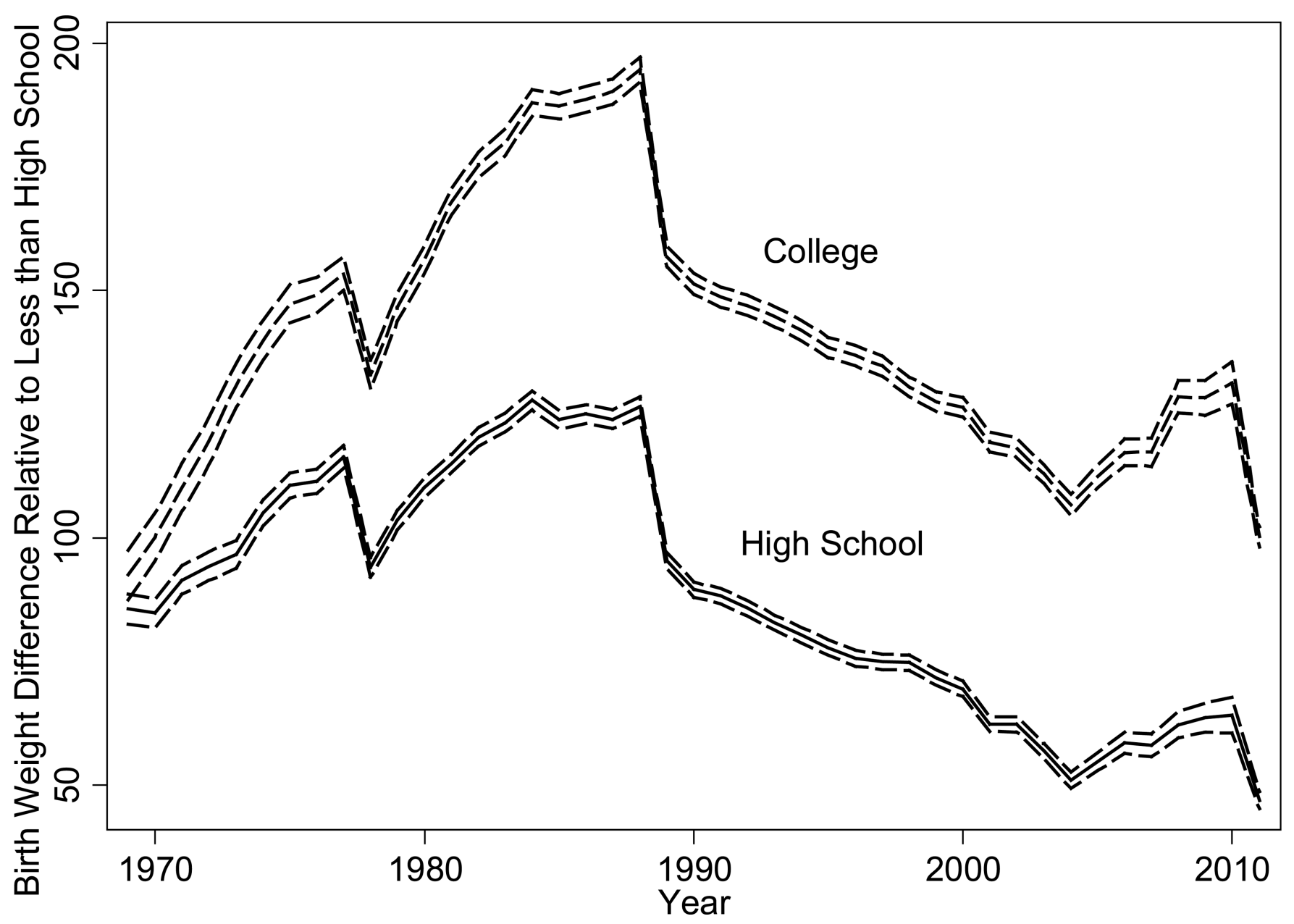

Figure 14.

The Educational Gradient in Birth Weight, Whites, 1969-2011.

Source: Author's calculations from the 1969-2011 NCHS Vital Statistics Natality Data. The figure plots the coefficients on education levels (relative to less than high school) and the confidence intervals (the dashed lines) from a regression of birth weight on educational levels controlling for age, parity, sex of the child, and gestational weeks. 


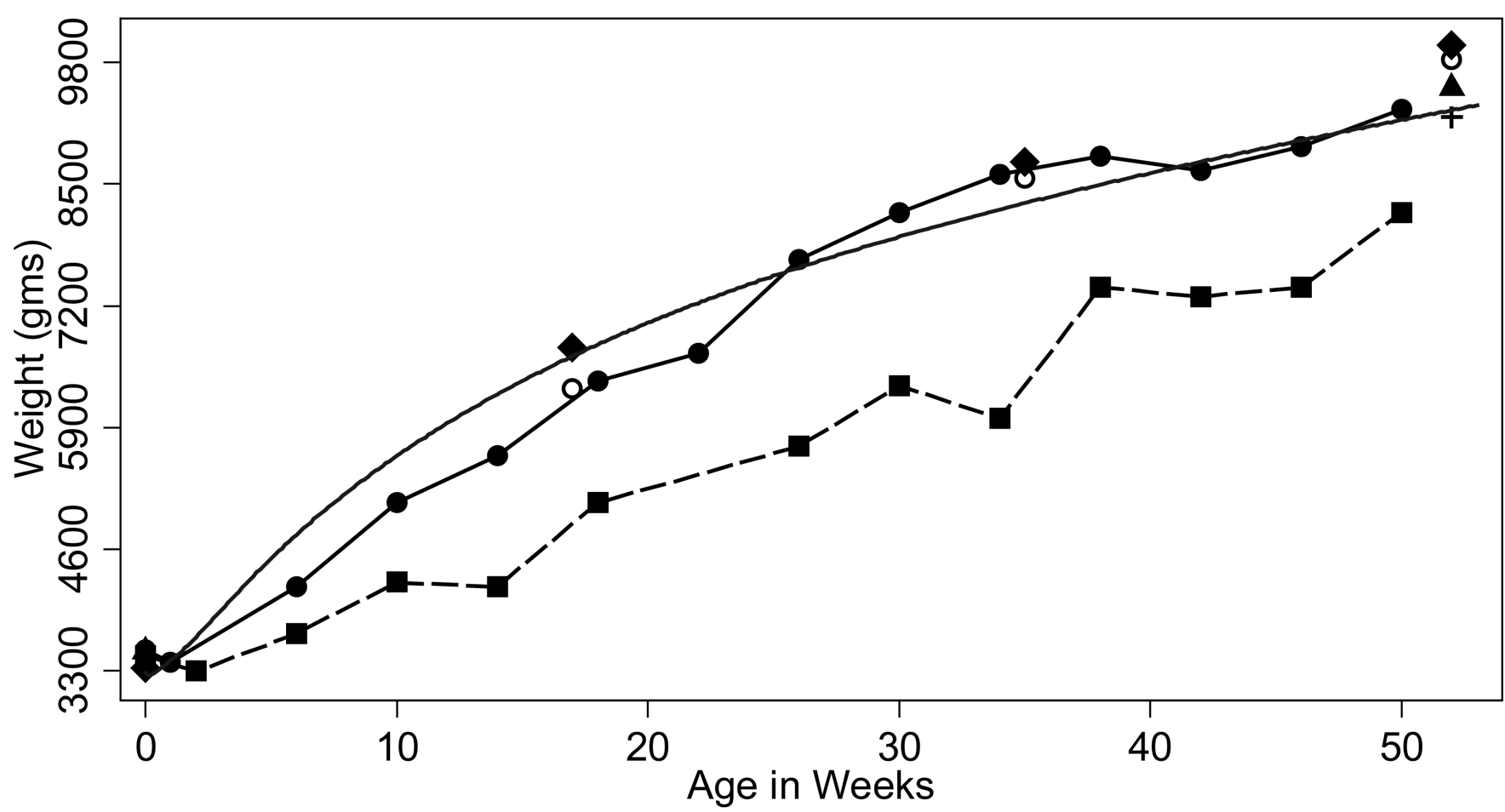

\begin{tabular}{llrl|}
$\longrightarrow$ & 5th Ave & $--\mathbf{r}--$ & Bellevue \\
$\Delta$ & JHU, white & + & JHU, black \\
& CPP, private patient & $\circ$ & CPP, welfare recipient \\
WHO, 50th Percentile & & \\
\hline
\end{tabular}

Figure 15.

Weight in the First Weeks of Life

Source: Bakwin and Bakwin (1931) and author's calculations from the records of Johns Hopkins University (JHU), 1910-19935 and the Collaborative Perinatal Project, CPP (1959-1974). 

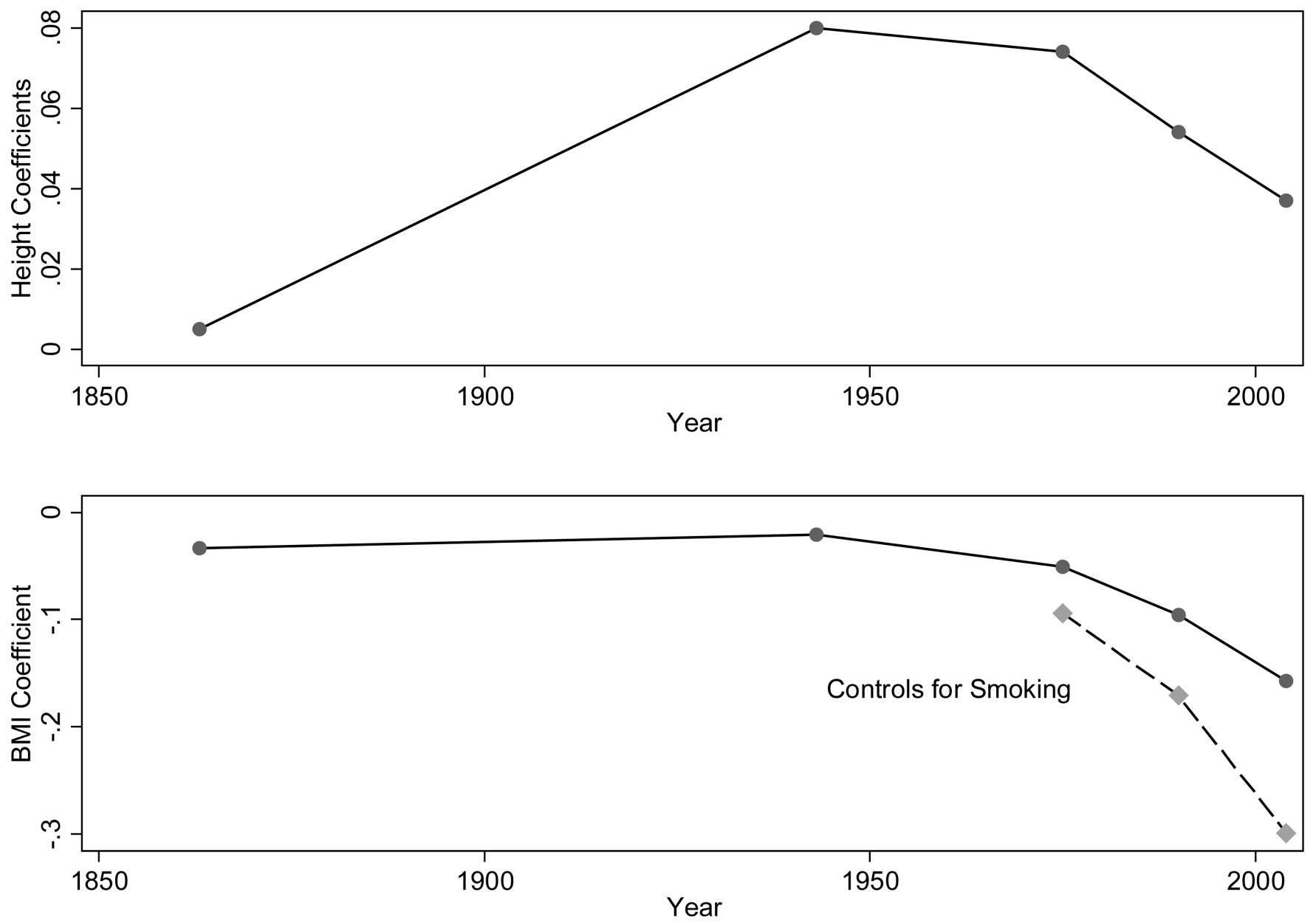

Figure 16.

The Relationship between Education, Height and BMI, White Native-Born Males

Source: Tables 2 and 3 from Bleakley et al. (forthcoming) for height coefficients and author's calculations for BMI coefficients using the Gould sample (Costa 2004a), WWII enlistment records, and NHANES. The coefficients are from regressions of years of education on height or BMI, controlling for age or cohort, region of residence, metro area, and state or place of residence. 

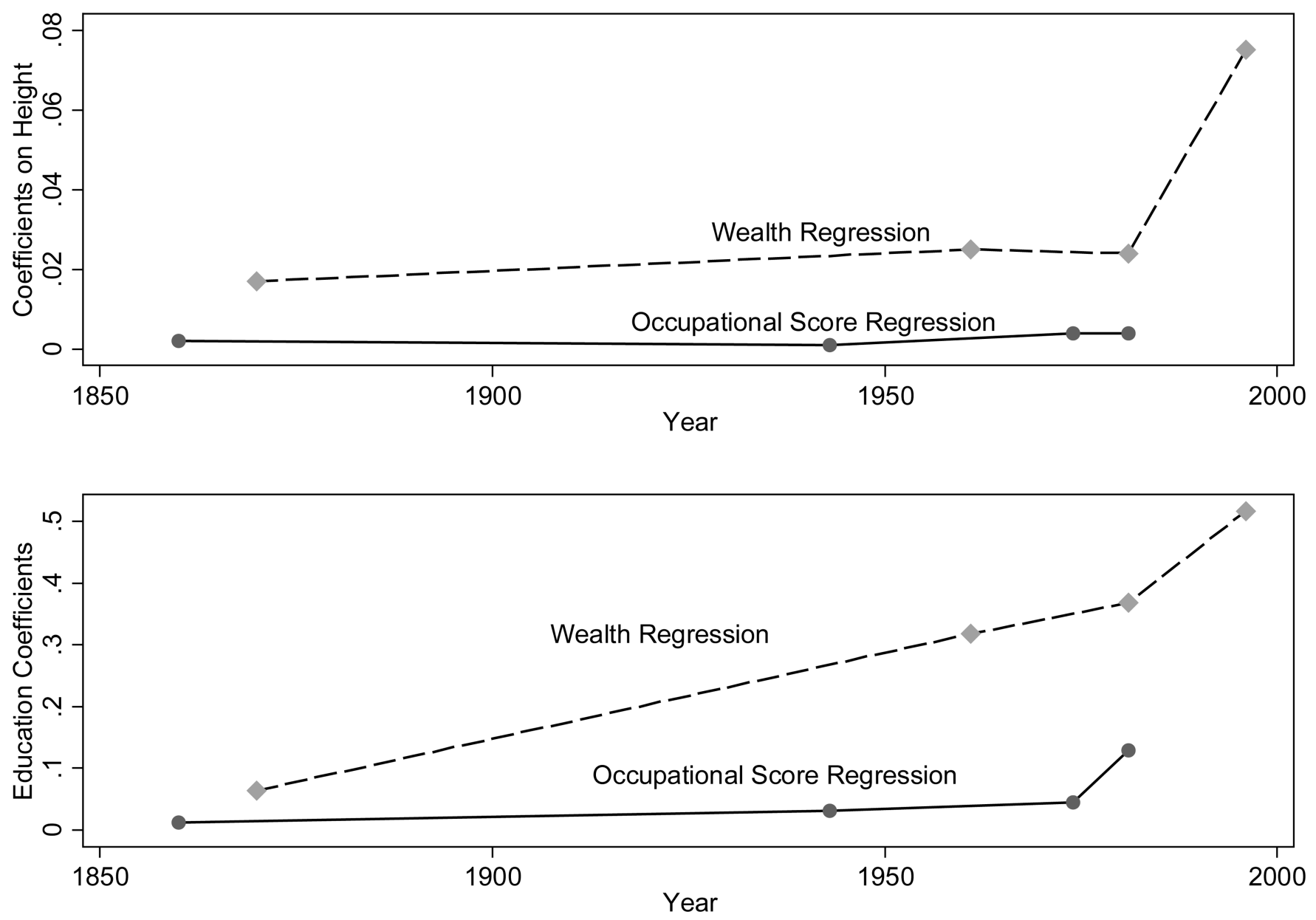

Figure 17.

The Relationship Between Height, Wealth and Occupational Ranking and BMI, Wealth and Occupational Ranking, White Men

Source: Tables 4, 5, and 6 in Bleakley et al. (forthcoming). The coefficients are from a regression of wealth or occupational ranking on height and education controlling for age and/or cohort, year of survey (when applicable), foreign birth, and region of residence. 

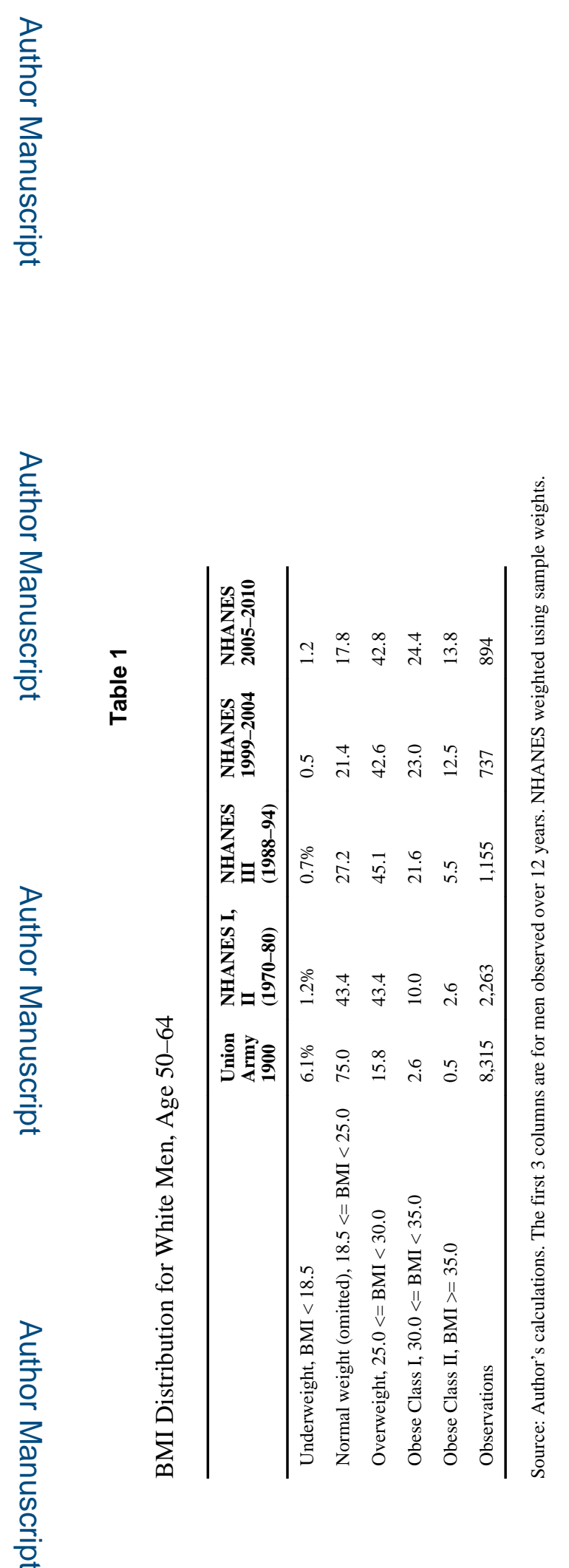

J Econ Lit. Author manuscript; available in PMC 2015 September 21. 
Table 2

BMI and Mortality: Changing Relationship White Men, Age 50-64, Observed for 12 Year Period

\begin{tabular}{|c|c|c|c|}
\hline & $\begin{array}{l}\text { Union } \\
\text { Army } \\
1900\end{array}$ & $\begin{array}{l}\text { NHANES I, } \\
\text { II } \\
\text { (1970-80) }\end{array}$ & $\begin{array}{l}\text { NHANES } \\
\text { III } \\
(\mathbf{1 9 8 8 - 9 4 )}\end{array}$ \\
\hline & $\begin{array}{l}\text { Hazard } \\
\text { Ratio }\end{array}$ & $\begin{array}{l}\text { Hazard } \\
\text { Ratio }\end{array}$ & $\begin{array}{l}\text { Hazard } \\
\text { Ratio }\end{array}$ \\
\hline Underweight, BMI $<18.5$ & $1.364 * * *(0.086)$ & $1.287(0.357)$ & $2.208(2.696)$ \\
\hline Normal weight (omitted), $18.5<=\mathrm{BMI}<25.0$ Overweight, $25.0<=\mathrm{BMI}<30.0$ & $1.233 * * *(0.053)$ & $0.961(0.093)$ & $0.907(0.213)$ \\
\hline Obese Class I, $30.0<=$ BMI $<35.0$ & $1.280 * * *(0.123)$ & $1.738 * *(0.226)$ & $1.047(0.300)$ \\
\hline Obese Class II, BMI >= 35.0 & $2.449 * * *(0.457)$ & $1.648(0.493)$ & $1.863 * * *(0.024)$ \\
\hline Observations & 8,315 & 2,263 & 1,155 \\
\hline
\end{tabular}

Source: Author's calculations from a Cox proportional model. Standard errors in parentheses. NHANES regressions control for present and past smoking status. All regressions control for age. 


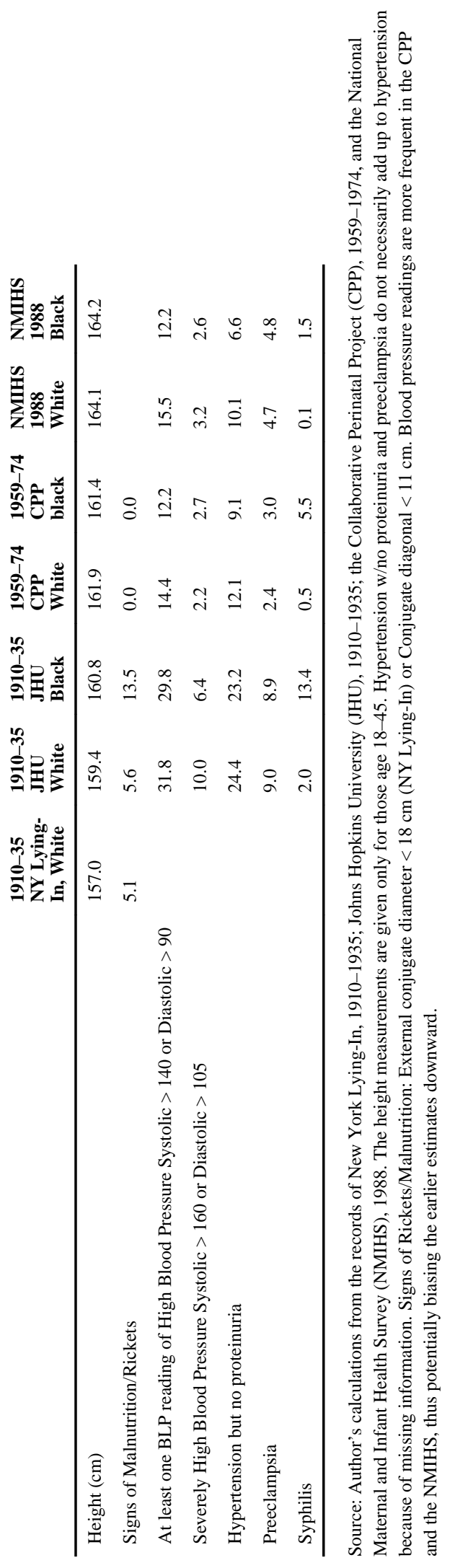

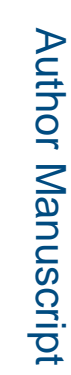

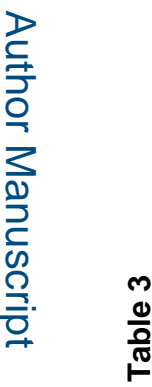



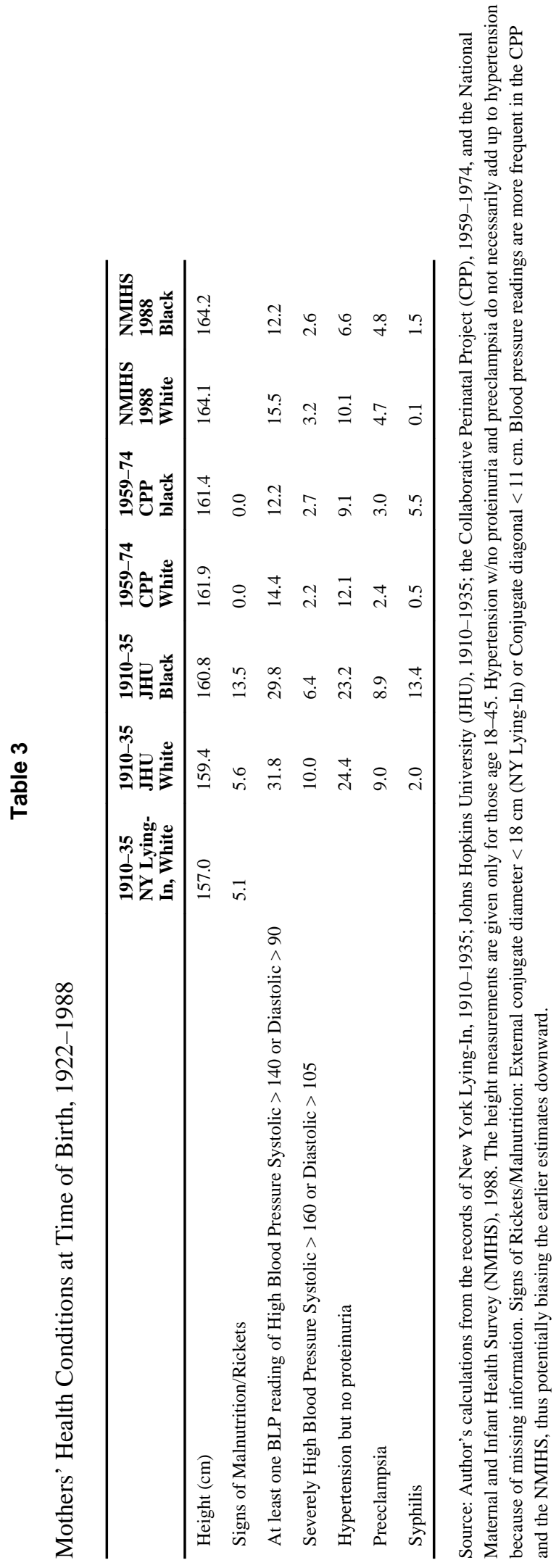

J Econ Lit. Author manuscript; available in PMC 2015 September 21. 


\section{Table 4}

\begin{tabular}{|c|c|c|c|c|c|}
\hline \multirow{7}{*}{ 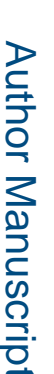 } & \multicolumn{5}{|c|}{ Men's Hypertension Prevalence Rates } \\
\hline & & & Whites & & Blacks \\
\hline & Age & WWII & 1988-91 & WWII & 1988-91 \\
\hline & $18-19$ & $16.9 \%$ & $0.0 \%$ & $18.2 \%$ & $0.9 \%$ \\
\hline & $20-24$ & 20.7 & 3.0 & 22.6 & 5.5 \\
\hline & $25-29$ & 26.0 & 4.2 & 28.6 & 10.0 \\
\hline & $30-34$ & 29.8 & 11.2 & 31.9 & 12.5 \\
\hline & $35-37$ & 32.6 & 11.1 & 33.9 & 15.6 \\
\hline
\end{tabular}

Source: Compiled from the tables in Karpinos (1958). 


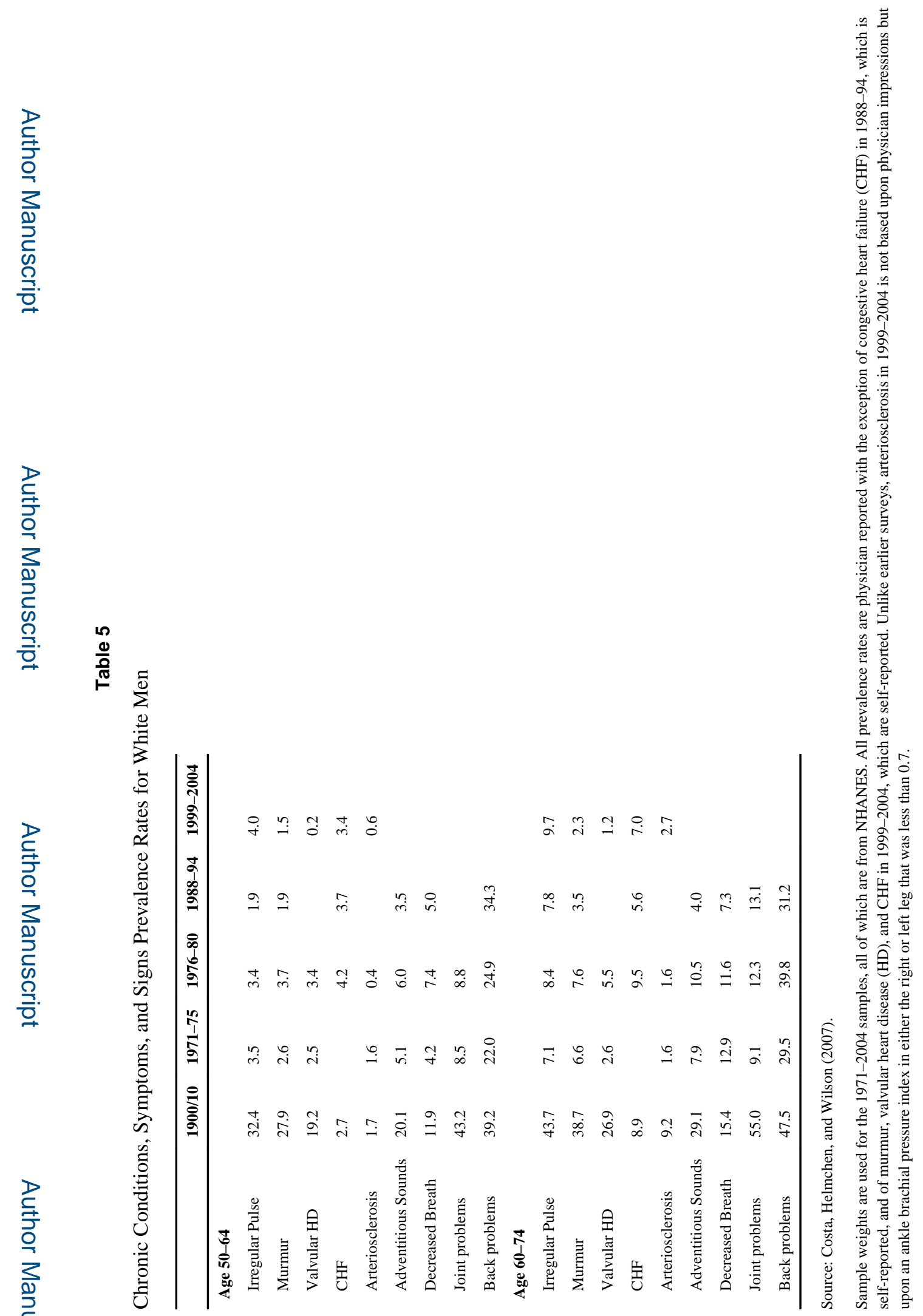



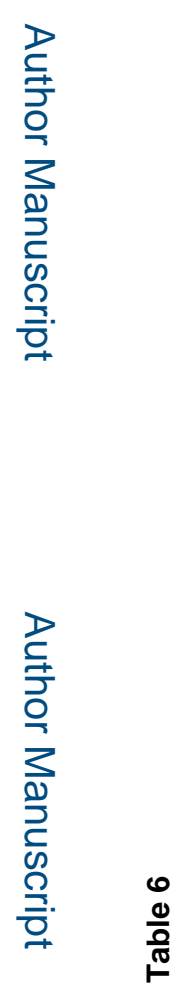

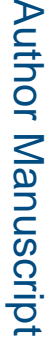

$\sum_{\frac{\pi}{0}}^{\frac{\pi}{0}}$

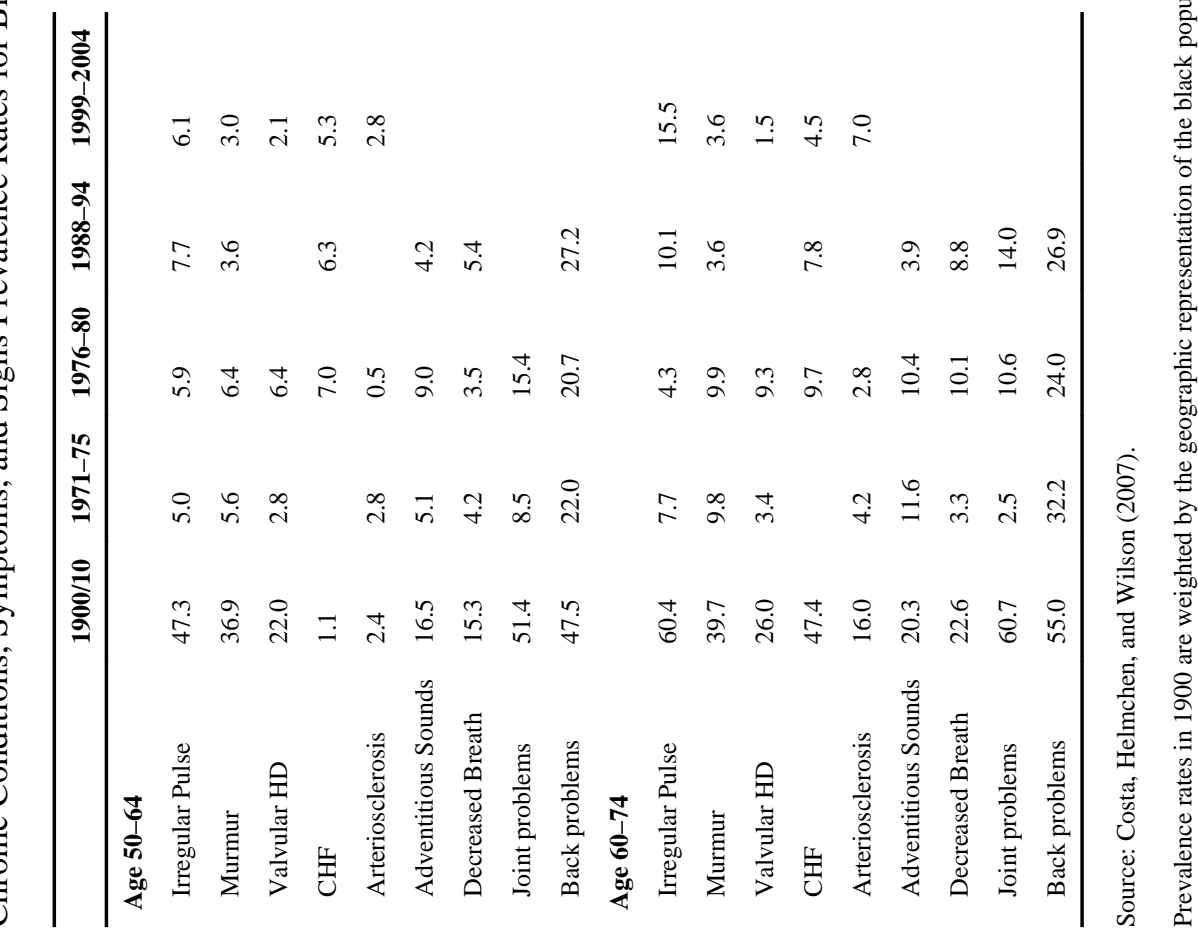

J Econ Lit. Author manuscript; available in PMC 2015 September 21. 


\section{Table 7}

Birth Weights by Socioeconomic Status

\begin{tabular}{llll}
\hline & First Birth & $\begin{array}{l}\text { Higher } \\
\text { Order }\end{array}$ \\
\hline \multirow{2}{*}{1931} & $5^{\text {th }}$ Ave, full-term & 3432 & 3588 \\
& Bellevue & 3331 & 3536 \\
\multirow{2}{*}{$1959-74$} & CPP, private & 3307 & 3354 \\
& CPP, welfare & 3336 & 3350 \\
\hline
\end{tabular}

Source: Stewart (1943) and author's calculations from the Collaborative Perinatal Project. Restricted to full-term, "normal" births. 
Table 8

Effect of Education on 12 Year Mortality Rates

\begin{tabular}{|c|c|c|c|c|}
\hline & $\begin{array}{l}\text { Union } \\
\text { Army }\end{array}$ & $\begin{array}{l}\text { NHANES } \\
\text { I (1971- } \\
\text { 1975) }\end{array}$ & $\begin{array}{l}\text { NHANES } \\
\text { II } \\
(\mathbf{1 9 7 6 - 8 0 )}\end{array}$ & $\begin{array}{l}\text { NHANES } \\
\text { III } \\
(\mathbf{1 9 8 8 - 9 4 )}\end{array}$ \\
\hline & $\begin{array}{l}\text { Hazard } \\
\text { Ratio }\end{array}$ & $\begin{array}{l}\text { Hazard } \\
\text { Ratio }\end{array}$ & $\begin{array}{l}\text { Hazard } \\
\text { Ratio }\end{array}$ & $\begin{array}{l}\text { Hazard } \\
\text { Ratio }\end{array}$ \\
\hline \multicolumn{5}{|l|}{ Without controls for smoking } \\
\hline Years Education & $0.989(0.025)$ & $0.969 * * *(0.007)$ & $0.956 * * *(0.010)$ & $0.948^{* * *} *(0.008)$ \\
\hline \multicolumn{5}{|c|}{ With controls for ever and current smoker } \\
\hline Years Education & & $0.977 *(0.013)$ & $0.965 * * *(0.010)$ & $0.964 * * *(0.009)$ \\
\hline \multicolumn{5}{|c|}{ With controls for ever and current smoker } \\
\hline And years smoked Years Education & & & & $0.979 * *(0.010)$ \\
\hline
\end{tabular}

Source: Bleakley et al. (forthcoming). Hazard ratios are from Gompertz models examining 12-year mortality rates among Union Army veterans age 55-74 in 1900 and men of the same age first observed in the NHANES surveys. Additional controls for the Union Army sample are age in 1900, $\log$ of population in the city of enlistment, an 1860 census dummy, and state of enlistment fixed effects. Additional controls for NHANES are age at the time of the survey, a metro dummy, region of residence fixed effects in NHANES I and II, and state of residence fixed effects in NHANES III. Sample weights were used for NHANES III. 
Table 9

Sibling Correlations at Birth

\begin{tabular}{llll}
\hline & Birth weight & Birth length & Gestational weeks \\
\hline JHU, whites 1895-1935 cohort & $0.466(0.061)$ & $0.213(0.075)$ & $0.124(0.068)$ \\
CPP, whites 1955-66 cohort & $0.482(0.005)$ & & $0.225(0.006)$ \\
Norway 1967-2004 cohort & $0.506(0.003)$ & $0.408(0.004)$ & $0.316(0.004)$ \\
PSID 1985-97 cohort & $0.500(0.019)$ & & $0.377(0.019)$ \\
JHU, blacks 1895-1935 cohort & $0.447(0.052)$ & $0.242(0.055)$ & $0.115(0.045)$ \\
CPP, blacks 1955-66 cohort & $0.424(0.005)$ & & $0.155(0.006)$ \\
\hline
\end{tabular}

Source: JHU and CPP indicate author's calculations from the records of Johns Hopkins University Hospital (see Costa 2004) and the Collaborative Perinatal Project using Restricted Maximum Likelihood (REML). Estimates from the PSID are from Mazumder (2004) and for Norway from Lunde et al. (2007). All estimates are for full-term, singleton births. 


\section{Table 10}

Brother-Brother Adult Height Correlations Among Whites

Union Army, 1861-65

World War II, 1939-45

PSID

(1812-1844 Cohort) (1909-1924 Cohort)

(1959-1968 Cohort)

All correlations are estimated using Restricted Maximum Likelihood (REML). Standard errors are in parentheses. I thank John Parman for estimating the WWII correlation. The PSID estimates are from Mazumder (2004). 


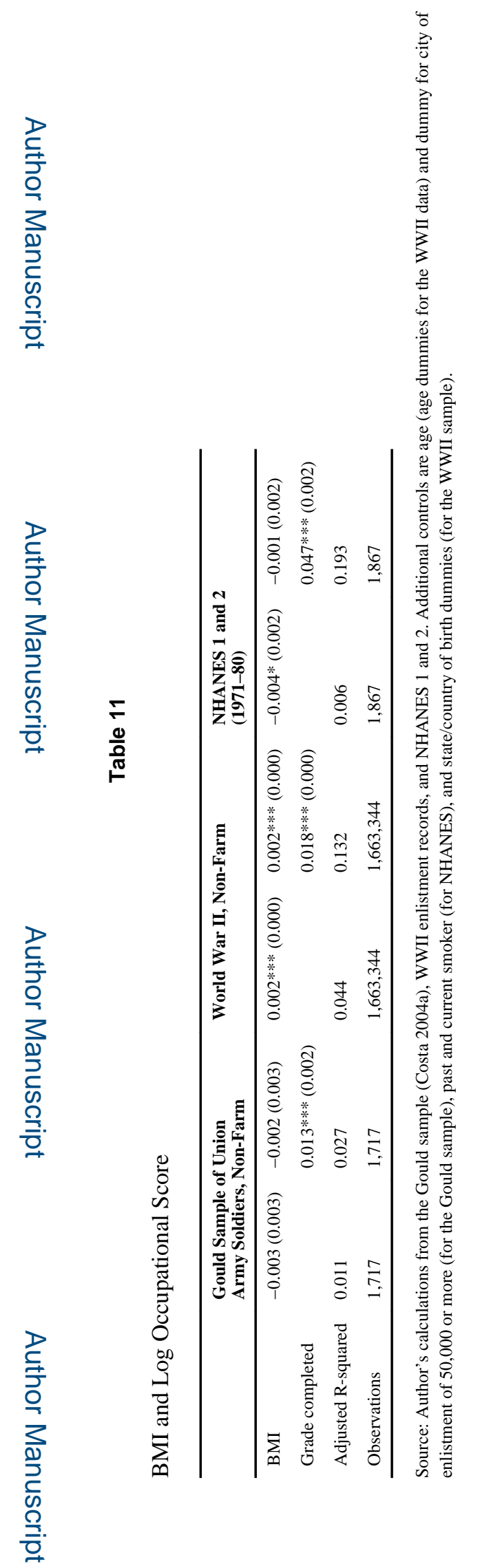

J Econ Lit. Author manuscript; available in PMC 2015 September 21. 